\title{
Trace element distribution and enrichment patterns of Ediacaran-early Cambrian, Ziyang selenosis area, Central China: constraints for the origin of Selenium
} Jie Long ${ }^{\mathrm{a}, \mathrm{b}}$, Kunli Luo ${ }^{\mathrm{a}, \mathrm{b}}$ *

${ }^{a}$ Institute of Geographic Sciences and Natural Resources Research, Chinese Academy of Sciences, Beijing 100101

${ }^{\mathrm{b}}$ University of Chinese Academy of Sciences, Beijing 100049

*Correspondence to: luokl@igsnrr.ac.cn \& kunliluo@sohu.com

Abstract:

Ziyang County is one of the two major regions in Central China exposed to selenium (Se) poisoning. To understand the origin of anomalous Se enrichment strata of the Ediacaran-early Cambrian period (ca. 635-520 Ma) in the area of Ziyang affected by selenosis, major and trace elements were analyzed for 468 samples collected from the Lujiaping Formation in Ziyang County, Central China.

Se is the most highly enriched trace element in the Lujiaping Formation of the Ediacaran-early Cambrian period. Selenium concentrations vary from 0.03 to 303 ppm, with an average of $16 \mathrm{ppm}$, or more than 324 times the concentration found in the upper continental crust. The average Se content of Bed 6 (approximately $63 \mathrm{~m}$ thick) is the highest, at $49.20 \mathrm{ppm}(1.45-154 \mathrm{ppm})$. The Lujiaping Formation is highly enriched in $\mathrm{Cd}(\times 53), \mathrm{S}(\times 31)$, Mo $(\times 22)$ and As $(\times 13)$, compared to the upper continental crust. It is slightly enriched in $\mathrm{V}(\times 8.07), \mathrm{Ba}(\times 7.65), \mathrm{Ga}(\times 7.24), \mathrm{Zn}$ (×7.22), U (×5.43), $\mathrm{Cu}(\times 4.02), \mathrm{Bi}(\times 2.55), \mathrm{Tl}(\times 2.16), \mathrm{Ni}(\times 1.75), \mathrm{P}(\times 1.03)$, and depleted in $\mathrm{Pb}$ (0.97), $\mathrm{Cr}$ (0.96), Sr (0.81), Li (0.79), In (0.69), Sc (0.69), Be (0.38), Cs (0.36), Co (0.30), Rb (0.29), and Th (0.27).

All $\mathrm{Eu} / \mathrm{Eu}^{*}$ for the forty anomalous Se-enrichment samples $(\mathrm{Se}=42-303 \mathrm{ppm})$ of the $1^{\text {st }}$ Member $(1.09-2.09$, average $=a v g=1.40), 2^{\text {nd }}$ Member $(1.20-1.38$, avg=1.29), $3^{\text {rd }}$ Member $\left(1.12-4.00\right.$, avg=2.38) and $4^{\text {th }}$ Member $(2.51-4.48$, avg=3.56), show positive $\mathrm{Eu}$ anomalies and an increasing trend upward. However, $\mathrm{Eu} / \mathrm{Eu}^{*}$ of two samples are 0.90 (HSBY324, Bed 4 of $1^{\text {st }}$ Member) and 0.95 (HSBY401, Bed 6 of $1^{\text {st }}$ Member), which indicate that they are characterized by hydrothermal sediments, except HSBY324 and HSBY401 of $1^{\text {st }}$ Member. Based on these elements' geochemical and petrographic characteristics, we conclude that these samples are of hydrothermal origin. There is also a strong positive correlation between $\mathrm{Se}$ and $\mathrm{Ba}$ $\left(R_{\mathrm{Se}-\mathrm{Ba}}=0.738^{* *}, \mathrm{n}=40\right)$. In three point $\mathrm{X}$-ray energy spectrometric analysis of black shale mineral anomalous Se-enrichment samples (HSBY601), the nor.C measurements of $\mathrm{Ba}$ (L Series) are 55.50 wt.\%, 54.94 wt.\% and 27.20 wt.\%, respectively, with the corresponding Atom. $\mathrm{C}$ of $14.80,14.50$ and 5.72 at.\%. Thus, the main Se source were derived from hydrothermal fluids, of anomalous Se-enrichment strata of Ediacaran-early Cambrian (ca. 635-520 Ma) of South Qinling Mountain.

Key words: Lujiaping Formation, Selenium, Hydrothermal activity, South Qinling Mountain. 


\section{Introduction}

Selenium (Se) exists in low concentrations in the Earth's crust $(\sim 0.05 \mathrm{ppm})$ (Liu et al., 1984), and it is not easily enriched to the extent that it can be of commercial importance. Se is an essential trace element for animals and humans (Rosenfeld 1964; Terry et al., 2000) but, in excess, can become toxic. For human consumption, this toxicity threshold is $400 \mathrm{mg} /$ day (Mac Farquhar et al., 2010), with possible consequences including neurotoxicity, cancer and diabetes (Vinceti et al., 2014; Sun et al., 2014). Trace elements enter soils primarily as a result of the weathering of trace element-bearing rocks (Foth, 1978). Anthropogenic metal input and natural geochemical sources of elements may influence trace element concentrations in soils and edible plants (Thornton, 1993).

In the 1960s, Se-poisoning was discovered in Shuang'an Town of Ziyang County, located in Shaanxi province (Central China), and the area with the greatest concern for selenosis in Shuang' an Town is very small, limited to Naore Village (Mei 1985). Luo et al (2004) suggested that the selenosis problem in Naore Village is due to the 40-meter-thick package of carbonaceous slate, black shale and volcanic tuff of the Ediacaran-early Cambrian (ca. 635-520 Ma) Lujiaping Formation (LFm), which crops out in the floor of the valley and weathers to Se rich soils, and $\mathrm{Se}$ concentrations vary from $0.324-42.3 \mathrm{ppm}$ (average Se content $=20.48 \mathrm{ppm}$ ). However, the origin of this high-Se strata is unclear. Se concentrations in the LFm strata range widely from 0.324 to several hundred ppm (Luo et al., 1994, 1995a, 2001, 2004; Fang et al., 2002; Wen et al., 2003), with the highest Se contents found in the siliceous rocks, with a concentration of 278 ppm (Feng et al., 2004). The thickness of the LFm is approximately 900 meters (Xiang et al., 1999); however, there has been no systematic study of the Se contents in the LFm strata, and samples of the LFm from previous studies are scattered. The distribution and enrichment patterns of Se and other trace elements in whole stratigraphic sequences of the LFm are unclear.

Additionally, the Ediacaran-Cambrian transition represents an important event in Earth's history (Knoll et al., 2006) and is a significant turning point in the radiation of complex multicellular life on Earth (Fike, 2006). The concentrations of bio-essential trace elements in the ocean, including Se, have had a major influence on evolutionary processes throughout time (Knoll et al., 2006; Morel, 2008). From 700 to $540 \mathrm{Ma}$, many of the trace elements (e.g., $\mathrm{Se}, \mathrm{Cr}, \mathrm{Ag}, \mathrm{Mo}, \mathrm{Cu}, \mathrm{Ni}$, and $\mathrm{Mn}$ ) rose by 1 to 2 orders of magnitude in response to the Great Oxygenation Event 2 (Large et al., 2014), accompanied by the diversification of phytoplankton and the appearance of eukaryotic clades (Shields-Zhou and Och, 2011), which were the preludes to the Cambrian Explosion (Large et al., 2014). Therefore, a study of the trace element distribution and enrichment patterns, and Se in particular, of Ediacaran-lower Cambrian strata in Ziyang selenosis will not only help us explore the Se resource and understand Se origin of the strata in geological history (especially during the key time of Ediacaran-early Cambrian) but also provide the basic data for further research on the relationship between trace elements and the evolution of multicellular life in earth's history.

In this paper, 468 fresh rock samples of LFm (Huoshibian sections in Ziyang County, Shaanxi Province) were collected from Sep. $28^{\text {th }}$ to Oct. $20^{\text {th }}, 2013$. We are currently investigating the distribution and enrichment patterns of trace elements (in particular Se) of the LFm of Ediacaran-early Cambrian and exploring the Se-origin of anomalous Se enrichment strata. 


\section{Geological setting}

The Qingling-Dabie-Sulun orogen, which stretches East-West for more than $2000 \mathrm{~km}$ between the North China Block and the South China Block (SCB), constitutes the geographic, geologic and cultural heart of China (Bader et al., 2013) (Fig.1.A and B). The Qingling Mountain (QM) is divided into two orogen, including North Qingling Mountain (NQM) and South Qingling Mountain (SQM) (Dong et al., 2011).

The South Qingling Mountain (SQM) is located in an inportant tectonic position linking the NQM and the SCB, and is characterized by thin-skinned structures which include south-vergent imbricated thrust-fold system (Dong et al., 2008), and redivided into (Southern of South Qingling Mountains) S-SQM and N-SQM (Northern of South Qingling Mountains). S-SQM consists of a pre-Sinian basement overlain by a thick pile of Neoproterozoic (Sinian) to early Paleozoci strata (Fig. 1C) (Lin et al., 2013).

The study area is located in the S-SQM (Fig. 1C). The main strata exposed in the S-SQM from older to younger are:

- The Yunxi Group (Ca.830-750 Ma (Cai et al., 2006; Ling et al., 2010) and Ca. $2500 \mathrm{~m}$ thick), composed of dacitic-rhyolitic lavas, pyroclastic tuffs, and basalt-andesites (Ling et al., 2010).

- The Yaolinghe Group (Ca.750-635 Ma (Cai et al., 2007) and Ca. 775 to 1500 $\mathrm{m}$ thick), mainly composed of (meta-) basic to acid volcanic rocks, tuffaceous rocks and fine-grained (meta-) sedimentary rocks, which is unconformably overlain by the Lujiaping Fomation (Xia and Xia, 2008; Zhu et al., 2014).

- The Lujiaping Fomation (LFm)(Ca.635-520 Ma and Ca. $900 \mathrm{~m}$ thick) is mainly composed of dark-black siliceous, shale, dolomite and interbedded with minor, barolite ore and volcanic tuff, which is conformably covered by the Jianzhuba Formation (Luo, 2006).

The other Lower Paleozoci strata is mainly composed of clastic and carbonate rocks (Zhang and Yu, 2000).

\section{Sampling and analytical methods}

\subsection{Sample description}

The LFm is divided into the following five members (Fig. 2 and 3) in ascending order: $I=1^{\text {st }}$ Member , $I=2^{\text {nd }}$ Member, $I I=3^{\text {rd }}$ Member, $I V=4^{\text {th }}$ Member, and $V=5^{\text {th }}$ Member. The $1^{\text {st }}$ Member, $2^{\text {nd }}$ Member and $3^{\text {rd }}$ Member are characterized by carbonate rocks interbedded with clastic rocks, including 6 series of carbonate and clastic rocks (series 1 to 6 ). The $4^{\text {th }}$ Member is characterized by black or light-green siliceous rock interbedded with witherite ore (ca. 2-meter-thick). The $5^{\text {th }}$ Member is characterized by gray or gray-black shale. Furthermore, based on the lithological features of the LFm from the lower to upper sections, it is also divided into 14 beds, which contain 6 beds of carbonate rocks (Bed 1, 3, 5, 7, 9 and 11) and 8 beds of clastic rocks (Bed 2, 4, 6, 8, 10, 12, 13, 14).

A detailed description of the LFm of the Southern Shaanxi Province is found in Table 1, including data regarding its thickness, sample location and lithology.

The bedding structure was observed on the dolomitic limestone. The structures of siliceous rocks and black shale are mainly bedded and laminated, respectively. Sharp-clasts were observed within the black shale.

Within the siliceous rocks, the crystal size of quartz tends to be quite variable, from several $\mu \mathrm{m}$ to several hundred $\mu \mathrm{m}$. Individual quartz crystals have irregular crenulate crystal boundaries and a pronounced undulose extinction (Fig. 4A and B), 
which is similar to typical micro-crystalline and meso-crystalline quartz, which results from the disordered crystallographic structure of individual grains (Knauth, 1994). The meso-crystalline quartz $(20-50 \mu \mathrm{m})$ is the most common recrystallized quartz phase in the siliceous rock samples. Large pores and cavities within these siliceous rock samples are commonly filled with length-fast mega-crystalline quartz, and there are also a few quartz veins (Fig. 4C).

The orbicular and nodular structures were observed within the black shale of HSBY 382 (Fig. 4E). Sporadic pyrite and deposition of organic matter were observed within the black shale of HSBY 601 under orthogonal polarized light (Fig. 4D). Within the HSBY 370 sample, a typical black shale of drill hole with pyrite aggregates in a dark matrix of quartz, adularia and chlorite, and chlorite (Chl) appears as light-gray patches compared to the dark-gray quartz-adularia matrix (Fig. 4E).

\subsection{Sample collecting}

The Huoshibian section is located in Maoba Town, which is the southernmost town of Ziyang County, Southern Shaanxi Province (in the southernmost edge of South Qinling Moutains), China, and exhibits an unusually complete and expanded stratigraphic column spanning the interval from the Neoproterozoic (Sinian) to the Lower Paleozoci sediments. Stratigraphic ordering of the whole horizons appears identical to the East-West's auxiliary roadside (Fig. 2 and Fig 4A). The Global Positioning System (GPS) locations and elevations (height above sea level) of the cross section from the start to the end point are $32^{\circ} 18.179^{\prime} \mathrm{N}-108^{\circ} 13.929^{\prime} \mathrm{E} 586 \mathrm{~m}$ and $32^{\circ} 18.188^{\prime} \mathrm{N}-108^{\circ} 13.415^{\prime} \mathrm{E} 613 \mathrm{~m}$, respectively.

A total of 497 fresh rock samples in $593.7 \mathrm{~m}$ thick strata were collected from the Huoshibian sections, including 29 samples of the Yaolinghe Group (underlain strata of the LFm) and 468 samples of the Lujiaping Formation. To ensure the investigated samples could reflect the overall characteristic of the Ediacaran and early Cambrian strata, the rock samples were collected densely over intervals of approximately $0.1 \mathrm{~m}$ to $3 \mathrm{~m}$ in this stratum. The positions of these samples in the stratigraphic column are shown in Figure 1C and 2B.

\subsection{Analytical methods}

Prior to chemical analyses, all the Lujiaping Formation rocks were firstly cleaned by deionized water to eliminate weathered surfaces, and secondly air-dried at room temperature, then fresh parts were chipped and ground into powder (less than 200 mesh) for analyses All samples were analyzed at Laboratory of Analytical and Testing Center (LATC) of the Institute of Geographic Sciences and Natural Resources Research (IGSNRR), Chinese Academy of Sciences (CAS), Beijing, China.

\section{Major and trace elements analysis}

Major and trace element compositions were analyzed by Elan DRC-e Inductively Coupled Plasma Optical Emission Spectrometer, standard X-rayfluorescence spectrometry methods and Perkin-Elmer Optima 5300DV Inductively Coupled Plasma Mass Spectrometry. Analyses of the Chinese national rock standards GBW07112 indicated that precisions and accuracies were both better than 5\%. Parallel samples, blank experiment, and repeated measurements were also used. Se and As were determined by Hydride Generation Atomic Fluorescence Spectrometer (Beijing Haiguang Instruments Co. Ltd). The procedures detailed for sample dissolution and calibration with international rock standards have been documented by Ni (2015) and Wang (2015) to which the reader is referred. 
The ratios of $\mathrm{Eu} / \mathrm{Eu}^{*}$ and $\mathrm{Ce} / \mathrm{Ce}^{*}$ were calculated by using published formulae (Bau and Dulski, 1999; Eu/Eu* $=2 \mathrm{Eu}_{N} /\left(\mathrm{Sm}_{\mathrm{N}}+\mathrm{Gd}_{\mathrm{N}}\right), \mathrm{Ce} / \mathrm{Ce}^{*}=2 \mathrm{Ce}_{\mathrm{N}} /\left(\mathrm{La}_{\mathrm{N}}+\mathrm{Pr}_{\mathrm{N}}\right), " N^{\prime}$ " refers to normalized concentrations against the shale standard PAAS (Taylor and McLennan, 1985).

\section{Loss on ignition (LOI) analysis}

A clean porcelain-crucible was placed in a muffle furnace and was heated to $900^{\circ} \mathrm{C}$ for 30 minutes. The porcelain crucible was removed from the furnace when the temperature fell to $500^{\circ} \mathrm{C}$, and was quickly placed in a desiccator. After 10-20 minutes, the weight of the porcelain crucible $\left(\mathrm{m}_{1}\right)$ was measured. $1.0 \mathrm{~g}$ of powdered sample $\left(\mathrm{m}_{2}\right)$ was put in the known-weight of porcelain-crucible and then heated again as described above. The weight of the heated sample was measured $\left(\mathrm{m}_{3}\right)$. The calculated LOI values are as follows: LOI $(\%)=\left[\left(\mathrm{m}_{1}+\mathrm{m}_{2}\right)-\mathrm{m}_{3}\right] / \mathrm{m}_{2} \times 100$.

\section{Pearson correlation method}

The method of Pearson correlation analysis was used in this paper. The "*”" represent that correlation is significant at the 0.05 level (2-tailed), while the "***" represent that Correlation is significant at the 0.01 level (2-tailed).

\section{Results}

\subsection{Major elements}

The major elements of the LFm of Ziyang County of southern Shaanxi Province, China, are given in Appendix as Supplementary Data. The average and range contents are listed into Table 2, of Carbonates and Clastics' major elements from the LFm of southern Shaanxi Province.

\subsection{Trace elements}

The trace elements of the LFm of Ziyang County of southern Shaanxi Province, China, are given in Appendix as Supplementary Data. The variation of the $\mathrm{Se}, \mathrm{Cd}$, Mo, $S$ and As contents of the most enrichment five trace elements of $14^{\text {th }}$ Bed of the LFm of southern Shaanxi Province are shown in Table 3. Enrichment patterns of trace elements of $14^{\text {th }}$ Bed of the LFm are shown in Figure 6. The trace element with a Concentration Coefficient $(\mathrm{CC}=$ ratio of element concentration in the $\mathrm{LFm}$ vs. upper continental crust (Taylor and Mclennan, 1985) is divided to five interval: $\mathrm{CC}>1000, \quad 1000>\mathrm{CC}>100, \quad 100>\mathrm{CC}>10,10>\mathrm{CC}>1, \mathrm{CC}<1$, which represent anomalous enrichment, supper enrichment, remarkable enrichment, slight enrichment and depletion of the corresponding elements, respectively.

The only trace element with a concentration coefficient $(\mathrm{CC})>100$ is $\mathrm{Se}$ $(\mathrm{CC}=324)$. Trace elements with a CC of 10 to 100 included $\mathrm{Cd}(\mathrm{CC}=53)$, Mo (31), S (22) and As (13). Other elements are slightly enriched in the LFm, including V (8.07), $\mathrm{Ba}$ (7.65), Ga (7.24), Zn (7.22), U (5.43), Cu (4.02), Bi (2.55), Tl (2.16), Ni (1.75), P (1.03). However, $\mathrm{Pb}(0.97), \mathrm{Cr}(0.97), \mathrm{Sr}(0.81)$, Li (0.78), In (0.69), Sc (0.69), Be (0.38), Cs (0.35), Co (0.30), Rb (0.29) and Th (0.26) are depleted (Fig. 9 A and B).

The Se contents of analysed samples are presented in Table 3; Selenium concentrations vary from 0.03 (HSBY607, dolomitic limestone) to $303 \mathrm{ppm}$ (HSBY601, black shale), with average value of $16.40 \mathrm{ppm}$ and concentration coefficient of 324.

Results shows that Se is the most highly enriched trace elements among the 27 
analyzed trace elements of the LFm in the Ediacaran-early Cambrian period. Among the $14^{\text {th }}$ Bed of the LFm, the average Se content of Bed $6\left(1^{\text {st }}\right.$ member $)$ is the highest, reaching to $49.20 \mathrm{ppm}(1.45-154 \mathrm{ppm})$ and it more than 947 times of the UCC (0.05 ppm, Taylor and Mclennan, 1985) and 84 times of the world shale average value (0.6 ppm, Turekian et al., 1961), respectively.

Among the $14^{\text {th }}$ Bed of the LFm, the average Se value of the ordering sequence is as follows: $\mathrm{B} 6(49.20 \mathrm{ppm})>\mathrm{B} 4(33.57 \mathrm{ppm})>\mathrm{B} 12(21.72 \mathrm{ppm})>\mathrm{B} 13(19.82$ ppm $)>$ B $10(17.88 \mathrm{ppm})>\mathrm{B} 5(10.07 \mathrm{ppm})>\mathrm{B} 8(9.90 \mathrm{ppm})>\mathrm{B} 11(9.25 \mathrm{ppm})>\mathrm{B}$ $2(6.90 \mathrm{ppm})>\mathrm{B} 9(6.24 \mathrm{ppm})>\mathrm{B} 3(5.34 \mathrm{ppm})>\mathrm{B} 7(2.75 \mathrm{ppm})>\mathrm{B} 14(2.29 \mathrm{ppm})$ > B 1 (0.30 ppm), respectively (Fig. 7A and B).

Additionally, Se, Cd, S, Mo, As, Ba, V, Ga and Bi are enriched in the Yaolinghe Group (Ca.750-653 Ma) and the LFm (Ca.635-520 Ma), however Co, Cs, Rb, Be and Th are depleted (Fig. 9A). Se, Cd, S, Mo, As, Ba, V, Ga and Bi contents of the LFm (Ca.635-520 Ma) are more than 206.77, 46.03, 1.45, 19.53, 11.40, 3.95, 5.71, 2.12 and 1.81 times of those elements of the Yaolinghe Group (Ca.750-653 Ma) (Fig. 9A). $\mathrm{Tl}$ is enriched in the $\mathrm{LFm}(\mathrm{CC}=2.16)$, and depleted in the Yaolinghe Group $(\mathrm{CC}=0.65) . \mathrm{Ni}, \mathrm{Cu}$ and $\mathrm{U}$ are enriched in the LFm (Ca.635-520 Ma), but depleted in the Yaolinghe Group (Ca.750-653 Ma) (Fig. 10A).

\section{Discussion}

\subsection{Anomalous Selenium significance}

\subsubsection{Anomalous Selenium availability}

Se belongs to a rare and dispersed group of elements, and it is not easily enriched to the extent that it can be of commercial importance. The Clarke value (Taylor, 1964) of Se in the crust and its concentration in all geological bodies are notably low and the occurrence of selenide minerals is scarce. It is difficult to extract selenium independently from other resources of industrial interest because of its low Clark value. Selenium comes primarily from selenium-containing deposits (Simon et al., 1997; Förster and Tischendorf, 2001; Butterman and Brown, 2004). Some Se-containing deposits have been described (Table 4), such as the La'erma-Qiongmo Au-Se deposit in West Qinling Orogenic (Wen and Qiu, 1999; Liu et al., 2000) and the Yutangba Se deposit in Enshi, Hubei Province (Song, 1989; Yao et al., 2002; Zhu, 2000; Feng et al., 2004). China is rich in selenium resources, which can be distinguished as different associated deposits as follows: magmatic, porphyry, skarn, hydrothermal and sedimentary. Se demand has been increasing year after year in international trade, and because global selenium resources are limited and not broadly distributed, the inconsistency between supply and demand of selenium is notable. Therefore, it is urgent for selenium resources to be reinforced through exploration, exploitation and utilization.

The Yutangba Se deposit in Southwest Hubei province is located in the northeast segment of the upper Yangtze platform. This location contains a rare highly concentrated Se deposit and is well known for high levels of Se which reach up to 8590 ppm (Feng et al., 2004). Deposits are approximately $6 \mathrm{~m}$ thick, and Se content ranges from 47 to $350 \mathrm{ppm}$, with an average of $84 \mathrm{ppm}$ (Table 4). However, Se content varies from 1120 to $5400 \mathrm{ppm}$ within the Se containing rocks specifically (Peng 1997). Se content is approximately $15.4 \mathrm{ppm}$ of some very large Au-Se deposits (Dexing, Jiangxi Province of China) (Table 4). The average Se content is 
approximately $50 \mathrm{ppm}$, of the Se-V Ore deposits of Zhoumafeng, in Hefeng County of Hubei province (Liu et al., 2001). Based on the specifications for rare metal mineral exploration (DZ/T0203-2002) and industrial grade metallic ore deposits (DZ/T02142002) from the Ministry of Land and Resources of the People's Republic of China, both deposit industrial indexes DZ/T0203-2002 and DZ/T02142002 show that the minimum $\mathrm{Cu}$ and $\mathrm{Se}$ contents are $0.5 \mathrm{wt} \%$ and $0.001 \mathrm{wt} \%$, respectively, and the minimum exploration thickness of a $\mathrm{Cu}-\mathrm{Se}$ deposit is $4 \mathrm{~m}$, for open-pit mining. Results shows that among the $14^{\text {th }}$ Bed of the LFm, the average Se value of the ordering sequence is as follows: $\mathrm{B} 6(49.20 \mathrm{ppm})>\mathrm{B} 4(33.57 \mathrm{ppm})>\mathrm{B} 12(21.72 \mathrm{ppm})$ > B $13(19.82 \mathrm{ppm})>$ B $10(17.88 \mathrm{ppm})>$ B $5(10.07 \mathrm{ppm})>$ B $8(9.90 \mathrm{ppm})>$ B 11 $(9.25 \mathrm{ppm})>$ B $2(6.90 \mathrm{ppm})>\mathrm{B} 9(6.24 \mathrm{ppm})>\mathrm{B} 3(5.34 \mathrm{ppm})>\mathrm{B} 7(2.75 \mathrm{ppm})>\mathrm{B}$ 14 (2.29 ppm) > B 1 (0.30 ppm), respectively (Fig. 7 A and B). Additionally, the LFm are widely distributed in southern Shaanxi Province. Therefore, based on the specifications of DZ/T0203-2002, DZ/T02142002 and the grade of the Se deposit presently being explored, Bed $6(\mathrm{Se}=49.20 \mathrm{ppm}$, range from 1.45 to $154 \mathrm{ppm}$, ca. 63.7- meter-thick, (Table 3 and 4) may be utilized as a Se source.

\subsubsection{Anomalous Selenium in the carbonate and clastic rocks of the LFm}

Enrichment patterns of trace elements in carbonate and clastic rocks of the LFm are shown into Figure 10B.

$\mathrm{S}, \mathrm{Mo}, \mathrm{Se}, \mathrm{Cu}, \mathrm{Ga}, \mathrm{V}, \mathrm{As}, \mathrm{Ba}, \mathrm{Bi}, \mathrm{Cd}$ and $\mathrm{Zn}$ are enriched in clastic and carbonate rocks of the LFm. Concentrations of $\mathrm{S}, \mathrm{Mo}, \mathrm{Se}, \mathrm{Cu}, \mathrm{Ga}, \mathrm{V}, \mathrm{As}, \mathrm{Ba}, \mathrm{Bi}, \mathrm{Cd}$ and $\mathrm{Zn}$ in the clastic rocks of LFm are more than 5.82, 4.88, 3.02, 2.97, 2.71, 2.35, $2.19,2.06,1.91,1.27$ and 1.21 times of those elements in the carbonate rocks.

$\mathrm{Co}, \mathrm{Cs}, \mathrm{Rb}, \mathrm{Be}, \mathrm{Th}$ and $\mathrm{Li}$ are depleted in clastic and carbonate rocks of the LFm. Contents of $\mathrm{Co}, \mathrm{Cs}, \mathrm{Rb}, \mathrm{Be}, \mathrm{Th}, \mathrm{Sc}$ and $\mathrm{Li}$ in clastic rocks of the $\mathrm{LFm}$ are lower than 2.27, 3.75, 3.37, 3.02 and 2.47 times of those elements in the carbonate rocks.

$\mathrm{Tl}, \mathrm{Ni}, \mathrm{Pb}$ and $\mathrm{Li}$ are enriched in the clastic rocks and depleted in the carbonate rocks. $\mathrm{Sr}$ is enriched in the carbonate rocks, and depleted in the clastic rocks of the LFm.

\section{Carbonate rocks}

The highest average Se, Mo and Cd concentrations in the LFm carbonate rocks are located in Bed 5 ( $1^{\text {st }}$ Member $)$, with average values of $10 \mathrm{ppm}(0.14-32 \mathrm{ppm}), 19$ ppm (0.00 -84 ppm) and $3.96 \mathrm{ppm}(0.00-72 \mathrm{ppm})$, respectively. Both the highest $\mathrm{S}$ and As average contents of LFm carbonate rocks are located in Bed 11 ( $3^{\text {rd }}$ Member), with values of $15435 \mathrm{ppm}$ (618- $49790 \mathrm{ppm})$ and $38 \mathrm{ppm}$ (11-156 ppm) (Table 3 and Fig. 10B).

\section{Clastic rocks}

Both the highest $\mathrm{Se}$ and Mo average contents of clastic rocks of the LFm are located in Bed 6 ( $1^{\text {st }}$ Member), with averages of 49 ppm (1.45-154 ppm) and 137 ppm (0.97-562 ppm), and their corresponding average concentration coefficients (CC) are 947 (3.05-3090) and 91 (0.65-376). Both the highest average $S$ and As contents are located in Bed $10\left(2^{\text {nd }}\right.$ Member $)$ and their average contents are 60512 ppm (3194$94300 \mathrm{ppm})$ and 48 (4.50-161 ppm), respectively, with corresponding average concentration coefficients of 172(9.13-269) and 32 (2.99-107). The highest Cd average content of clastic rocks are located on the Bed $4\left(1^{\text {st }}\right.$ Member $)$ with an average content of $13 \mathrm{ppm}$ (0.41-144 ppm), and a corresponding average concentration coefficient of 131 (4.21-1473) (Table 3 and Fig. 10B).

$\mathrm{Se}$ is an important trace element in the environment. The excess and deficiency 
of Se in the environment are closely related to human and animal health (Johnson et al. 2010; Rayman 2012). High levels of Se in the black shale suit of Ziyang County (Shaanxi Province, China) have implications for human and animal health due to soil composition and presence in edible plants (Fang et al., 2002). The Se contents of black shale parent rocks are important determinants of the concentration of Se in soils which satisfy the trace element needs of plants, humans, and livestock. Se concentrations in edible plants are influenced by Se concentrations in soils and waters (Fang et al., 2002; Yu et al., 2014). Thornton (1993) also suggested that trace element concentrations in soils and edible plants are controlled by anthropogenic metal input and natural geochemical sources. Negative environmental impacts can be caused by trace elements, such as $\mathrm{Se}, \mathrm{As}, \mathrm{Cu}, \mathrm{Cd}, \mathrm{Cr}, \mathrm{Co}, \mathrm{Pb}, \mathrm{Zn}$ and $\mathrm{Mo}$, from black shale (Yu et al., 2008). Black shale confers high levels of Se to ground waters through subsurface leaching (U.S. Department of Energy, (2011)), leaching of rock waste (Stillings and Amacher, 2010) and via overlying soils (Park et al., 2010; Tuttle et al., 2014). Bowland Shale (Central British Isles) is a black shale anomalously rich in trace elements, especially $\mathrm{Se}$ and As, which has the potential to release those elements into subsurface fluids (Parnell et al., 2016).

High $\mathrm{Se}, \mathrm{Cd}, \mathrm{Mo}, \mathrm{As}, \mathrm{Cu}$ and $\mathrm{Zn}$ concentrations in the carbonate and clastic rocks of the LFm of Ziyang County will result in high Se in soils through the process of weathering and leaching around the LFm rocks, which affect inhabitant and animal health through Se presence in soils and edible plants. This conclusion is also supported by Fang et al (2002). Therefore, we suggest that the potential threat for inhabitant and animal health persists.

\subsection{Se-origin of the LFm anomalous Se-enrichment rocks 5.2.1 Source of the $\mathrm{LFm}$ anomalous Se-enrichment rocks.}

\subsubsection{Constraints from elements geochemistry}

The concentrations of major, trace and rare earth elements of 40 anomalous Se-enrichment samples of the LFm are listed in Tables 5, 6 and 7, respectively. These samples include ten of siliceous rock, twenty-seven of black shale and three of dolomitic limestone, which are located in $1^{\text {st }}$ Member (s2 and 3), $2^{\text {nd }}$ Member (s4 and s5), $3^{\text {rd }}$ Member (s6) and $4^{\text {th }}$ Member (s7).

\section{Major elements}

Siliceous rocks of hydrothermal origin have relatively lower $\mathrm{Mg}$ and $\mathrm{Al}$ and higher Fe and Mn contents compared to siliceous rocks of non-hydrothermal origin (Yamamoto 1987). For example, $\mathrm{MgO}$ has been found to be depleted in mid-ocean ridge hydrothermal systems; in hydrothermal fluids $\left(350^{\circ} \mathrm{C}\right)$ taken from the East Pacific Rise mid-ocean ridge, the $\mathrm{MgO}$ content is near zero (Edmond and Damm 1983). The $\mathrm{MgO}$ contents in ten siliceous rock samples are mostly less than 0.4 (Table 5), which is consistent with a hydrothermal origin (Yamamoto 1987).

In the $\mathrm{Y}_{2} \mathrm{P}_{2} \mathrm{O}_{5}$ plot (Fig. 11C), the 40 anomalous Se-enrichment samples in this study are located in modern hydrothermal sediments or within the area outlined for hydrothermal-type metalliferous sediments (HD) but are distant from the fields of diagenic-type metalliferous sediments.

In addition, detrital and authigenic components contribute to the trace element concentrations in bulk black shales (Tribovillard et al., 2006). An effective method to assess whether the content of a given element is dominantly controlled by the detrital flux is to plot this trace element versus aluminum ( $\mathrm{Al}$ ) or titanium (Ti), which can be considered as an indicator of the aluminosilicate fraction of the sediments, which is not mobile during diagenesis (Tribovillard et al., 2006; Schröder and Grotzinger, 
2007). In table 8, Pearson correlation analysis shows the following: (1) no significant positive correlations between Se with $\mathrm{Al}$ of the $1^{\text {st }} \operatorname{Member}\left(R_{\mathrm{Se}-\mathrm{Al}}=0.13, \mathrm{n}=22\right), 2^{\text {nd }}$ Member $\left(R_{\text {Se-Al }}=0.51, \mathrm{n}=4\right), 3^{\text {rd }} \operatorname{Member}\left(R_{\text {Se-Al }}=0.45, \mathrm{n}=9\right)$ and $4^{\text {th }} \operatorname{Member}\left(R_{\text {Se-Al }}=\right.$ $-0.75, \mathrm{n}=4)$; (2) no significant positive correlations between Se with Ti in both $2^{\text {nd }}$ Member $\left(R_{\mathrm{Se}-\mathrm{Ti}}=0.35, \mathrm{n}=4\right)$ and $4^{\text {th }} \operatorname{Member}\left(R_{\mathrm{Se}-\mathrm{Ti}}=-0.75, \mathrm{n}=5\right)$ while significant positive correlations between Se with Ti in both $1^{\text {st }}$ Member $\left(R_{\mathrm{Se}-\mathrm{Ti}}=0.44^{*}, \mathrm{n}=22\right)$ and $3^{\text {rd }}$ Member $\left(R_{\mathrm{Se}-\mathrm{Ti}}=0.85^{* *}, \mathrm{n}=9\right)$. Therefore, both the $R_{\mathrm{Se}-\mathrm{Al}}$ and $R_{\mathrm{Se}-\mathrm{Ti}}$ of Pearson correlation analysis suggest that anomalous Se-enrichment samples of $1^{\text {st }}$ and $3^{\text {rd }}$ Member of the LFm are influenced by detrital provenance, but $2^{\text {nd }}$ and $4^{\text {th }}$ Member are not controlled by terrigenous input.

\section{Trace elements}

High As, Mo, Ba, Cu, Ni, V and $\mathrm{Zn}$ concentrations in sediments should be influenced by hydrothermal activity (Yamamoto, 1987), because these elements could have been leached by hydrothermal fluids flowing through the dolomites and contributed to the above-mentioned acidic, high Cl-rich and high-temperature hydrothermal fluids (Barrett et al., 1988). As, Mo, $\mathrm{Ba}, \mathrm{Cu}, \mathrm{Ni}, \mathrm{V}$ and $\mathrm{Zn}$ are anomalously enriched in the 40 anomalous Se-enrichment samples of the LFm (Table 6). The $\mathrm{CC}$ of $\mathrm{As}, \mathrm{Mo}, \mathrm{Ba}, \mathrm{Cu}, \mathrm{Ni}, \mathrm{V}$ and $\mathrm{Zn}$ of ten siliceous rocks are 24.19, 42.66, 6.26, 5.15, 3.52, 17.92 and 12.67, respectively. The $\mathrm{CC}$ of $\mathrm{As}, \mathrm{Mo}, \mathrm{Ba}, \mathrm{Cu}, \mathrm{Ni}, \mathrm{V}$ and $\mathrm{Zn}$ of twenty-seven black shale are 36.85, 126.56, 9.64, 7.12, 5.49, 29.68 and 9.62, respectively. The $\mathrm{CC}$ of $\mathrm{As}, \mathrm{Mo}, \mathrm{Ba}, \mathrm{Cu}, \mathrm{Ni}, \mathrm{V}$ and $\mathrm{Zn}$ of three dolomitic limestone are 27.73, 6.16, 5.30, 3.54, 2.36, 9.94 and 11.73, respectively (Table 6).

Additionally, the Co to $\mathrm{Zn}$ ratio of 40 anomalous Se-enrichment samples ranges from 0.009 to 0.0913 , with an average value of 0.017 (Table 6), which is less than that of BIF iron ore deposit $(\mathrm{Co} / \mathrm{Zn}=0.15$, hydrothermal origin) and iron-manganese ore deposit $(\mathrm{Co} / \mathrm{Zn}=2.5$, normal deposition) (Toth, 1980). In Figure 11A, the 40 samples are plotted into I area, which also indicates that these samples are influenced by hydrothermal fluids during their formation (Boström et al., 1973). In the $(\mathrm{Cu}+\mathrm{Co}+\mathrm{Ni}) \times 10-\mathrm{Fe}-\mathrm{Mn}$ diagram (Fig. 11C), all but four samples fall within the field for hydrothermal sedimentation from the Red Sea, which indicates that these 36 anomalous Se-enrichment samples are display characteristics that suggest they are of hydrothermal origin.

The U/Th ratio varies from 1.19 to 1011 (avg=43) (Table 6), of 39 anomalous Se-enrichment samples, which is slightly high than that of hydrothermal sediments (U/Th > 1) (Girty et al., 1996; Rona, 1988), but the U/Th of black shale (HSBY318, Bed 4 of $1^{\text {st }}$ Member) is 0.76 . In Figure $11 \mathrm{~B}$, the 39 samples are plotted onto the FH (Fossil Hydrothermal Sedimentary) and ED (Eastern Pacific Ocean Hydrothermal Deposition) areas, which indicate hydrothermal-originated features. One sample (HSBY318, Bed 4 of $1^{\text {st }}$ Member) is plotted into the deep sea area.

Therefore, 40 anomalous Se-enrichment samples of this study are further characterized by low $\mathrm{Co} / \mathrm{Zn}$ ratios (averaging 0.017 , high $\mathrm{U} / \mathrm{Th}$ ratios (1.19- 1011), and high $\mathrm{As}, \mathrm{Mo}, \mathrm{Ba}, \mathrm{Cu}, \mathrm{Ni}, \mathrm{V}$ and $\mathrm{Zn}$ contents (Table 6), which is typical of hydrothermal origin (Bostrom et al. 1979; Marchiget al. 1982), excluding four samples from the $1^{\text {st }}$ and $3^{\text {rd }}$ Member of the LFm.

\section{Rare earth element (REE)}

It is necessary to estimate the influence of terrigenous materials before interpreting the REE signatures of the studied 40 anomalous Se-enrichment samples. No systematic relationships of total REE ( $\mathrm{REE}$, excluding yttrium), Y/Ho, $\mathrm{Ce} / \mathrm{Ce}^{*}$ 
and $\mathrm{Eu} / \mathrm{Eu}^{*}$ with $\mathrm{TiO}_{2}$ were observed (Table $11, R_{\text {¿REE-TiO2 }}=-0.039, R_{\mathrm{Y} / \mathrm{Ho}-\mathrm{TiO} 2}=-0.282$, $\left.R_{\mathrm{Ce} / \mathrm{Ce} e^{*} \mathrm{TiO} 2}=0.122, R_{\mathrm{Eu} / \mathrm{Eu}^{*}-\mathrm{TiO} 2}=0.22 ; \mathrm{n}=40\right)$, which suggested that the $\mathrm{REE}$ characteristics of these samples are not significantly contaminated by terrigenous materials (Sugahara et al., 2010).

REE composition is an important indicator used to distinguish hydrothermal sediments from those of a non-hydrothermal origin (Marchig et al., 1982; Wang et al., 1989). Generally, hydrothermal sedimentary are characterized by $\sum$ REE and typical hydrothermal siliceous rock's $\sum$ REE is below 200 ppm (Murray et al., 1991). In table 7 and figure 12, $\sum$ REE contents vary from 8.11 to $312 \mathrm{ppm}$ in 40 anomalous Se-enrichment samples of the LFm. $1^{\text {st }}$ Member ranges from 51 to $312 \mathrm{ppm}$ (avg= $194 \mathrm{ppm}), 2^{\text {nd }}$ Member ranges from 8.11 to $177 \mathrm{ppm}(\mathrm{avg}=90), 3^{\text {rd }}$ Member ranges from 36 to $169 \mathrm{ppm}(\mathrm{avg}=87 \mathrm{ppm})$ and $4^{\text {th }}$ Member ranges from 16 to $101 \mathrm{ppm}$ (avg= $50 \mathrm{ppm}) . \quad \sum \mathrm{REE}$ of 9 anomalous Se-enrichment black shales of $1^{\text {st }}$ Member are 300 ppm (HSBY318), 312 ppm (HSBY370), 245 ppm (HSBY372), 285 ppm (HSBY375), 202 ppm (HSBY384), 213 ppm (HSBY386), 271 ppm (HSBY387), 263 ppm (HSBY388), 255 ppm (HSBY401), which indicate that they are influenced by terrigenous materials. $\sum$ REE of 31 samples of anomalous Se-enrichment of the LFm are below $200 \mathrm{ppm}$, which indicate that they are characterized by hydrothermal sediments.

In the sea floor hydrothermal system, REE patterns of vent fluids generally show an apparent enrichment in LREE (Light Rare Earth Element) relative to HREE (High Rare Earth Element) with pronounced positive Eu anomalies and weak or no negative Ce anomalies (Michard et al., 1983; German et al., 1991). This is a result of crysto-chemical exchange with plagioclase phenocrysts formed in the vent and speciation of vent fluids (Douville et al., 1999). Therefore, sediments deposited from vent fluids generally inherit the REE patterns of the parent vent fluids, i.e., with positive Eu anomalies (German et al., 1991), although REE patterns will vary as the influx of ambient sea water increases. From figure 11, REE patterns normalized by PAAS show a flat or moderate leftward inclination with slightly Ce negative anomaly and a significant positive Eu anomaly, of 40 samples of anomalous Se-enrichment of the LFm, which is consistent with those of sediments of hydrothermal genesis (Fig. 12 A, B, C, D and F). The REE patterns of 40 anomalous Se-enrichment samples of the LFm are similar to the patterns of the Yaolinghe group (underlain strata of the LFm) (Fig. 12E), which may support the proposal that the Se and other elements tend to be associated with basic to acid volcanic rocks (especially $\mathrm{Ni}$ and $\mathrm{V}$ ). All of the LREE/HREE vary from 1.7 to 20.6 (Table 7) and are to over 1, of 40 anomalous Se-enrichment samples of the LFm, which indicate their hydrothermal origin.

$\mathrm{Eu}$ is the only rare earth element that can be reduced from $\mathrm{Eu}^{3+}$ to $\mathrm{Eu}^{2+}$ (Brookins, 1989). Positive Eu anomalies in shallow seawater may not reflect the redox state of waters but are always associated with high temperature $\left(>250^{\circ} \mathrm{C}\right)$ (Sverjensky, 1984) and reducing hydrothermal fluid (Michard and Albarède, 1986; Kamber and Webb, 2001). In table 7, Eu/Eu* of 38 anomalous Se-enrichment samples range from 1.07 to 4.83 . Eu/Eu* show an increasing trend upward, with $1^{\text {st }}$ Member range from 1.09 to $2.09(\mathrm{avg}=1.40), 2^{\text {nd }}$ Member range from 1.20 to 1.38 $(\mathrm{avg}=1.29), 3^{\text {rd }}$ Member range from 1.12 to $4.00(\operatorname{avg}=2.38)$ and $4^{\text {th }}$ Member range from 2.51 to $4.48\left(\mathrm{avg}=3.56\right.$ ). However, $\mathrm{Eu} / \mathrm{Eu}^{*}$ of 2 samples are 0.90 (HSBY324, Bed 4 of $1^{\text {st }}$ Member) and 0.95 (HSBY401, Bed 6 of $1^{\text {st }}$ Member). These Eu/Eu* 
features indicate that 38 anomalous Se-enrichment samples are characterized by hydrothermal fluid, except HSBY324 and HSBY401 of $1^{\text {st }}$ Member of the LFm.

Furthermore, Douville (2005) suggested that high temperature water-rock interaction could not fractionate $\mathrm{Y}$ and Ho resulting in the chondritic values of hydrothermal fluids (Y/Ho as 26-27). Additionally, modern deep-sea hydrothermal fluids' Y/Ho varying from 25 to 50, and Y/Ho of the "black smokers" and "white smokers" hydrothermal fluids are 25-28 and 30-35, respectively (Bau and Dulski, 1999). In table 7 and figure 12, Y/Ho of 37 anomalous Se-enrichment samples range from 27.73 to 44.55 , but HSBY403 (Bed 6 of $1^{\text {st }}$ Member), HSBY573 (Bed 12 of $3^{\text {rd }}$ Member) and HSBY574 (Bed 12 of $3^{\text {rd }}$ Member) samples are 18.86, 23.22 and 21.42, respectively.

\subsubsection{Constraints from the petrographic evidence.}

Siliceous rock is characterized by typical micro-crystalline, meso-crystalline texture and bed structure. In Bed 3 ( $1^{\text {st }}$ Member $)$, Bed 8 ( $2^{\text {nd }}$ Member $)$, and Bed 13 $\left(4^{\text {th }}\right.$ Member) (Fig. 5A), these features are similar to the structure of typical hydrothermal siliceous rock. These features, including metasomatic residual texture and recrystallization phenomena are not observed in all parts of the LFm, which indicate that these samples were influenced by contemporaneous hydrothermal activity rather than later activity (Knauth, 1994). Orbicular, nodular structure (Fig. 4E) and sharp-clast (Fig. 5C1) were observed within black shale of HSBY 382 sample (Bed 6 of $1^{\text {st }}$ Member), which are similar to the feature of typical hydrothermal black shale (Yang et al., 2005). Graded-bedding structures are observed within dolomitic limestone (Bed 11 of $3^{\text {rd }}$ Member) with fine grain, which are influenced by hydrothermal activity (Yang et al., 2005). Sporadic pyrite was also seen within black shale of HSBY601 (Fig. 4D), and fine-grains and undeformed pyrite were observed within the siliceous rock of HSBY307 (Fig. 4F) The pyrite texture suggests a contemporaneous hydrothermal origin (Knauth, 1994), and this conclusion was also supported by a few calcite veins of dolomitic limestone (Fig. 5D) and pseudo-parallel mega-crystalline quartz vein (Fig. 4C).

Anomalous concentrations of $\mathrm{Se}$, together with $\mathrm{S}, \mathrm{Mo}, \mathrm{Se}, \mathrm{Cu}, \mathrm{As}, \mathrm{Cd}$ and $\mathrm{Zn}$ in the Ediacaran-lower Cambrian strata, is not only distributed in the Ziyang County but also in many parts of the Yangtze and Tarim cratons of southern and western China. This anomalous elemental association and their concentration within a limited stratigraphic interval occurring over a wide area suggests that the enrichment processes may have been controlled by contemporaneous hydrothermal activity (rather than the latter).

Therefore, based on section 5.2.1.1 and 5.2.1.2, the 40 anomalous Se-enrichment samples of the LFm are consistent with sediments of hydrothermal genesis. However, some samples from the $1^{\text {st }}$ and $3^{\text {rd }}$ Member of the LFm are also influenced by terrigenous input.

\subsubsection{Connection between the Se with hydrothermal activity}

Forty anomalous Se-enrichment samples of the LFm are strongly influenced by contemporaneous hydrothermal activity. However, this study aims to understand whether there is a connection between Se content and hydrothermal activity.

$\mathrm{Se}$ is a typical dispersed element with a low crustal concentration $(0.05 \mathrm{ppm})$ (Liu, 1984) and tends to enrich toward the core of the Earth (Xia et al., 1995). Se concentrations in modern seawater are approximately $0.08 \mathrm{ppb}$, but because of the low oxidation rate of $\mathrm{Se}, \mathrm{S} / \mathrm{Se}$ ratios are high (e.g., seawater shows ratios $>\times 10^{8}$ )(Measures and Burton, 1980). Se contents in sulfides of most clastic 
sedimentary rocks and evaporites are also low, and the $\mathrm{S} / \mathrm{Se}$ ratios are more than 100,000 (Measures and Burton, 1980). Although Se may be enriched in organic-rich black shale formed in anoxic basins, Se concentrations range usually from several ppm to tens ppm (Stanton, 1972; Howard, 1977). However, in this study, Se contents of 40 anomalous Se-enrichment samples ranges from $47 \mathrm{ppm}$ to $303 \mathrm{ppm}$, which cannot be entirely explained by anoxic basins. This is also supported by the Se contents (more than several hundreds and thousands ppm) of Zunyi Ni-Mo-Se deposit of Guizhou Province in China (Wen and Garignan 2011).

Some researchers suggested that Se tends to increase in high-temperature systems (Nough and Sun, 1995; Hamlyn et al., 1986). Se in hydrothermal sulfide minerals are highly variable but are universally higher. For example, at $13^{\circ} \mathrm{N}$, high Se values up to $2500 \mathrm{ppm}$ occur in high-temperature mineral assemblages in the middle of the deposit (Auclair et al., 2014). High Se contents are also found in pyrite (200 ppm) in volcanic-hosted Cu-rich massive sulfide deposits (Huston et al., 1995). The S/Se ratios are relatively lower in MOR hydrothermal fluxes $(\sim 4000)$ (And and Schultz, 1996), in the primitive mantle ( 3300) (Nough and Sun, 1995) and in MOR basalts (3000-6000) (Hamlyn et al., 1986). As shown in Figure 13 and Table 6, in the $1^{\text {st }}$ Member of the LFm, S/Se ranges from 17 to 875 , with increasing-upward trend. In the $2^{\text {nd }}$ Member, S/Se of siliceous rocks (Bed 8) are 11 (HSBY 446) and 20 (HSBY 456), with a slight decreasing upward trend in this Member. Then, S/Se increase to 834 (black shale of HSBY513 of Bed 10 of $2^{\text {nd }}$ Member). In the $3^{\text {rd }}$ and $4^{\text {th }}$ Member, $\mathrm{S} / \mathrm{Se}$ range from 21 to 893, with a decreasing-upward trend (Fig. 12). The S/Se of 40 anomalous Se-enrichment samples range from 11 to 893 (Table 6), which are below 3-5 orders of magnitude of clastic sedimentary rocks and evaporites of modern water origin $\left(\mathrm{S} / \mathrm{Se}>\times 10^{5}\right)$, but closer to that of high-temperature hydrothermal fluids $(\mathrm{S} / \mathrm{Se}=\sim 1000)$ (Wignall, 1994). Among the 40 samples, HSBY 446 and HSBY 456 ( $2^{\text {nd }}$ Member) siliceous S/Se are lowest, which indicates that the degrees of hydrothermal activity within $2^{\text {nd }}$ Member are more extensive than the $1^{\text {st }}, 3^{\text {rd }}$ and $4^{\text {th }}$ Member. The boiling point of Se is $682.9^{\circ} \mathrm{C}$, and its isomorphism could be expanded under high temperatures; therefore, Se is more easily enriched in high temperature sediment than in low temperature sediment (Lott et al., 1999; Liu, 1984). Therefore, the measurements mentioned above indicated that hydrothermal fluids (rather than seawater) provide a large amount of Se for 40 anomalous Se-enrichment samples of the LFm from the Ediacaran-early Cambrian time.

Enriched $\mathrm{Ba}$ in sediment is an indication of a hydrothermal contribution to sediments (Weaver and Tarney, 1984), because minerals of hydrothermal sediments consist of barite $\left(\mathrm{BaSO}_{4}\right)$, cymrite $\left(\mathrm{BaAlSi}_{3} \mathrm{O}_{8}(\mathrm{OH})\right)$ and coronite $\left(\mathrm{NaMg}_{3} \mathrm{Al}_{6}\left(\mathrm{BO}_{3}\right)_{3} \mathrm{Si}_{6} \mathrm{O}_{18}(\mathrm{OH})_{3}(\mathrm{OH})\right)(\mathrm{Qi}, 1999)$. Barite mineral deposits account for $13 \%$ of hydrothermal sediments of oceanic spreading centers. Ba content is higher than $1 \%$ in $47 \%$ of hydrothermal sediments of oceanic spreading centers. The Ba content is approximately $6.3 \%$ in hydrothermal sediments of the East African rift (Rona, 1988). Weaver and Tarney (1984) report that Ba contents are 1079.3, 1079.3, 1375 and 1869 ppm in hydrothermal sediments, siliceous rock, metal-rich shale and black shale, respectively. Our data show that the average Ba content is 3828, 4505 and 2914 ppm (Table 6), for ten siliceous rock, twenty-seven black shale and three dolomitic limestone. There is a significant positive correlation between $\mathrm{Se}$ and $\mathrm{Ba}$ $\left(R_{\mathrm{Se}-\mathrm{Ba}}=0.738^{* *}, \mathrm{n}=40\right.$, Table 10$)$. Additionally, approximately $2.5 \mathrm{~m}$ thick witherite deposits were distributed on Bed 13 of $4^{\text {th }}$ Member (Table 1). Ba contents of HSBY677B, 677C and 677E samples are 112100, 144200 and 138700 ppm, with corresponding Se concentrations of $24 \mathrm{ppm}, 10 \mathrm{ppm}$ and $24 \mathrm{ppm}$, respectively 
(Appendix). Figure 14 illustrates that the nor.C of Ba (L Series) are 55.50 wt.\%, $54.94 \mathrm{wt} . \%$ and $27.20 \mathrm{wt} . \%$, respectively, in a three-point X-ray energy spectrometric analysis of black shale mineral anomalous Se-enrichment samples (HSBY601), with a corresponding Atom. $\mathrm{C}$ of 14.80, 14.50 and 5.72. Finally, more than forty witherite deposits or witherite-barite deposits (Ediacaran-early Cambrian) have been discovered in Ziyang county, which hosts some of the largest Ba deposits in China and is also among the world's largest witherite deposits (Lv et al., 2004).

\subsubsection{Sedimentary environment}

The Ziyang Se-enrichment areas as studied in this article are located the Caledonian fold belt of the North Daba Mountains(Mei 1985; Luoet al. 2001, 2004). Hydrothermal siliceous rocks appear to be preferentiallyformed in extensional, rift type environments or fault-controlled basins, and tend to be associated with large-scale syn-sedimentary faults. For example, the La'erma-Qiongmo Se deposit in western Qinling is located on the Bailongjiang Great Fault (Lill et al. 2000).

The Ediacaran early Cambrian "black rock series" lithologies comprise earbonate, black shale, stone-coal, siliceous shate, chert, carbonaceous siliceous rock, and carbonaceous slate (Fan 1983; Orberger et al. 2007; Feng et al.2010), and is not only distributed in Ziyang area of the Southern Shatnxi province of S SQM but alse in many parts of the Yangtze cratons. On the one hand, the absence of coarse-grained sediments within the sequence of Huoshibian section (this study) would appear to exclude a shallow marine environment. On the other hand, sporadic pyrite and deposition of organic matter were observed within black shale (Figure 4C), Fine-grains and undeformed pyrite were also observed with the siliceous rock (Figure 4F). Almost no fossils of benthon and bioturbation were observed from filed and section's photomicrographs. Those indicate that the LFm are considered to have formed in a deep to semi-deep sea sedimentary environment.

Molybdenum ( $\mathrm{Mo}$ ) is conservative under the oxic marine environment, with the exides form of $\mathrm{MoO}_{4}{ }^{2-}$, but in the anoxic marine environment, $S$ will replace $O$ and form the thiomolybdate: $\mathrm{MoO}_{4}{ }^{2-} \rightarrow \mathrm{MoO}_{x} \mathrm{~S}_{4-\mathrm{x}}(\mathrm{x}=0-3)$, and then form the $\mathrm{MoS}_{4}{ }^{2}$ under more sulfide environment, finally $\mathrm{Mo}$ is enriched into sediments (Algeo and Lyons, 2004). In this study, $\mathrm{Mo}$ are anomaly enriched in the 40 anomalous Se-enrichment samples of the LFm (Table-6). The average Mo contents of ten siliceous rocks, twenty-seven black shales and three dolomitic limestone are more than $42.66,126.56$ and 6.16 times of the upper continental crust (Table 6). Pearson correlation analysis showed that there is a significant positive correlations between $\mathrm{Mo}$ with $\mathrm{V}$ $\left(R_{\mathrm{Mo}-\mathrm{Al}}=0.516 * *, \mathrm{n}=40\right.$, Table 10$)$, which indicate that they formed under the anoxic marine environment (Yang et al., 2004).

Additionally, negative Ce anomalies have been found mostly within the ocean basins since seawater is typically depleted in Ce due to the preferential removal of $\mathrm{Ce}^{+}$from the water column (Elderfield and Greaves, 1982) and likely sinking in manganese nodules in view of their positive Ce anomalies (Fleet, 1983). The $\mathrm{Ce} / \mathrm{Ce} *$ values were proven fairly consistent during diagenesis (Murray et al., 1992), thus are valuable to identify the depositional environment (Murray et al., 1990, 1991; Ding and Zhong, 1995). Previous studies (Murray et al., 1990, 1991) show that sediments deposited near ocean spreading ridges have the lowest Ce/Ce* values (avg. 0.29), while those deposited on the ocean basin floor have the intermediate $\mathrm{Ce} / \mathrm{Ce}^{*}$ values (avg=0.60), and those deposited on continental margins basin have the higher $\mathrm{Ce} / \mathrm{Ce} *$ values $(0.791 .78, \mathrm{avg}=1.03)$. In table 7 and figure 12, HSBY370 sample (Bed 6 of $4^{\text {st }}$ Member) have a obvious negative $\mathrm{Ce}$ anomalies $\left(\mathrm{Ce} / \mathrm{Ce}^{*}=0.38\right)$, suggesting a deep 
sea environment. Ce/Ce* show an increasing trends upward (Fig. 12) and $2^{\text {nd }}$ Member range from 0.58 to $0.83,3^{\text {rd }}$ Member range from 0.63 to 1.93 and $4^{\text {th }}$ Member range from 0.69 to 0.83 (Table 7), suggesting a semi-deep sea environment, which indicate that the SQM sedimentary environment evolved from the ocean basin to continental margins basin during the Ediacaran-Early Cambrian time. This scenario is further demonstrated by the $(\mathrm{La} / \mathrm{Ce})_{\mathbb{N}}$ values that mainly cluster between 1.0 and 1.5, which are also in a good agreement with the values of continentat margins basin (0.5-1.5) proposed by Murray (1994). HSBY370 sample (Bed 6 of $1^{\text {st }}$ Member) also show the highest (La/Ce) ${ }_{\mathbb{N}}$ values (2.35) (Table 7 and Fig. 12), which are in a good agreement with the values of open ocean basins (1.5-2.5) propesed by Murray(1994).

Therefore, during the Ediacaran-early Cambrian time, the South Qingling Mountains were located in a rift basin (Tang et al., 2007). Based on this regional tectonics characteristic and these data mentioned above, we conclude that frequent magmatic activities carried a large amount of hydrothermal fluids the basin; thus, the circulation of hydrothermal fluids could have easily carried a large amount of Se. High temperatures enabled enriched Se in the LFm and then ultimately formed anomalous Se-enrichment sediments.

\section{Conclusion}

1) The only trace element with a concentration coefficient (CC) $>100$ was $\mathrm{Se}$ $(\mathrm{CC}=324)$. Trace elements with a CC of 10 to 100 included $\mathrm{Cd}(\mathrm{CC}=53)$, Mo (31), S (22) and As (13). Other elements were slightly enriched in the LFm, including V (8.07), Ba (7.65), Ga (7.24), Zn (7.22), U (5.43), Cu (4.02), Bi (2.55), Tl (2.16), Ni (1.75), P (1.03). However, $\mathrm{Pb}(0.97), \mathrm{Cr}(0.97), \mathrm{Sr}(0.81), \mathrm{Li}(0.78)$, In (0.69), Sc (0.69), Be (0.38), Cs (0.35), Co (0.30), Rb (0.29) and Th (0.26) were depleted

2) Se concentrations in the LFm range from 0.03 (sample no. of HSBY607, dolomitic limestone) to $303 \mathrm{ppm}$ (sample no. of HSBY601, black shale), with an average value of $16 \mathrm{ppm}$ and $\mathrm{CC}$ of 324. The average Se content of Bed $6\left(1^{\text {st }}\right.$ Member, ca. 63-meter-thick) was the highest, reaching $49.20 \mathrm{ppm}(1.45-154 \mathrm{ppm})$, among the $14^{\text {th }}$ Bed of the LFm, which may be utilized as a Se resource. Additionally, $\mathrm{S}, \mathrm{Mo}, \mathrm{Se}, \mathrm{Cu}, \mathrm{As}, \mathrm{Cd}$ and $\mathrm{Zn}$ were enriched in clastic and carbonate rocks of the LFm. A potential threat for inhabitant and animal health still exists.

3) Anomalous Se-enrichment beds from the $1^{\text {st }}, 2^{\text {nd }}, 3^{\text {rd }}$ and $4^{\text {th }}$ Members of the LFm were consistent with those of sediments of hydrothermal genesis, and the degrees of hydrothermal activity within $2^{\text {nd }}$ Member was more extensive than the $1^{\text {st }}$, $3^{\text {rd }}$ and $4^{\text {th }}$ Members. However, those samples from the $1^{\text {st }}$ and $3^{\text {rd }}$ Member of the LFm were also influenced by terrigenous input. Contemporaneous hydrothermal fluids provide a large amount of Se to those anomalous Se-enrichment bed of LFm of Ediacaran-early Cambrian in Southern of South Qingling Mountains.

\section{Acknowledgements}

The authors express their heartfelt thanks to Du Yanjun and Xiang Linhua for helping us collect the samples in the fieldwork. We gratefully acknowledge the editor and anonymous reviewers for their constructive comments and suggestions. This work was supported financially by the Chinese National Science Foundation Project (41172310,41472322), the Major State Basic Research Development Program (973) (2014CB238906), and the National High Technology Research and Development Program (863) of China (2004AA601080, 2006AA06Z380). 


\section{References}

And, H.E., Schultz, A., 1996. Mid-ocean ridge hydrothermal fluxes and the chemical composition of the ocean. Annual Review of Earth \& Planetary Sciences 24, 191-224.

Auclair, G., Fouquet, Y., Bohn, M., 2014. Distribution of selenium in high-temperature hydrothermal sulfide deposites at 13 degrees North, East Pacific Rise. Canadian Mineral 25, 577-587.

Bader, T., Ratschbacher, L., Franz, L., Yang, Z., Hofmann, M., Linnemann, U., Yuan, H.,2013. The heart of China revisited, I. Proterozoic tectonics of the Qin mountains in the core of supercontinent Rodinia. Tectonics 32,661-687

Barrett, T.J., Anderson, G.M., Lugowski, J., 1988. The solubility of hydrogen sulphide in 0-5 $\mathrm{m} \mathrm{NaCl}$ solutions at $25^{\circ}-95^{\circ} \mathrm{C}$ and one atmosphere. Geochimica Et Cosmochimica Acta 52, 807-811.

Bau M, Dulski P. 1999. Comparing yttrium and rare earths in hydrothermal fluids from the Mid-Atlantic Ridge: implications for $\mathrm{Y}$ and REE behaviour during near-vent mixing and for the Y/Ho ratio of Proterozoic seawater. Chemical Geology, 1999, 155, 77-90.

Boström, K., Kraemer, T., Gartner, S., 1973. Provenance and accumulation rates of opaline silica, Al, Ti, Fe, Mn, Cu, Ni and Co in Pacific pelagic sediments. Chemical Geology 11, 123-148.

Bostrom, K., Rydell, H., and Joensuu, O., 1979, Langbank: Anexhalative sedimentary deposit: Economic Geology, v. 74, p.1002-1011.

Brookins, D., 1989. Aqueous geochemistry of rare earth elements. Reviews in Mineralogy and Geochemistry, 21: 201-225.

Butterman, W.C., Brown, R.D., 2004. Mineral Commodity Profiles: Selenium. Open-File Report.

Cai, Z.Y., Luo H., Xiong, X.L., Wu, D.K., 2006. A discussion on the age of the meta-sedimentary rocks in the upper part of the wudang group: constrained by the grain-zircon U-Pb dating. Journal of Stratigraphy, 30, 60-63.

Cai, Z.Y., Xiong, X.L., Luo H., Wu, D.K., Sun, S.C, and Rao, B.L, 2007. Forming age of the volcanic rocks of the yaolinghe group from wudang block, southern qinling mountain: constraint from grain-zircon U-Pb dating. Acta Geologica Sinica, 81, 620-625.

Chen, N.S., 1990, Lower Cambrian black shale series and associ-ated stratiform deposits in southwest China: Chinese Journal of Geochemistry, 9, 244-255.

Dong, Y.P., Zhou, M.F., Zhang, G.W., Zhou, D.W., Liang, L., Qi, Z., 2008. The Grenvillian Songshugou ophiolite in the Qinling Mountains, Central China: implications for the tectonic evolution of the Qinling orogenic belt. J Asian Earth Sci. Journal of Asian Earth Sciences 32, 325-335.

Dong, Y.P., Zhang, G.W, Neubauer, F., Liu, X.M, Genser, J., and Hauzenberger, C. 2011. Tectonic evolution of the qinling orogen, china: review and synthesis. Journal of Asian Earth Sciences, 41, 213-237.

Douville E, Bienvenu P, Charlou J. L., 1999. Yttrium and rare earthelements in fluids from various deep-sea hydrothermal systems. Geochimica et Cosmochimica Acta, 63 , 627-643.

Elderfield, H., Greaves, M.J., 1982. The rare earth elements inseawater. Nature 296, 214 - 219.

Ellis, D.R., and Salt, D.E., 2003. Plants, selenium and human health. Curr. Opin. Plant Biol, 6, 273-279.

Foth, H.D., 1978, Fundamentals of Soil Science, 4th edn, Wiley, New York.

Fan, D.L., 1983, Polyelements in the Lower Cambrian blackshale series in southern China, in Augustithis, S.S., ed., The significance of trace metals in solving petrogenetic problems and controversies: Athens, The Ophrastus Publication,p. 447-474.

Fan, D.L., Yang, R.D., and Huang, Z.X., 1984, The LowerCambrian black shale series and iridium anomaly in SouthChina, in Development in Geoscience, Contributions to the27th International Geological Congress, Moscow: Beijing,Science Press, 215-224.

Fang, W.X., Hu, R.Z, and Wu, P.W., 2002. Influence of black shales on soils and edible plants in the ankang area, shaanxi province, P. R. of china. Environmental Geochemistry and 
Health, 24, 35-46.

Feng, C.X., Liu, J.J., Hu, R.Z., and Liu, S., 2004, Geochemistryof the Yutangba Se Deposit in Western Hubei, China: Chinese Journal of Geochemistry, 23, 255-264.

Feng, C.X., Liu, S., Hu, R.Z., Liu, J.J., Luo, T.Y., Chi, G.X., and Qi, Y.Q., 2010, Geochemistry of Lower Cambrian Se-rich black rock series in Guizhou Province, southwest of China:The petrogenesis and enrichment mechanism of selenium:Earth Science- Journal of China University of Geosciences, 35, 947-958 (in Chinese with English abstract).

Feng, C.X., Chi, G.X., and Liu, J.J., 2012, Geochemical constrains on the origin and environment of Lower Cambrian, selenium-rich siliceous sedimentary rocks in the Ziyang area, Daba region, central China. International Geology Review, 54, 765-778.

Fike, D.A.G., J. P; Pratt, L. M; Summons, R.E, 2006. Oxidation of the Ediacaran Ocean. Nature 444, 744-747.

Fleet, A.J., 1983. Hydrothermal and hydrogenous ferro-manganesedeposits: Do they form a continuum? The rare earth element evidence. In: Rona, P.A., Boström, K., Laubier, L., Smith, K.L.(Eds.), Hydrothermal Process at Seafloor Spreading Centers. Plenum Press, New York, 535 -555.

Förster, H. J., Tischendorf, G., 2001. Se-rich tennantite and constraints on p-T-X conditions of selenide mineral formation in the Schlema-Alberoda uranium ore district (western Erzgebirge, Germany). Neues Jahrbuch für Mineralogie - Abhandlungen 176, 109-126.

German C. R., Holliday B. P., 1991. Elderfield H. Redox cycling of rareearth elements in the suboxic zone of the Black Sea.Geochimica et Cosmochimica Acta, 55. 3535-3558.

Hamlyn, P.R., Keays, R.R., Hamlyn, P.R., 1986. Sulfur saturation and second-stage melts; application to the Bushveld platinum metal deposits. Economic Geology 81, 1431-1445.

Howard J. H. 1977. Geochemistry of selenium: formation offerroselite and selenium behavior in the vicinity of oxidizingsulfide and uranium deposits. Geochim. Cosmochim. Acta 41,

Huston, D.L., Cooke, D.R., Sie, S.H., Suter, G.F., Both, R.A., 1995. Trace elements in sulfide minerals from eastern Australian volcanic-hosted massive sulfide deposits; Part I, Proton microprobe analyses of pyrite, chalcopyrite, and sphalerite, and Part II, Selenium levels in pyrite; comparison with delta $34 \mathrm{~S}$ values and implications for the source of sulfur in volcanogenic hydrothermal systems. Economic Geology 90, 1167-1196.

Johnson C.C., Fordyce F.M., Rayman M.P., 2010. Symposium on "Geographical and geological influences on nutrition": factors controlling the distribution of selenium in the environment and their impact on health and nutrition. Proc Nutr Soc, 69: 119-132. doi:10.1017/S0029665109991807.

Knoll, A.H., Walter, M.R., Narbonne, G.M., N., C.-B., 2006. The Ediacaran Period: a new addition to the geologic time scale. Lethala 39, 13-30.

Knauth, L.P., 1994. Petrogensis of chert. Silica Physical Behavior Geochemistry \& Materials Applications 29, 233-258.

Large, R.R., Halpin, J.A., Danyushevsky, L.V., Maslennikov, V.V., Bull, S.W., Long, J.A., Gregory, D.D., Lounejeva, E., Lyons, T.W., Sack, P.J., McGoldrick, P.J., Calver, C.R., 2014. Trace element content of sedimentary pyrite as a new proxy for deeptime ocean-atmosphere evolution. Earth Planet. Sci. Lett. 389, 209-220.

Lin, Z.W., 2013. Zircon U-Pb dating and geochemistry of the volcanic rocks at Huachanggou area, Mian-Lue suture, South Qinling. Acta Petrologica Sinica 29, 83-94.

Ling, W.L., Duan, R.C., Liu, X.M., Cheng, J.P., Mao, X.W., Peng, L.H., Liu, Z.X., 2010. U-Pb dating of detrital zircons from the Wudangshan Group in the South Qinling and its geological significance. Chinese Science Bulletin 22, 2440-2448.

Liu, Y. J., 1984. Element geochemistry (in Chinese). Science Press, Beijing.

Liu, J. J., 1993. Geochemistry of hydrothermal sedimentary silicalite. Acta geologica Sichuan, 13. 110-118.

Liu, J.J., Zheng, M.H., Liu, J.M., and Su, W.C., 2000, Geochemistry of the La'erma and Qiongmo Au-Se depositsin western Qinling Mountains, China: Ore Geology Review, 17, 91-111.

Liu, J.J., Feng, C.X., and Zhang, M.H., 2001. The studying situation on selenium resource and 
its exploiting and utilizing prospect (in Chinese). World Sci-tech R \& D.

Lott, D.A., Coveney, R.M.J., Murowchick, J.B., Grauch, R.I., 1999. Sedimentary exhalative nickel-molybdenum ores in south China. Economic Geology 94, 1051-1066.

Luo, K.L., Chen, D.M., Ge, L.M., 1994. Accompanied and associated ores of the Paleozoic black shale and coal, Shaanxi Province, China. Northwest University Press, Xi'an pp 36-46.

Luo, K.L., Jiang, J.S., 1995a. Enrichment of Selenium in stone coal in South Qinling Mountain and its significance (in Chinese). Journal of Chang Chun U Earth Sci 25, 125-130.

Luo, K.L., Su, W.Z., Du, M.L., Lei, F.Y., 1995b. Some microelements of lower Paleozoic stone coal in South Qinling. Journal of Xi'an Mining Institute.

Luo, K. L., Pan, Y. T., Wang, W. Y. \& Tan, J. A. 2001 Selenium content and distribution pattern in the Palaeozoic strata in the southern Qinling Mountains. Geological Review, 47(2), 211-217.

Luo, K.L., Xu, L.R., Tan, J.A., 2004. Selenium source in the selenosis area of the Daba region, South Qinling Mountain, China. Environmental Geology 45, 426-432.

Luo, K.L., 2006. The Lujiaping formation of Northern Daba Mountain. Journal of Stratigraphy $30,149-156$.

Luo, K. L., 2011, Arsenic and Fluorine Contents and Distribution Patterns of Early Paleozoic Stone like Coal in the Daba Fold Zone and Yangtze Plate, China: Energy Fuels, v. 25, p. 4479-4487.

Lv, Z.C., Liu, C.Q., Liu, J.J., 2004. The bio-barite in witherite deposits from Southern Qinling and its significance. Progress in Natural Science Materials 10, 889-895.

Mac Farquhar, J.K., Broussard, D.L., Melstrom, P., Hutchinson, R., Wolkin, A.,Martin, C., Burk, R.F., Dunn, J.R., Green, A.L., Hammond, R., Schaffner, W.Jones, T.F., 2010. Acute selenium toxicity associated with a dietary supplement.Archives Intern. Med. 170, 256-261.

Marchig, V., Gundlach, H., and Moller, P., 1982, Some geochemical indication for determination between diagenetic and hydrothermal metalliferous sediments: Marine Geology, 50, 241-256.

Measures, C.I., Burton, J.D., 1980. The vertical distribution and oxidation states of dissolved selenium in the northeast Atlantic Ocean and their relationship to biological processes. Earth \& Planetary Science Letters 46, 385-396.

Mei, Z.Q., 1985. Summary on two selenium-rich areas of China (in Chinese). Journal of Chinese Endemic 12, 379-385.

Michard, A., and Albarède, F., 1986. The REE content of some hydrothermal fluids. Chemical Geology, 55: 51-60.

Morel, F.M.M., 2008. The co-evolution of phytoplankton and trace element cycles in the oceans. Geobiology 6, 318-324

Murray, R.W., Buchholtz ten Brink, M.R., Jones, D.L., Gerlach, D.C.,Russ III, G.P., 1990. Rare earth elements as indicators of differentmarine depositional environments in chert and shale. Geology 18,268 - 271.

Murray, R.W., Gerlach, D.C., Iii, G.P.R., Jones, D.L., 1991. Rare earth, major, and trace elements in chert from the Franciscan complex and Monterey group, California: Assessing REE sources to fine-grained marine sediments. Geochimica Et Cosmochimica Acta 55, 1875-1895.

Murray, R.W., Buchholtz ten Brink, M.R., Gerlach, D.C., RussIII, G.P., Jones, D.L., 1992. Rare earth, major, and traceelement composition of Monterey and DSDP chert and associated host sediment: assessing the influence of chemicalfractionation during diagenesis. Geochim. Cosmochim. Acta, 56, 2657- 2671.

Murray, R.W., 1994. Chemical criteria to identify the depositional environment of chert: general principles and applications. Sediment. Geol. 90, 213 - 232.

Ni, R. X., 2015. Distribution and enrichment mechanism of selenium and arsenic in Ediacaran-Early Cambrian strara of southern Hunan and southern Shananxi Province and its environmental effects (In Chinese) [Ph.D. disertation]: Beijing, China, the Institute of 
Geographic Sciences and Natural Resources Research, Chinese Academy of Sciences (in Chinese with English abstract)

Nough, W. F., Sun, S.S., 1995. The composition of the Earth. Chemical Geology 120, 223-253.

Park, M., Chon, H.T., Marton, L., 2010. Mobility and accumulation of selenium and its relationship with other heavy metals in the system rocks/soils-crops in areas covered by black shale in Korea. J. Geochem. Explor. 107, 161-168.

Parnell, J., Brolly, C., Spinks, S., and Bowden, S. 2016. Selenium enrichment in carboniferous shales, britain and ireland: problem or opportunity for shale gas extraction?. Applied Geochemistry, 66, 82-87.

Peng, D. M, 1997, Selenium resources of China: an outline. Geology of Chemical Minerals (in Chinese with English abstract). 19, 37-42.

Qi, S.J., 1999. The upper Paleozoic submarine exhalative sedimentary metallogenic system in South Qinling. Earthence Frontiers 6, 171-178.

Rona, P.A., 1988. Hydrothermal mineralization at oceanic ridges. Canadian Mineralogist 26, 431-465.

Rosenfeld, I., Beath, O.A., 1964. Selenium : geobotany, biochemistry, toxicity, and nutrition. Academic Press.

Schröder, S., and Grotzinger, J.P., 2007. Evidence for anoxia at the Ediacaran-Cambrian boundary: the record of redox-sensitive trace elements and rare earth elements in Oman. Journal of the Geological Society, 164: 175-187.

Shields-Zhou, G., Och, L., 2011. The case for a neoproterozoic oxygenation event: Geochemical evidence and biological consequences. GSA Today 21, 4-11.

Simon, G., Kesler, S.E., Essene, E.J., 1997. Phase relations among selenides, tellurides, and oxides; II, Applications to selenide-bearing ore deposits. Economic Geology 92, 468-484.

Slack J.F., Grenne T, Bekker A. 2007. Suboxic deep seawater in thelate Paleoproterozoic : Evidence from hematitic chert and ironformation related to seafloor-hydrothermal sulfide deposits, centralArizona, USA. Earth and Planetary Science Letters, 2007, 255, 243-256.

Song, C.Z., 1989, A brief description of the Yutangba sedimentary-type selenium mineralized area in southwesternHubei: Mineral Deposits, 8, 83-89. (in Chinese with English abstract).

Stanton R. L. 1972. Ore Petrology. Mc Graw-Hill Book Company, New York.

Stillings, L.L., Amacher, M.C., 2010. Kinetics of selenium release in mine waste from the Meade peak phosphatic shale, Phosphoria Formation,Wooley Valley, Idaho, USA. Chem. Geol. 269, 113e123.

Sverjensky, D.A., 1984. Europium redox equilibria in aqueous solution. Earth and Planetary Science Letters, 67: 70-78.

Sugahara, H., Sugitani, K., Mimura, K., Yamashita, F., Yamamoto, K., 2010. A systematic rare-earth elements and yttrium study of Archean cherts at the Mount Goldsworthy greenstone belt in the Pilbara Craton: Implications for the origin of microfossil-bearing black cherts. Precambrian Research 177, 73-87.

Sun, H.J., Rathinasabapathi, B., Wu, B., Luo, J., Pu, L.P., Ma, L.Q., 2014. Arsenic and selenium toxicity and their interactive effects in humans. Environ. Int. 69,148-158.

Tang, Y.Z., Qi, W., Liu, S.W., Hou, M.T., 2007. Paleozoic hydrothermal sedimentary basin and hydrothermal sedimentary mineralization in the Southern Qinling. Geology in China 34, 1091.

Taylor, S.R., 1964. Trace element abundances and the chondritic Earth model. Geochim.Cosmochim. Acta 28, 1989-1998.

Taylor, S.R., Mclennan, S.M., 1985. The continental crust: Its composition and evolution. Journal of Geology 94.

Terry, N.; Zayed, A.M.; de Souza, M.P.; Tarun, A.S., 2000. Selenium in higher plants. Annu. Rev. Plant Physiol. Plant Mol. Biol, 51, 401-432.

Thornton, I., 1993, Geochemistry applied to agriculture, in: I. Thornton (ed.) Applied Environmental Geochemistry, Academic Press, London, pp. 231-266.

Toth, J.R., 1980. Deposition of submarine crusts rich in manganese and iron. Geological 
Society of America Bulletin, 91: 44-54.

Tribovillard, N., Algeo, T.J., Lyons, T., and Riboulleau, A., 2006. Trace metals as paleoredox and paleoproductivity proxies: An update. Chemical Geology, 232: 12-32.

Turekian, K.K., Wedepohl, K.H., 1961. Distribution of the Elements in Some Major Units of the Earth's Crust. Geological Society of America Bulletin 72, 175.

Tuttle, M.L.W., Fahy, J.W., Elliott, J.G., Grauch, R.I., Stillings, L.L., 2014. Contaminants from Cretaceous black shale: I. Natural weathering processes controlling contaminant cycling in Mancos Shale, southwestern United States, with emphasis on salinity and selenium. Appl. Geo chem. 46, 57-71.

U.S. Department of Energy, 2011. Natural Contamination from the Mancos Shale. Experimental Sciences Laboratory Report ESL-rpt-2011-01

Vinceti, M., Mandrioli, J., Borella, P., Michalke, B., Tsatsakis, A., Finkelstein, Y., 2014.Selenium neurotoxicity in humans: Bridging laboratory and epidemiological studies. Toxicol. Lett. 230, 295-303.

Wang, J, 2015. The Geochemistry of the coals at P/Tboundary in Xuanwei, Yunnan and its Paleoenvironmental significance (In Chinese) [Ph.D. disertation]: Beijing, China, China University of Ming\&tTechnology, Beijing (in Chinese with English abstract)

Wang, Z.G., Yu, X.Y., and Zhao, Z.H., 1989, The geochemistry of REE: Beijing, Science Press (in Chinese).

Weaver, B.L., Tarney, J., 1984. Empirical approach to estimating the composition of the continental crust. Nature 310, 575-577.

Wen, H.J., and Qiu, Y.Z., 1999, Organic and inorganic occurrence of selenium in La'erma Se-Au deposit: Science in China(Series D), 29, 426-432.

Wen, H. J., Qiu, Y.Z., Yao, L.B., Lu, J.L., Peng, P.A., Lin, Q. 2000. Organic geochemistry and biomakers of some lower Cambrian high-selenium formations in China. Geochimica, 29, 28-35.

Wen, H. J., Qiu Y.Z., and Lin H.W., 2003. Geochemistry and gensis of beded cherts in some typical eopaleozoic high selenium black shales, China. Acta Sedimentological Sinica 21, 619-626.

Wen, H. J., Garignan J., 2011. Selenium isotopes trace the source and redox processesin the black shale-hosted Se-rich deposits in China. Geochimicaet Cosmochimica Acta 75, 1411-1427.

Wignall, P.B., 1994. Black Sahles [M]. Oxford, Claredon Press, 127.

Xia, B.D., Zhong, L.R., Fang, Z., Lu, H., 1995. The origin of cherts of the Early Precambrian Gufeng fomation in the lower Yangtze area, Eastern China. Acta Geologica Sinica 4, 325-331.

Xia, L.Q., Xia, Z.C., 2008. Petrogenesis of the Yaolinghe Group,Yunxi Group,Wudangshan Group Volcanic Rocks and Basic Dyke Swarms from Eastern Part of the South Qinling Mountains. Northwestern Geology 41, 1-29.

Xiang, L.W., Zhu, Z.L., 1999. China stratigraphy. Beijing: Geological Publishing House.

Xu, L.G., Lehmann, B., Mao, J.W., Nägler, T.F., Neubert, N., Böttcher, M.E., Escher, P., 2012. Mo isotope and trace element patterns of Lower Cambrian black shales in South China: Multi-proxy constraints on the paleoenvironment. Chemical Geology 318, 45-59.

Yamamoto, K., 1987. Geochemical characteristics and depositional environments of cherts and associated rocks in the Franciscan and Shimanto Terranes. Sedimentary Geology 52, $65-108$.

Yang, J. H., Jiang, S. Y., 2004. Peleoceangrphic significance of redoc-sensitive metals of black shale in the basal Lower Cambrian Niutitang Formation in Guizhou Province' South China. Progress in Natural Science, 14, 152-157.

Yang, R.D., Zhu, L.J., Gao, H., Zhang, W.H., Jiang, L.J., Wang, Q., 2005. A Study on Characteristics of the Hydrothermal Vent and Relating Biota at the Cambrian Bottom in Songlin, Zunyi County, Guizhou Province. Geological Review 12, 214-223.

Yao, L.B., Gao, Z.M., Yang, Z.S., and Long, H.B., 2002, Originof seleniferous cherts in Yutangba Se deposit, Southwest Enshi, Hubei Province: Science in China (Series D), 45, 
741-854.

Yu, B.S., and Qiu, Y.Z., 1998, The geochemistry of sedimentaryrocks and its relation to crustal evolution in the southwest Yangtze Massif: Chinese Journal of Geochemistry, 17, 265-274.

Yu, B.S., Dong, H.L., Widom, E., Chen, J.Q., and Lin, C.S., 2009, Geochemistry of basal Cambrian black shales and cherts from the Northern Tarim Basin, Northwest China: Implications fordepositional setting and tectonic history: Journal of Asian Earth Sciences, 34, 418-436.

Yu, C.X., Peng, B. Tang, X.Y., 2008. The black shale and relative heavy metal contamination of soils derived from the black shale. Bulletin of Mineralogy Petrology \& Geochemistry, 27, 137-145.

Yu T, Yang Z.F., Lv Y.Y., 2014. The origin and geochemical cycle of soil selenium in a Se-rich area of China. Journal of Geochemical Exploration, 139, 97-108.

Zhang, G.W., Yu, Z.P., 2000. On Precambrian framework and evolution of the Qinling belt. Acta Petrologica Sinica.

Zhao C.Y, Ren J.H, Xue C.Z (1993) Selenium in soils of selenium-rich areas in Ziyang County (in Chinese). Acta Pedolog Sin 30, 253-259

Zhou, Y.Z., 1990. On sesimentry geochemistry of siliceous rocks originated from thermal wateral in Nandan-Hechi basin. Acta Sedimentologica Sinica.

Zhou, Y.Z., Edward, H., Huangzhang, L.U., 1994. Hydrothermal Origin of Top Sinian Chert Formation at Gusui, Western Guangdong,China:Petrologic and Geochemical Evidence. Acta Sedimentologica Sinica.

Zhu, J.M., 2000. Modes of occurrence of Se in the black Se-richrocks of Yutangba and its impact on the local environment (in Chinese) [Ph.D. dissertation]: Guiyang, GuizhouProvince, China, Institute of geochemistry, Chinese Academyof Sciences (in Chinese with English abstract).

Zhu, X.Y., Chen, F.K., Nie, H., Siebel, W., Yang, Y.Z., Xue, Y.Y., Zhai, M.G., 2014. Neoproterozoic tectonic evolution of South Qinling, China: Evidence from zircon ages and geochemistry of the Yaolinghe volcanic rocks. Precambrian Research 245, 115-130. 


\section{Figure}

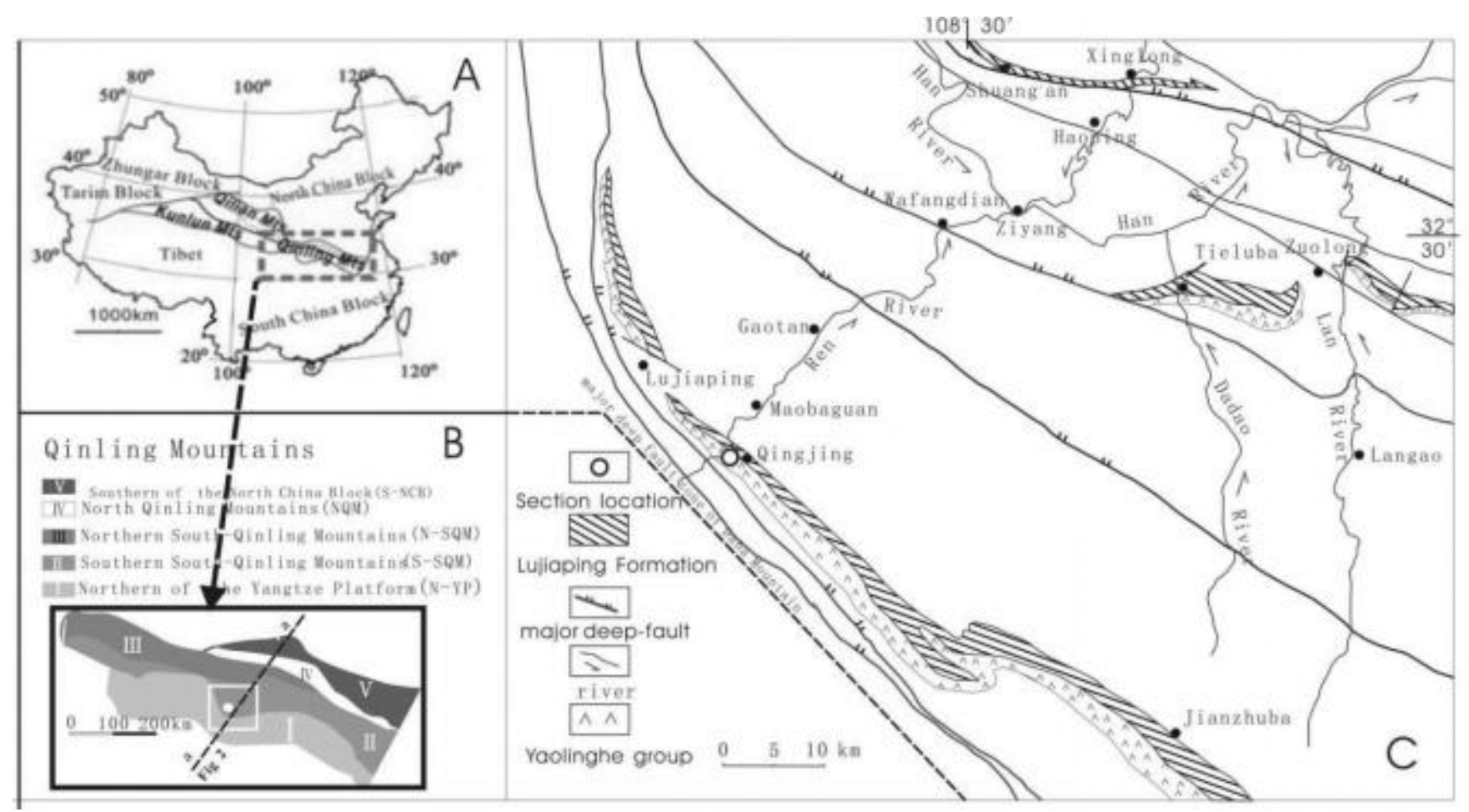

3 Figure 1. A The location of Qinling Mountains within China. (modified form Dong et al., 2009). B Simplified geologic map of South Qinling Mountains 4 (modified after Dong et. al., 2011). C The Sketch map of Lujiaping formation in South Qinling Mountains and location of sample collection, modified from 5 (Luo, 2006). 


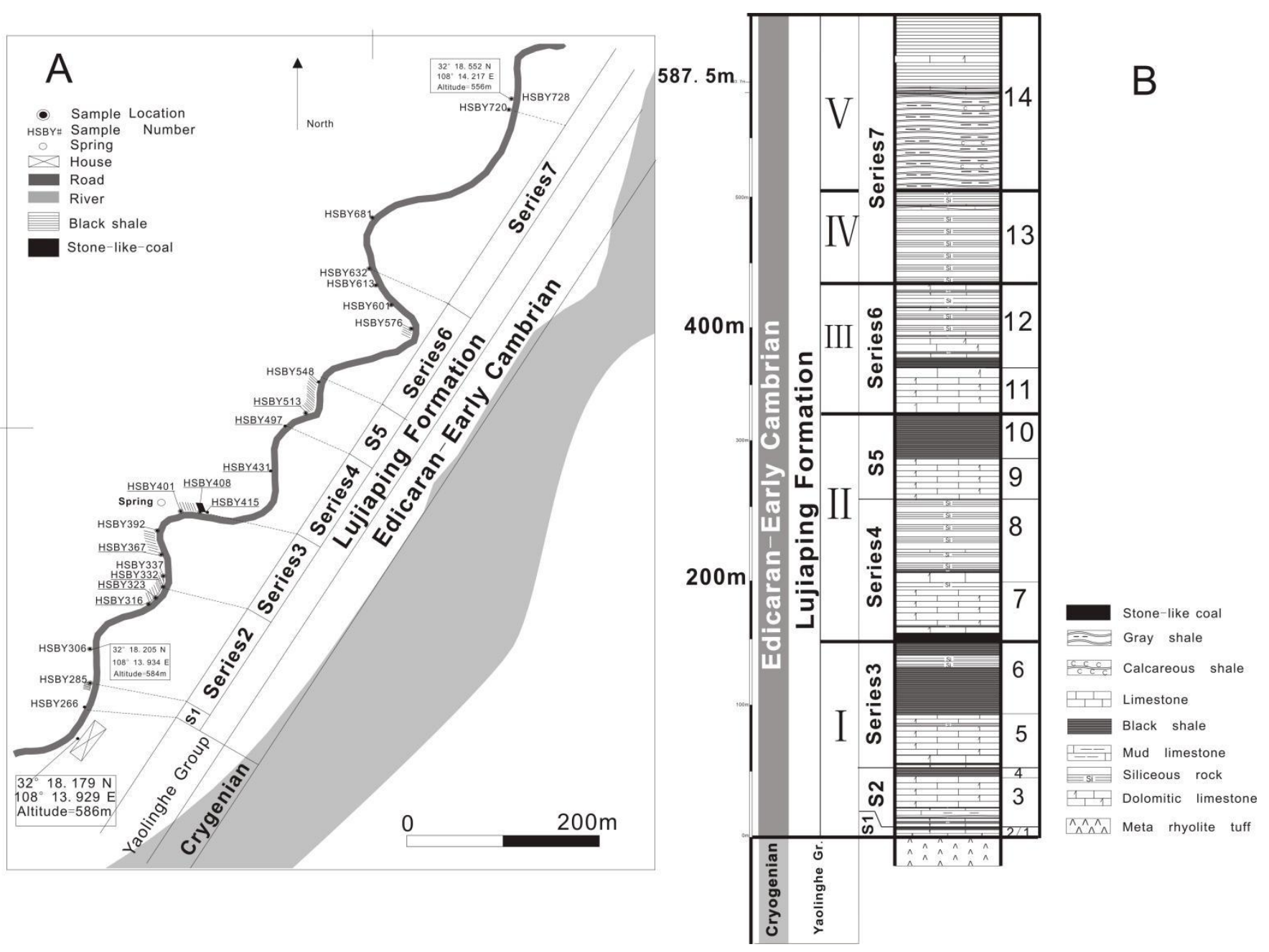

Figure 2. A Route map. B Columnar map of Huoshibian section. 


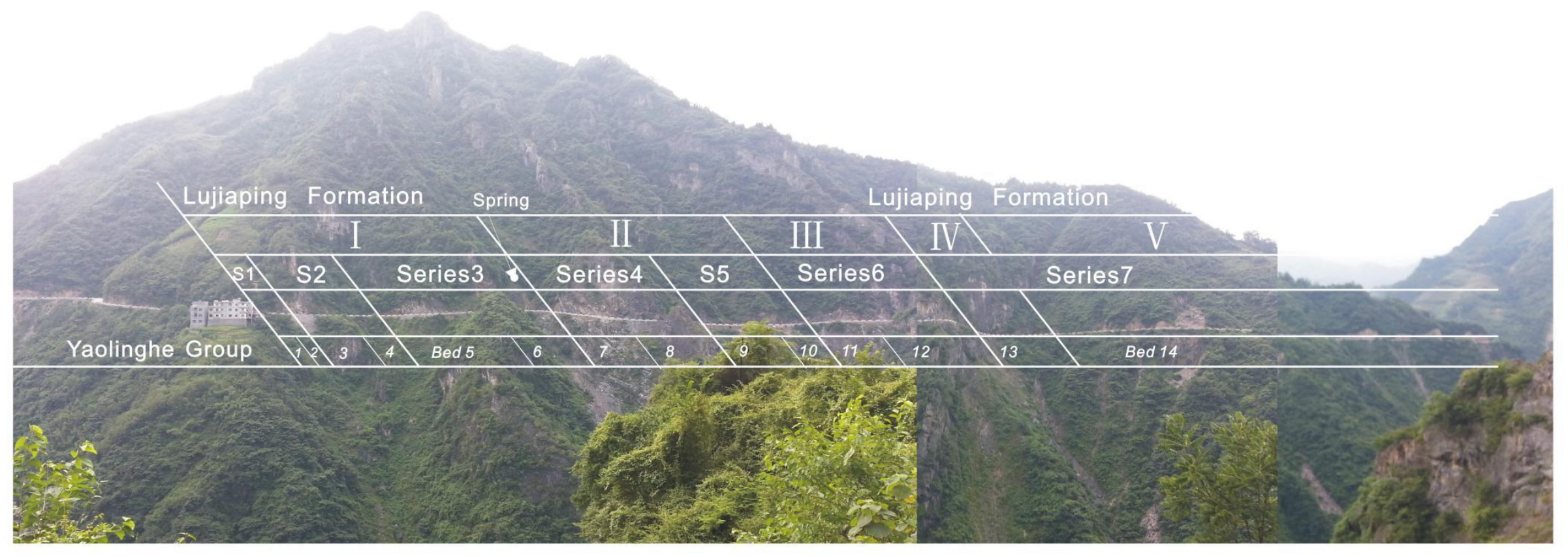

9 Figure 3 The overview of Huoshibian section 

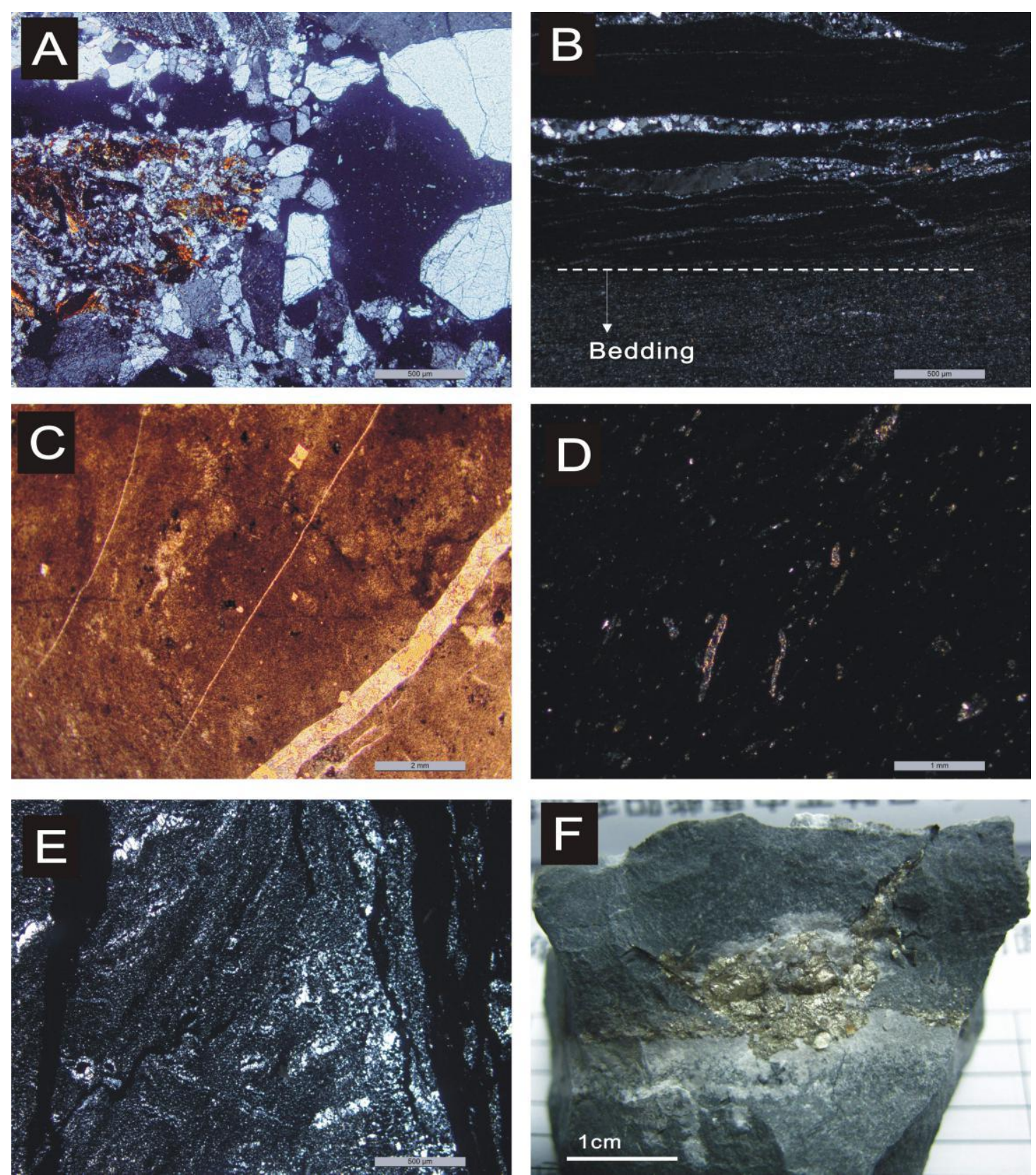

Figure 4. Photomicrographs of siliceous and black shale samples of the LFm:

A Geopetal structure containing micro-crystalline quartz, meso-crystalline quartz and mega-crystalline quartz. Crossed polars; bar scale $-500 \mu \mathrm{m}$. B Close-up of mesocrystalline quartz, showing the characteristic irregular crystal boundaries. Crossed polars; bar scale $-500 \mu \mathrm{m}$. C Pseudo-parallel mega-crystalline quartz veins. Crossed polars; bar scale $-2 \mu \mathrm{m}$. D Sporadic pyrite and deposition of organic matter within black shale of HSBY601. Crossed polars; bar scale $-1 \mu \mathrm{m}$. E Drill hole with fine-grains pyrite aggregates in dark matrix of quartz, adularia and chlorite of black shale. Orbicular and nodular structure of black shale, Sharp-clast within the black shale: Crossed polars; bar scale -1. F Fine-grains and undeformed pyrite with the siliceous rock of HSBY307. 

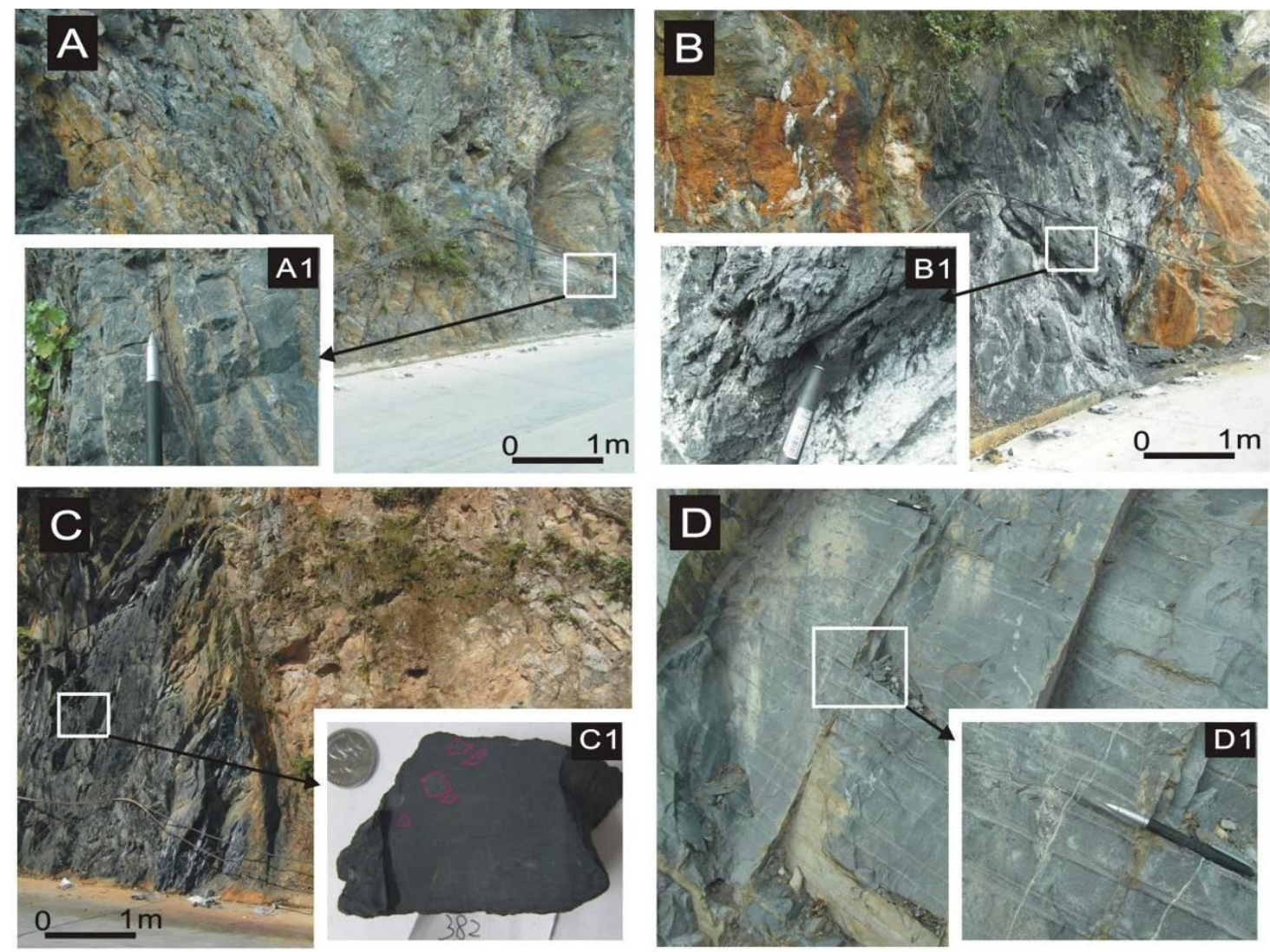

Figure 5. Field photographs of the LFm of Huoshibian section. A Dark gray to black siliceous rock of Series 6. A1 Bedding siliceous rock. B and B1 black colored stone like coal. C Laminated black shale of Series 3, steep schistosity showing strong N-S compression. C1 Sharp clast within black shale of HSBY 382 sample. D and D1 Horizontal bedding dolomitic limestone with a few calcite veins. 

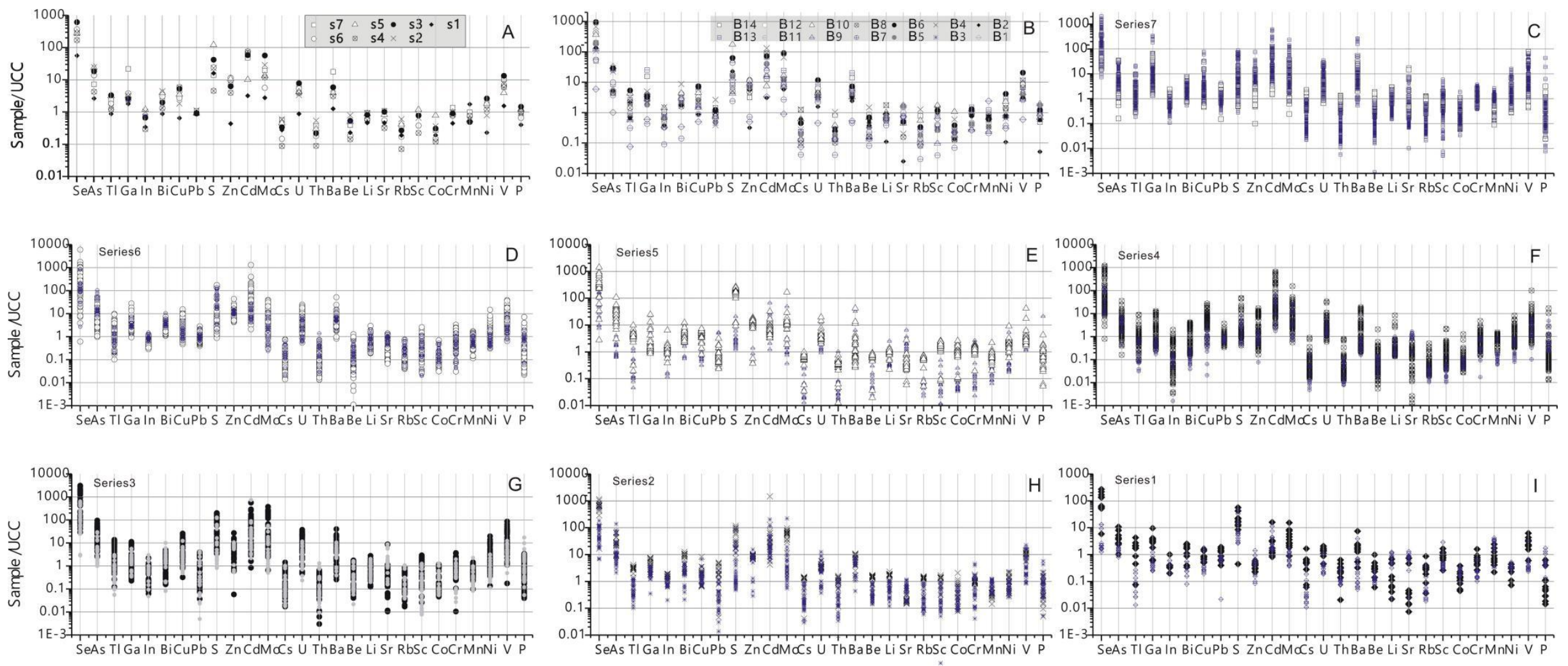

Figure 6 Enrichment patterns of elements of $14^{\text {th }}$ Bed of the LFm. 


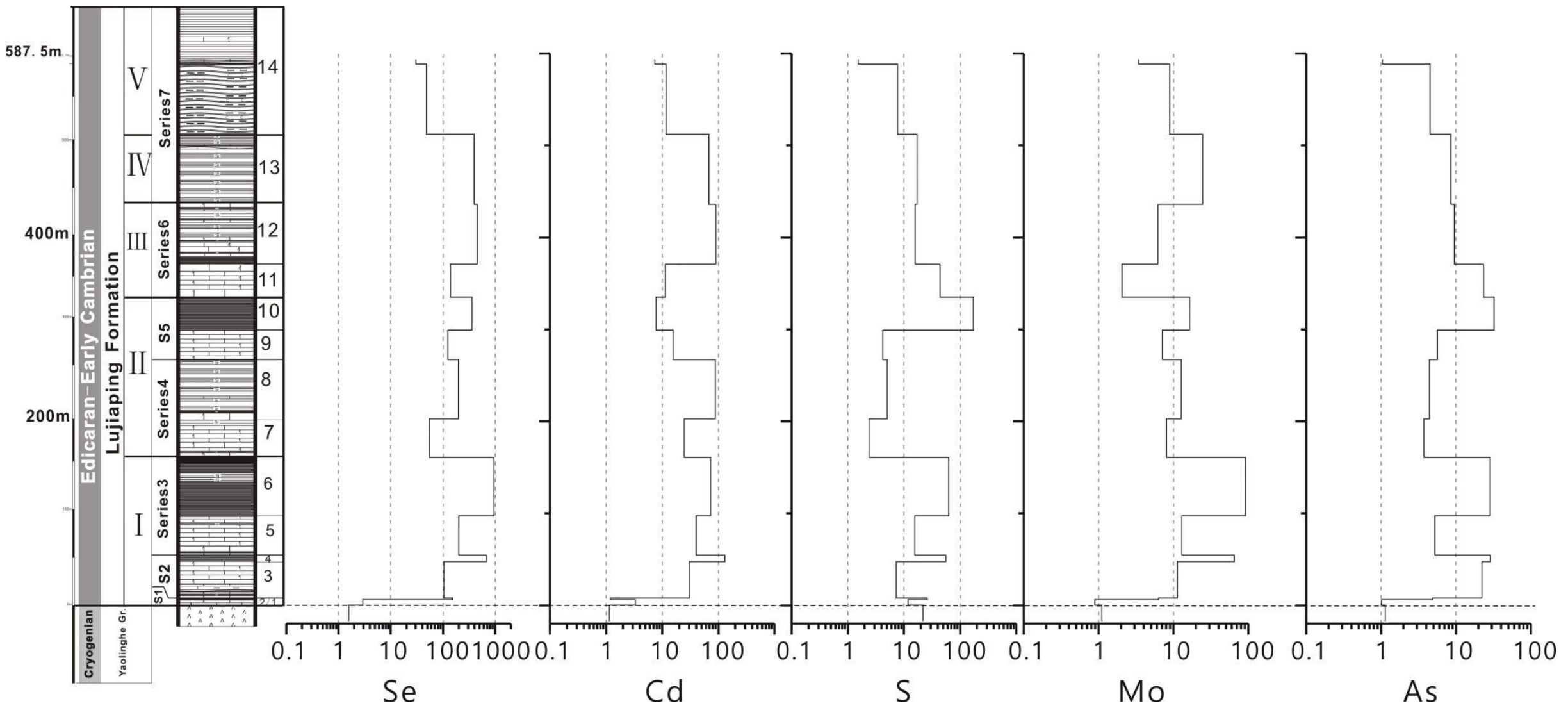

32 Figure 7. A Distribution and enrichment patterns of Se, Cd, Mo, As and S (CC $>10)$ of of $14^{\text {th }}$ Bed of the LFm. 

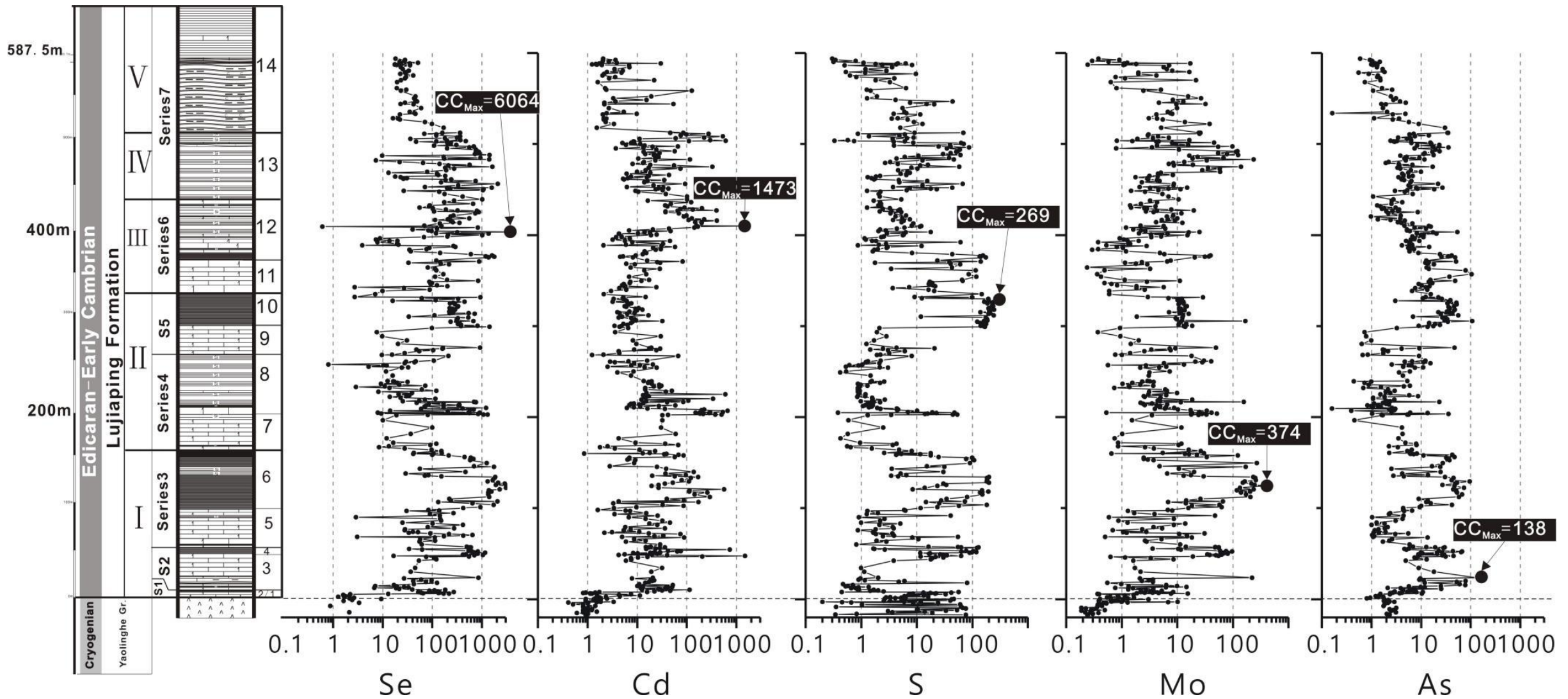

34 Figure 7. B Distribution and enrichment patterns of $\mathrm{Se}, \mathrm{Cd}, \mathrm{Mo}, \mathrm{As}$ and $\mathrm{S}(\mathrm{CC}>10)$ of $14^{\text {th }} \mathrm{Bed}$ of the $\mathrm{LFm}$. 

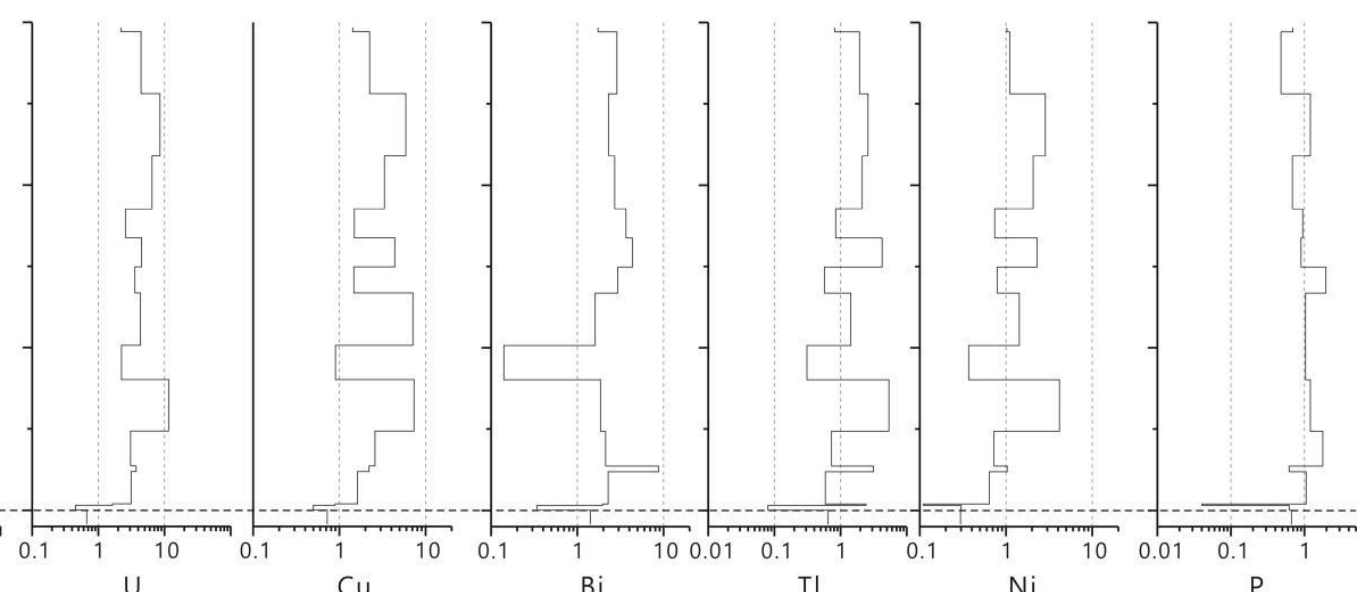

\footnotetext{
Figure 8. A Distribution and enrichment patterns of elements $(10>C C>1)$ of $14^{\text {th }}$ Bed of the LFm.
}
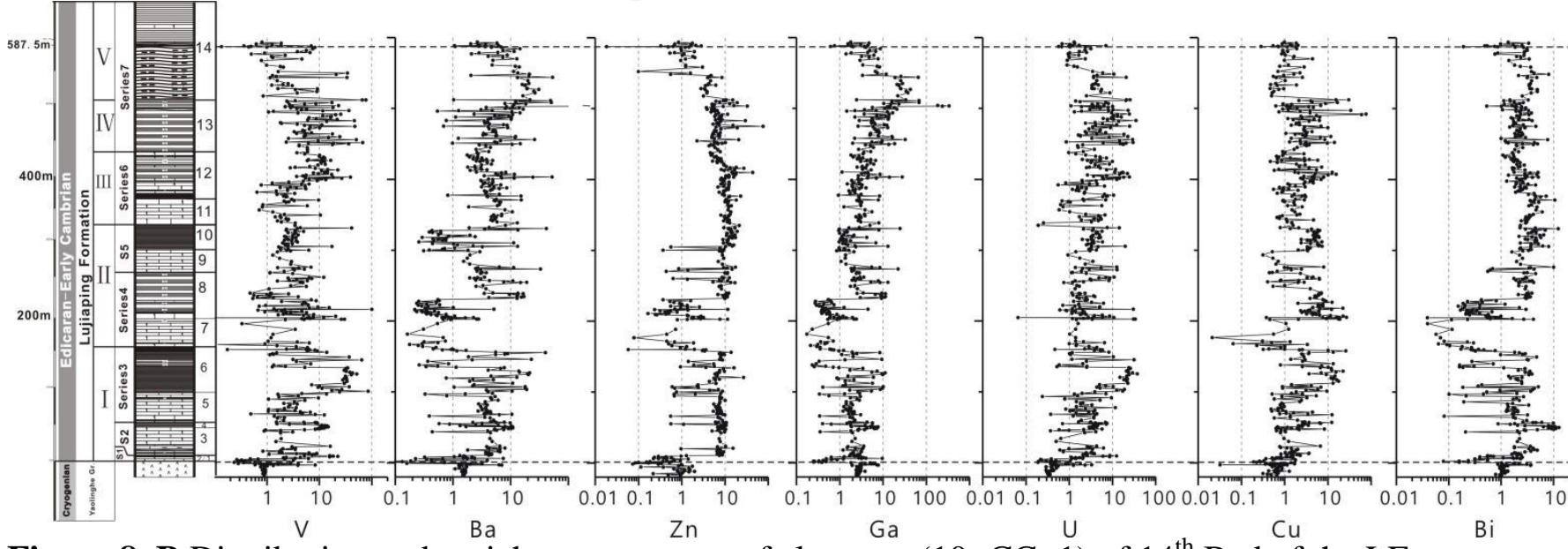

38 Figure 8. B Distribution and enrichment patterns of elements $(10>C C>1)$ of $14^{\text {th }}$ Bed of the LFm. 


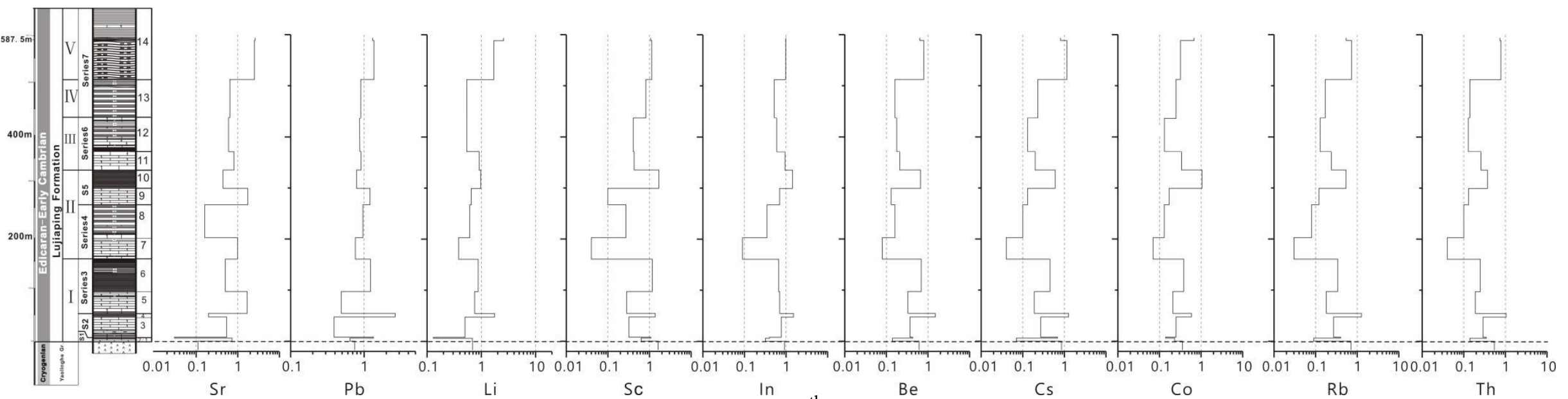

Figure 9. A Distribution and enrichment patterns of elements $(\mathrm{CC}<1)$ of $14^{\text {th }}$ Bed of the LFm.

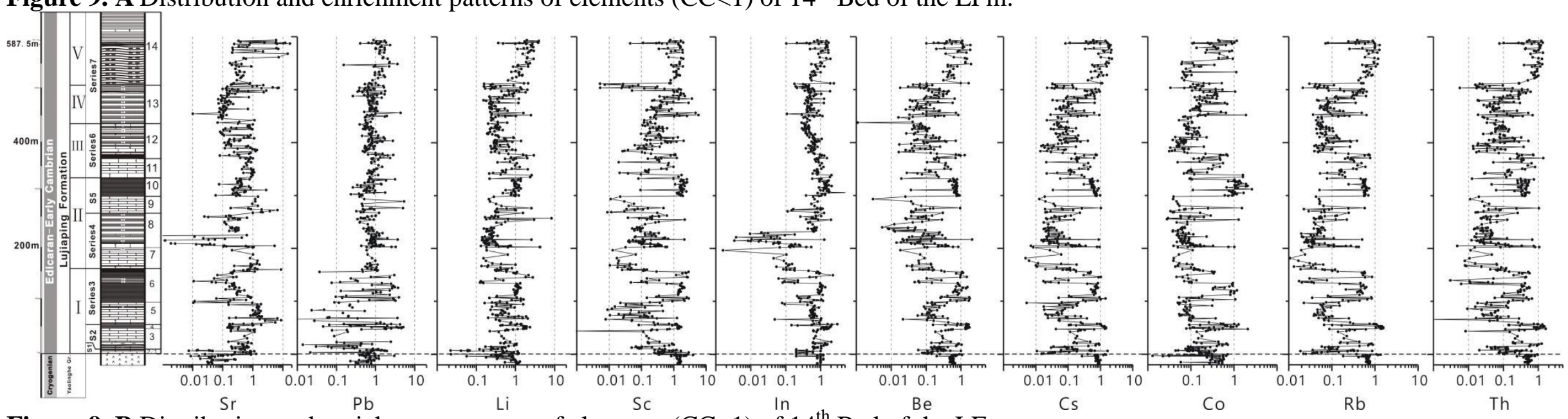



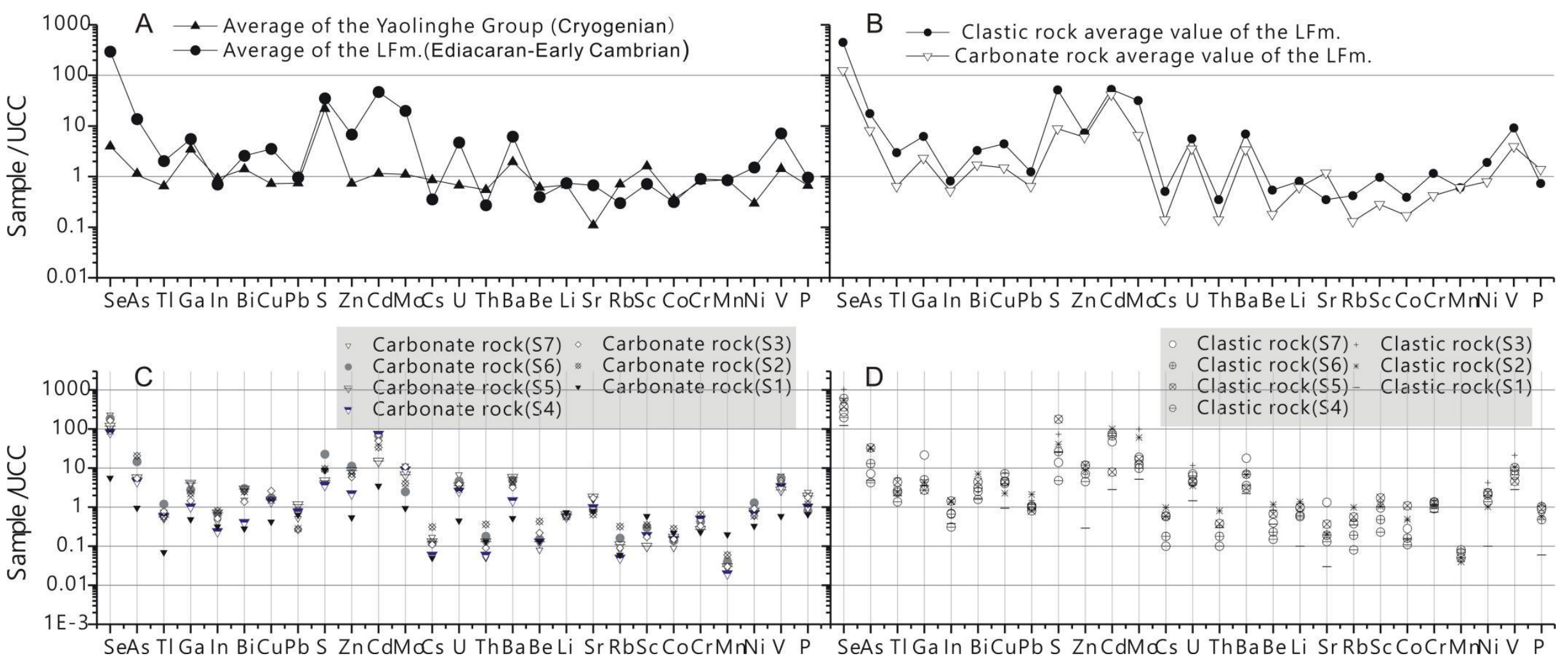

44 Figure 10. Enrichment patterns of elements of carbonate and clastic rocks of $7^{\text {th }}$ series of the LFm. 

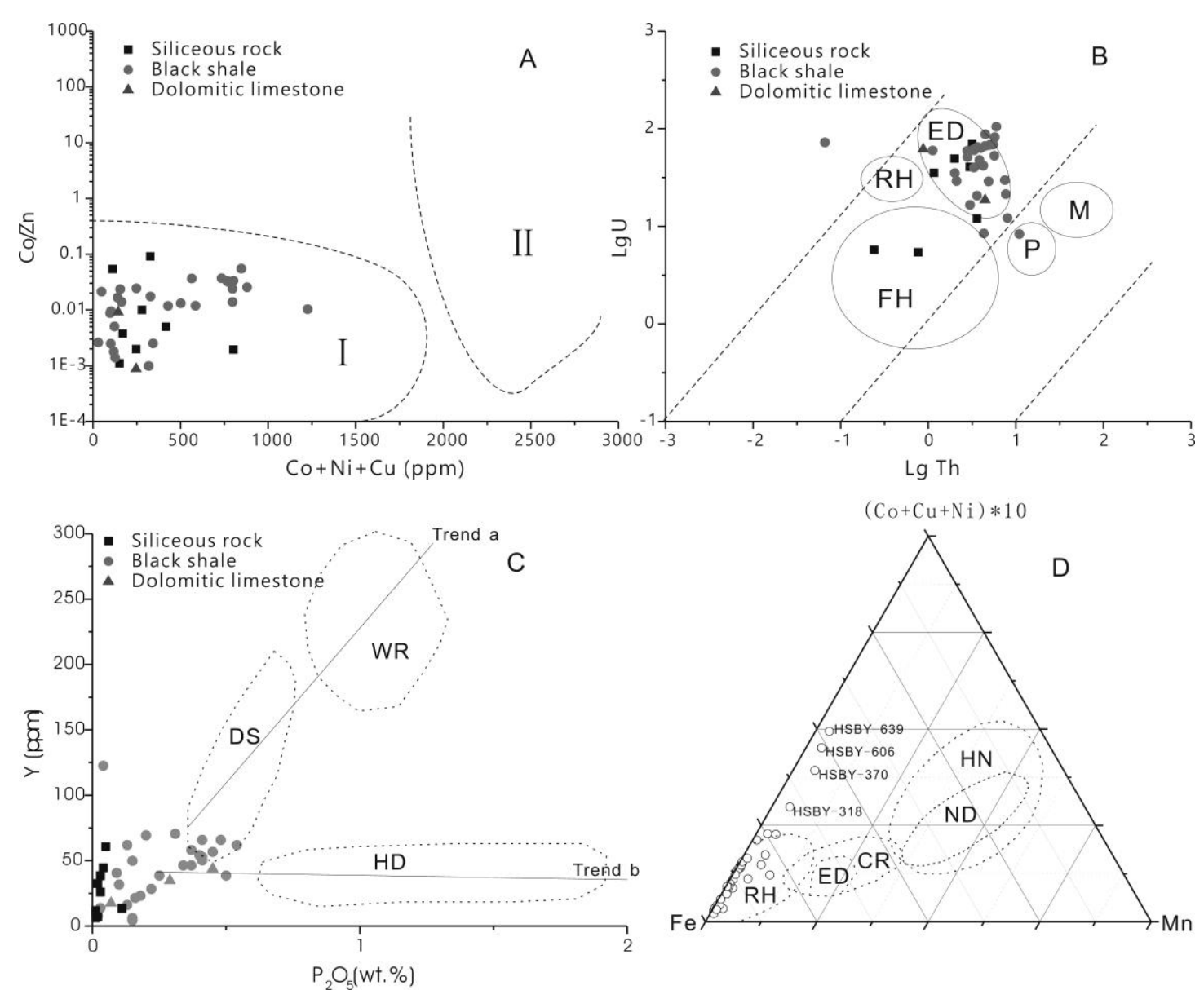

Figure 11. A Scheme of $\mathrm{Co} / \mathrm{Zn}$ vs. $(\mathrm{Co}+\mathrm{Ni}+\mathrm{Cu})$ from (Boström et al., 1973). $\mathbf{I}=$ Hydrothermal crust; $\mathbf{I I}=$ Hydrogenous sediment. B LgU vs. LgTh diagram (from Rona, 1978) of 40 anomalous Se-enrichment samples of the LFm. ED=Eastern Pacific Ocean Hydrothermal Depostion. RH=Red Ocean Hot Brine Hydrothermal Sedimentary. $\mathbf{F H}=$ Fossil Hydrothermal Sedimentary. $\mathbf{P}=$ Pain Ocean. $\mathbf{M}=$ Manganese area. $\mathbf{C ~} \mathrm{P}_{2} \mathrm{O}_{5}$ (wt.\%) versus $\mathrm{Y}$ (ppm) diagram for different types of sediments (after Marchig et al. 1982). a, trend line for modern hydatogen sediments; $b$, trend line for modern hydrothermal sediments. DS, field of deep-sea sediments. WR, field for diagenic-type metalliferous sediments. and HD, field for hydrothermal-type metalliferous sediments. $\mathbf{D}(\mathrm{Cu}+\mathrm{Co}+\mathrm{Ni}) \times 10$-Fe-Mn diagram for sediment rocks of different origin(s) (modified from Rona 1978). ED, East Pacific hydrothermal metalliferous sediment. CR, hydrothermal ferromanganese crust sediment. HD, hydrothermal sedimentation area. RH, Red Sea hydrothermal sedimentation area. HN, hydrous sediment. ND, hydrous nodule. 

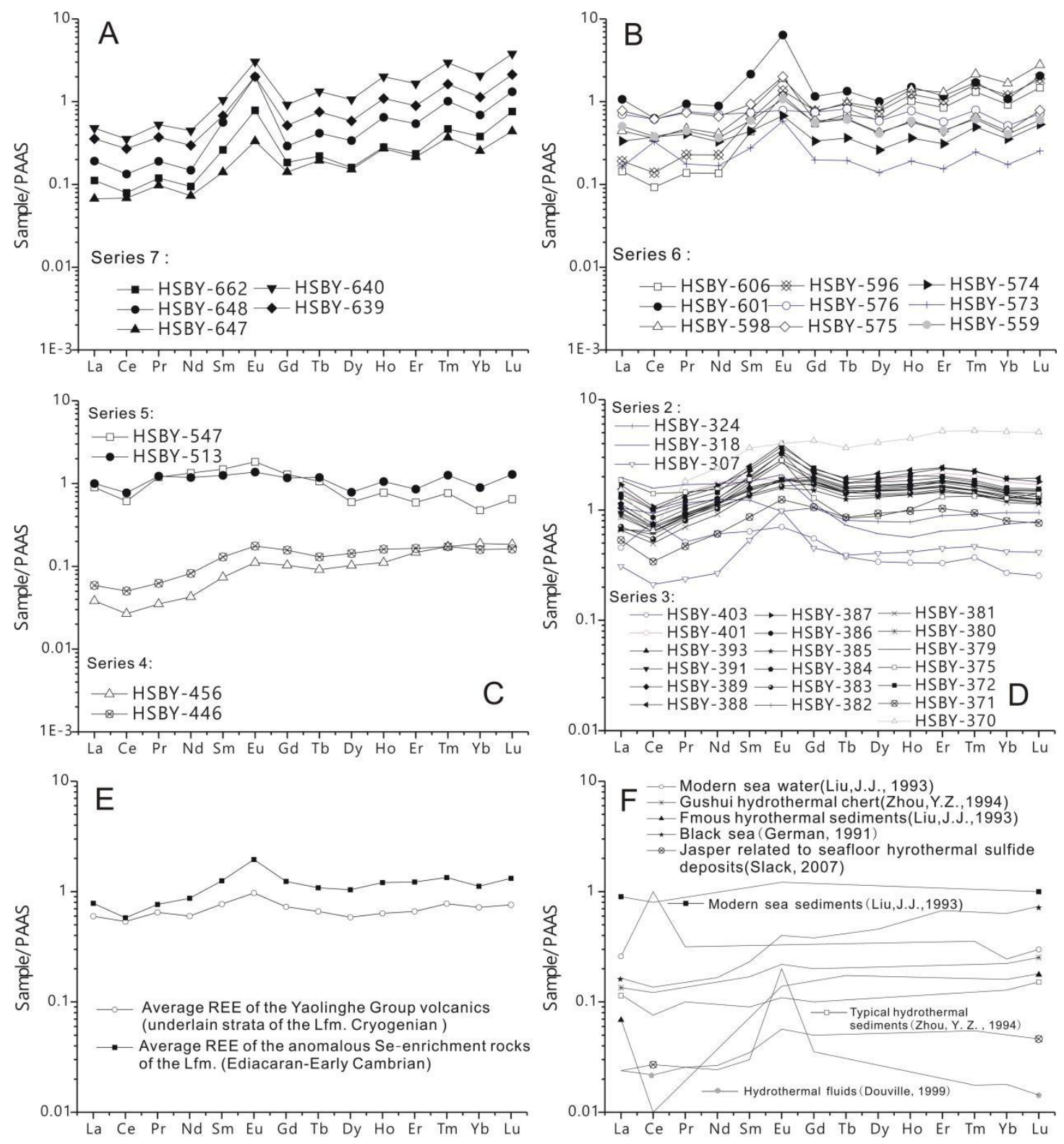

Figure 12. Shale-nomalized (PAAS) REE distribution of 40 anomalous Se-enrichment samples of the LFm. 


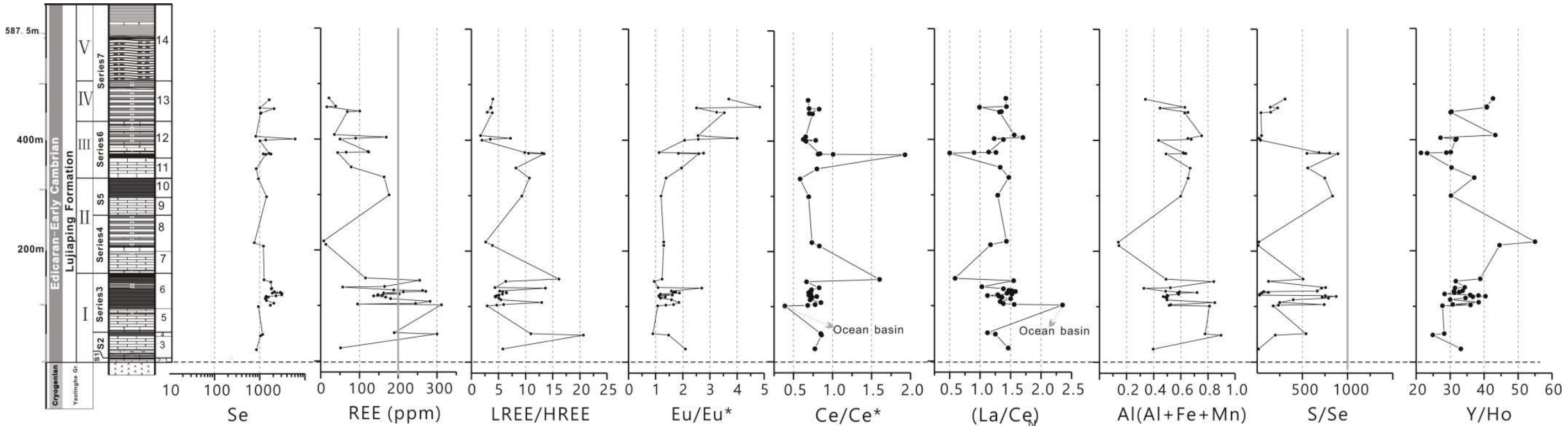

64 Figure 13 Distribution of REE of 40 anomalous Se-enrichment samples of the LFm. 

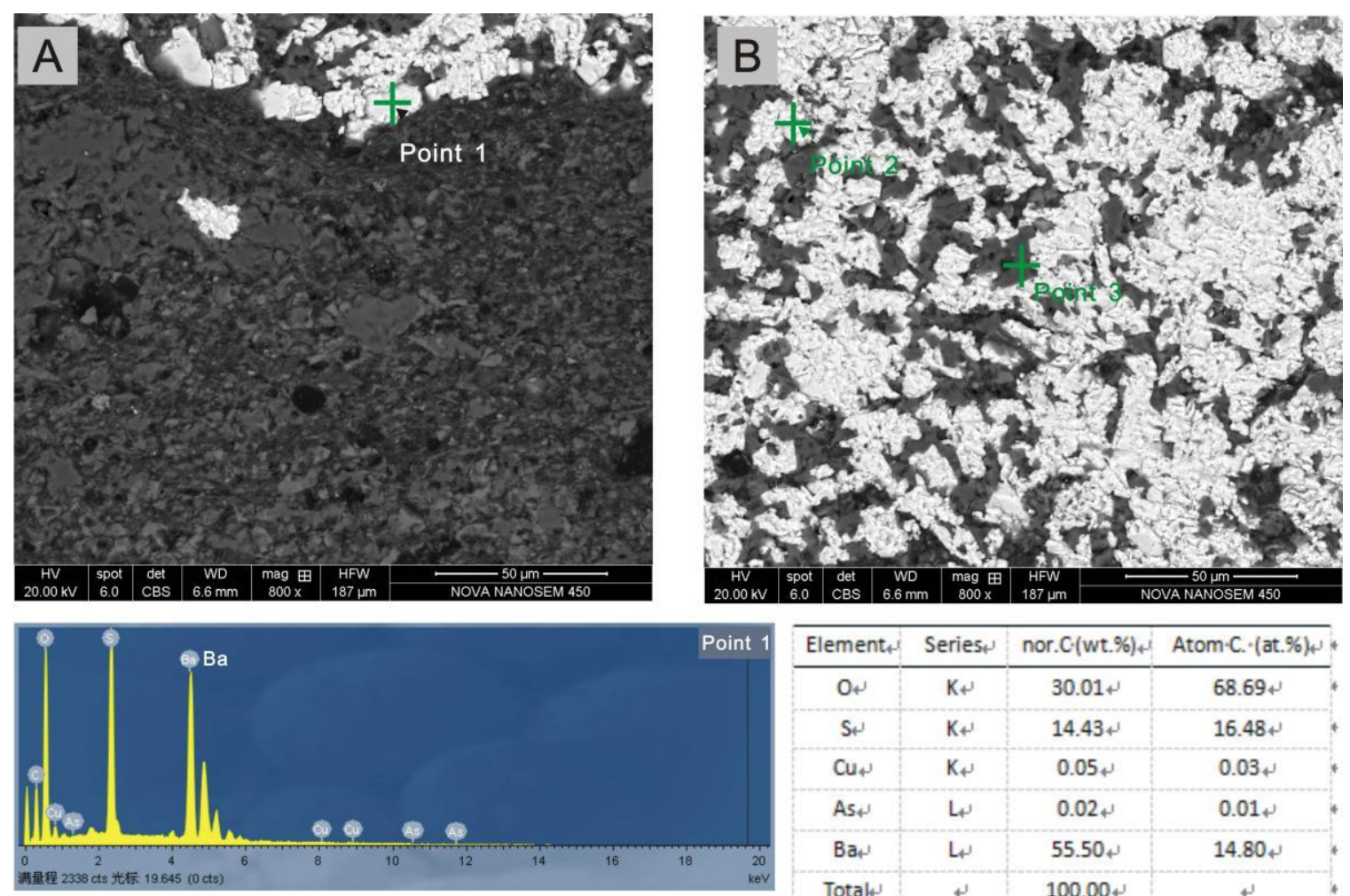

\begin{tabular}{|c|c|c|c|}
\hline Elements & Series & nor.C.(wt.\%) & Atom-C. (at.\%) \\
\hline O & $\mathrm{K}$ & 30.01 & 68.69 \\
\hline $\mathrm{S}$ & $\mathrm{K}$ & 14.43 & 16.48 \\
\hline $\mathrm{Cu}$ & $\mathrm{K}$ & 0.05 & 0.03 \\
\hline As & $\mathrm{L}$ & 0.02 & 0.01 \\
\hline Ba & $\mathrm{L}$ & 55.50 & 14.80 \\
\hline Total & & 100.00 & \\
\hline
\end{tabular}

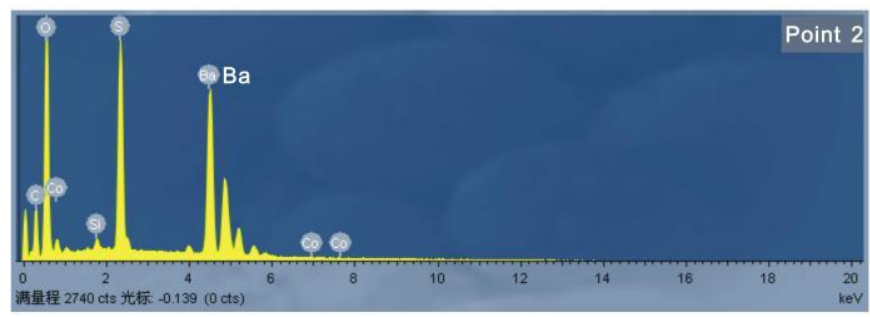

\begin{tabular}{|c|c|c|c|}
\hline Element & Series & nor.C.(wt.\%) & Atom.C.(at.\%) \\
\hline $\mathrm{O}$ & $\mathrm{K}$ & 30.50 & 69.12 \\
\hline $\mathrm{S}$ & $\mathrm{K}$ & 14.40 & 16.28 \\
\hline $\mathrm{C}$ & $\mathrm{K}$ & 0.16 & 0.10 \\
\hline Ba & $\mathrm{L}$ & 54.94 & 14.50 \\
\hline Totak & & 100.00 & \\
\hline
\end{tabular}

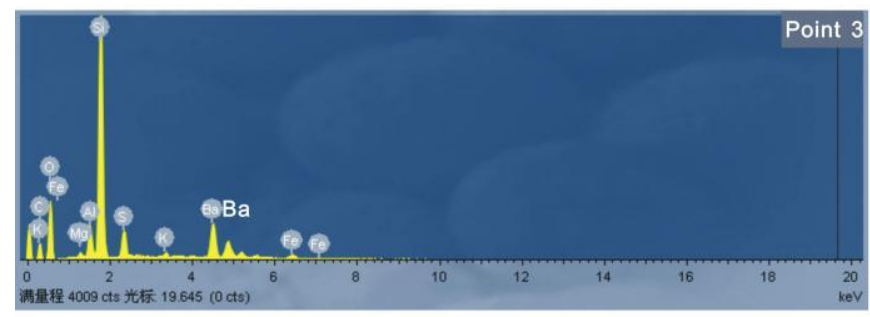

\begin{tabular}{|c|c|c|c|}
\hline Element & Series & nor.C.(wt.\%) & Atom C. (at.\%) \\
\hline $\mathrm{O}$ & $\mathrm{K}$ & 26.49 & 48.04 \\
\hline $\mathrm{Mg}$ & $\mathrm{K}$ & 0.64 & 0.76 \\
\hline $\mathrm{Al}$ & $\mathrm{K}$ & 3.81 & 4.10 \\
\hline $\mathrm{Si}$ & $\mathrm{K}$ & 34.10 & 35.22 \\
\hline $\mathrm{S}$ & $\mathrm{K}$ & 4.94 & 4.47 \\
\hline $\mathrm{K}$ & $\mathrm{K}$ & 0.78 & 0.58 \\
\hline $\mathrm{Fe}$ & $\mathrm{K}$ & 2.15 & 1.12 \\
\hline $\mathrm{Ba}$ & $\mathrm{L}$ & 27.10 & 5.72 \\
\hline Total & & 100.00 & \\
\hline
\end{tabular}

66 Figure 14 X-ray energy spectrometric analysis for black shale (HSBY 601) minerals of 67 Bed 12 of the LFm. 
Table 1 The detailed description of five Member of the LFm of Ziyang County of southern Shaanxi Province, China.

Abbreviation: LFm=Lujiaping Formation, M.=Member, s.=series, T.= Thickness, B.=Bed, Lith.=Lithology. CLR=Clastic rock, CAR=Carbonate rock.

\begin{tabular}{|c|c|c|c|c|c|c|}
\hline M. & S. & T. & B. & Sample & Lith. & Description \\
\hline $\mathrm{V}\left(5^{\text {th }} \mathrm{M}\right)$ & \multirow[b]{2}{*}{ s 7} & ca.300m & B 14 & HSBY682-728 & CLR & Gray or gray-black shale interbedded with gray calcareous shale, limestone and stone like coal. \\
\hline $\mathrm{IV}\left(4^{\text {th }} \mathrm{M}\right)$ & & $77.1 \mathrm{~m}$ & B 13 & HSBY632-681 & CLR & $\begin{array}{l}\text { Black or light-green siliceous rock (Fig. } 5 \mathrm{~A} \text { ) interbedded with gray or black-gray dolomitic } \\
\text { limestone, limestone and witherite ore (ca. } 2 \mathrm{~m} \text {-thick). }\end{array}$ \\
\hline \multirow[t]{2}{*}{$\mathrm{III}\left(3^{\mathrm{rd}} \mathrm{M}\right)$} & \multirow[t]{2}{*}{ s 6} & \multirow[t]{2}{*}{$95.5 \mathrm{~m}$} & B 12 & HSBY573-631 & CLR & $\begin{array}{l}\text { Black or light-green siliceous rock interbedded with gray or black-gray dolomitic limestone and } \\
\text { black shale. }\end{array}$ \\
\hline & & & B 11 & HSBY551-571 & CAR & Gray or black-gray dolomitic limestone (Fig. 5D). \\
\hline \multirow{4}{*}{$\|\left(2^{\text {nd }} M\right)$} & \multirow{2}{*}{ s 5} & \multirow{2}{*}{$70.4 \mathrm{~m}$} & B 10 & HSBY513-548 & CLR & Black shale interbedded with siliceous rock (ca.0.3 m-thick) and limestone (ca. 1-m-thick). \\
\hline & & & B 9 & HSBY497-512 & CAR & Gray or gray-black dolomitic limestone. \\
\hline & \multirow{2}{*}{ s 4} & \multirow{2}{*}{$106.8 \mathrm{~m}$} & B 8 & HSBY431-495 & CLR & $\begin{array}{l}\text { Black or gray-black siliceous rock interbedded with dolomitic limestone and limestone (ca. } \\
0.9 \mathrm{~m} \text {-thick). }\end{array}$ \\
\hline & & & B 7 & HSBY416-430 & CAR & $\begin{array}{l}\text { Black or gray-black dolomitic limestone interbedded with siliceous rock, and limestone (ca. } \\
0.9 \mathrm{~m} \text {-thick) and black shale (ca. } 0.2 \mathrm{~m} \text {-thick). }\end{array}$ \\
\hline \multirow{5}{*}{$\mathrm{I}\left(1^{\mathrm{st}} \mathrm{M}\right)$} & \multirow[b]{2}{*}{ s 3} & \multirow[b]{2}{*}{$107.2 \mathrm{~m}$} & В 6 & HSBY367-415 & CLR & $\begin{array}{l}\text { Black shale (Fig. 5B and C) interbedded with black siliceous rock, stone-like coal and dolomitic } \\
\text { limestone. }\end{array}$ \\
\hline & & & В 5 & HSBY331-366 & CAR & $\begin{array}{l}\text { Dolomitic limestone interbedded with black siliceous rock (ca.1.1-m-thick) and Black shale (ca. } \\
0.7 \text {-m-thick).Those black shale and siliceous rock overlying the black or gray dolomitic limestone } \\
\text { which intercalated with black-gray mud siliceous rock (ca. } 0.1 \mathrm{~m} \text {-thick) and gray limestone (ca. } \\
0.2 \mathrm{~m} \text {-thick). }\end{array}$ \\
\hline & \multirow[b]{2}{*}{ s 2} & \multirow[b]{2}{*}{$46.6 \mathrm{~m}$} & B 4 & HSBY315-329 & CLR & Laminated black shale. \\
\hline & & & В 3 & HSBY287-315 & CAR & $\begin{array}{l}\text { Light green dolomitic limestone interbedded with siliceous rock and yellow or light gray mud } \\
\text { limestone. }\end{array}$ \\
\hline & s 1 & $7.9 \mathrm{~m}$ & B 2 & HSBY279-286 & CLR & Black shale. \\
\hline
\end{tabular}


Table 2 The average and range contents of Carbonates and Clastics' major elements from the LFm of southern Shaanxi Province (unit: wt\% )

2 Abbreviations : LFm=Lujiaping Formation, UCC=Upper Continental Crust, Avg.=average, Std.=Stdevp.

\begin{tabular}{|c|c|c|c|c|c|c|c|c|c|c|c|c|}
\hline The LFm & Sample No. & $\mathrm{SiO}_{2}$ & $\mathrm{Al}_{2} \mathrm{O}_{3}$ & $\mathrm{CaO}$ & $\mathrm{Fe}_{2} \mathrm{O}_{3}$ & $\mathbf{K}_{2} \mathrm{O}$ & MgO & $\mathrm{Na}_{2} \mathrm{O}$ & $\mathrm{TiO}_{2}$ & MnO & $\mathbf{P}_{2} \mathrm{O}_{5}$ & LOI \\
\hline \multirow{4}{*}{ Carbonates } & Min & 0.11 & 0.07 & 8.90 & 0.04 & nd. & 0.65 & 0.02 & nd. & nd. & 0.01 & 8.30 \\
\hline & $\operatorname{Max}$ & 44.85 & 8.89 & 47.43 & 4.32 & 2.75 & 21.39 & 3.20 & 0.42 & 0.32 & 3.41 & 46.43 \\
\hline & Std. & 9.07 & 1.58 & 6.93 & 0.75 & 0.51 & 4.24 & 0.88 & 0.08 & 0.06 & 0.43 & 6.16 \\
\hline & Avg. & 14.44 & 1.73 & 27.49 & 0.72 & 0.51 & 14.71 & 1.30 & 0.08 & 0.05 & 0.20 & 39.18 \\
\hline \multirow{4}{*}{ Clastics } & Min & 44.68 & 0.13 & 0.02 & 0.47 & nd. & 0.05 & 0.01 & nd. & 0.01 & nd. & 0.22 \\
\hline & $\operatorname{Max}$ & 98.04 & 20.13 & 8.94 & 11.17 & 5.71 & 27.27 & 6.81 & 1.53 & 0.20 & 6.94 & 31.69 \\
\hline & Std. & 12.09 & 5.76 & 1.42 & 1.44 & 1.53 & 0.85 & 0.90 & 0.33 & 0.04 & 0.67 & 3.94 \\
\hline & Avg. & 78.92 & 6.26 & 0.83 & 2.77 & 1.82 & 1.14 & 1.40 & 0.31 & 0.07 & 0.12 & 6.21 \\
\hline \multicolumn{2}{|c|}{$\mathbf{U} \mathbf{C C}^{\mathbf{a}}$} & 30.80 & 8.04 & 3.00 & 3.50 & 2.80 & 1.33 & 2.89 & 0.41 & 0.08 & 0.16 & - \\
\hline \multicolumn{2}{|c|}{ Shale $^{b}$} & 7.30 & 8.00 & 2.21 & 4.70 & 2.66 & 1.50 & 0.96 & 0.46 & 0.09 & 0.07 & - \\
\hline \multicolumn{2}{|c|}{ Carbonate $^{b}$} & 2.40 & 0.42 & 30.23 & 0.38 & 0.27 & 4.70 & 0.04 & 0.04 & 0.11 & 0.04 & - \\
\hline \multicolumn{2}{|c|}{ Franciscan siliceous rock } & 92.30 & 1. 31 & 0.11 & 2.63 & 0.35 & 0.28 & 0.11 & 0.09 & 0.53 & 0.03 & - \\
\hline
\end{tabular}

a Taylor and Mclennan, 1985;

b Turekian et al., 1961

c Yamamoto et al,1987

"nd"=Below the detection limit. 
Table 3 The variation of the Se, Cd, Mo, S and As contents of $14^{\text {th }}$ Bed of the LFm of southern Shaanxi Province(unit: ppm )

Abbreviations : M.=Member; B.=Bed; UCC=Upper Continental Crust, Avg.=average, Std.=Stdevp. nd.=Below the detection limit.

\begin{tabular}{|c|c|c|c|c|c|c|c|c|c|c|c|c|c|c|c|c|c|c|c|c|c|}
\hline \multirow[t]{2}{*}{ M. } & \multirow[t]{2}{*}{ Bed. } & \multicolumn{4}{|c|}{ Se } & \multicolumn{4}{|c|}{ Cd } & \multicolumn{4}{|c|}{ Mo } & \multicolumn{4}{|c|}{$\mathbf{S}$} & \multicolumn{4}{|c|}{ As } \\
\hline & & Min & Max & Avg. & Std. & Min & Max & Avg. & $S t d$ & Min & Max & Avg. & Std. & Min & Max & vg. & Std. & Min & Iax & Avg. & $S t d$ \\
\hline $\mathrm{V}$ & & 1 & 18 & 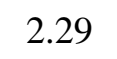 & 1 & 2 & 12 & 3 & 8 & 37 & 57 & 9 & 9 & 105 & 40 & 2807 & 31 & 12 & - & 14 & 12.84 \\
\hline \multirow{2}{*}{ III } & B 12 & 0.03 & 303 & 21.72 & 43.26 & $n d$. & 129 & 8.52 & 18.12 & na. & 60 & 10.16 & 13.11 & 303 & 60780 & 5800 & 13458 & 1.45 & 81 & 4.58 & 16.70 \\
\hline & B 11 & 14 & 44 & 9.25 & 11.18 & 0.43 & 8 & 1.56 & 1.65 & 0.35 & 17 & 4.01 & 4.16 & 618 & 49790 & 15435 & 14108 & 11.43 & 156 & .87 & 37.00 \\
\hline \multirow{2}{*}{ II } & B 8 & 0.04 & 65 & 9.90 & 15.92 & 0.25 & 65 & 8.70 & 15.09 & 0.85 & 235 & 18.96 & 32.44 & 146 & 18850 & 1771 & 3747 & $n d$. & 53 & 6.61 & 8.63 \\
\hline & B 7 & 0.42 & 8 & 2.75 & 2.27 & 0.18 & 1 & 2.43 & 1.94 & 1.12 & 40 & 12.10 & 12.34 & 148 & 2822 & 840 & 73 & $n d$. & 12 & 5.62 & 3.60 \\
\hline \multirow{3}{*}{ I } & B 6 & 1.45 & 154 & 49.20 & 43.78 & 0.08 & 55 & 7.06 & 9.60 & 0.98 & 562 & 136.66 & 149.03 & 1210 & 70010 & 22045 & 23 & 3.80 & 144 & 42.81 & 32.86 \\
\hline & $\mathrm{B}$ & 4 & 32 & 10 & 1 & $n d$ & 7 & 3 & 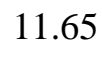 & $n d$. & 84 & 19.39 & 2 & 7 & 40 & . & 6 & 1.51 & 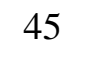 & 7.82 & 10 \\
\hline & 1 & 0.00 & 1 & (50 & 0.26 & 0.09 & 1.11 & 0.3 & 0.2 & $0.0 J$ & $J$ & 1.04 & 0.00 & 929 & 16330 & $41 J 3$ & 4479 & $n d$. & 4 & 2.11 & 0.86 \\
\hline \multirow{2}{*}{\multicolumn{2}{|c|}{$\begin{array}{c}\text { The LFm. } \\
\text { UCC }^{\text {a }}\end{array}$}} & 0.03 & 303 & 16.40 & 27.41 & $n d$. & 144 & 4.34 & 12.94 & $n d$. & 562 & 29.53 & 69.81 & 96 & 94300 & 11546 & 19760 & $n d$. & 207 & 20.12 & 26.78 \\
\hline & & & & 0.05 & & & & 0.098 & & & & 1.0 & & & & $4<0$ & & & & 1.5 & \\
\hline \multicolumn{2}{|c|}{ Shale $^{b}$} & & & 0.60 & & & & 0.3 & & & & 2.60 & & & & 2400 & & & & 13 & \\
\hline
\end{tabular}

a Taylor and Mclennan, 1985;

b Turekian et al., 1961 


\begin{tabular}{|c|c|c|c|c|c|c|}
\hline \multirow[b]{2}{*}{ Country } & \multirow[b]{2}{*}{ Location } & \multirow[b]{2}{*}{ Se-Ore Industry Type } & \multicolumn{4}{|c|}{ Geologic Feature } \\
\hline & & & Ore-containing Rock & $\begin{array}{c}\text { Mineral } \\
\text { Species }\end{array}$ & $\begin{array}{c}\text { Se Grade } \\
(\text { ppm) }\end{array}$ & Scale \\
\hline Bolivia & Puhakka & Altered Rock Type & Altered Rock & $\mathrm{Se}$ & $>10$ & Small \\
\hline \multirow{2}{*}{ Canada } & Noranda & $\begin{array}{c}\text { Volcanic Hydrothermal } \\
\text { Type }\end{array}$ & Volcanics & Se, $\mathrm{Cu} 、 \mathrm{Ni}$ & 64 & Supper-Large \\
\hline & Fiynn Furlong & $\begin{array}{c}\text { Volcanic Hydrothermal } \\
\text { Type }\end{array}$ & Volcanics & $\mathrm{Se}, \mathrm{Cu} 、 \mathrm{Ni}$ & 64 & Supper-Large \\
\hline Philippines & Atlas & Magma Type & Granodioritic & $\mathrm{Se}, \mathrm{Cu}$ & $>10$ & Large \\
\hline \multirow{2}{*}{ Chile } & La Escondida & Magma Type & Graniteprophyry & $\mathrm{Se}, \mathrm{Cu}$ & $>10$ & Large \\
\hline & Chuquicamata & Magma Type & Graniteprophyry & $\mathrm{Se}, \mathrm{Cu}$ & $>10$ & Large \\
\hline \multirow{2}{*}{ America } & Bingham & Magma Type & Graniteprophyry & $\mathrm{Se}, \mathrm{Cu}$ & 21.5 & Large \\
\hline & Twin Buttes & Magma Type & Graniteprophyry & $\mathrm{Se}, \mathrm{Cu}$ & 21.5 & Large \\
\hline Zaire & Kolwezi & Clastic Type & $\begin{array}{l}\text { Carbonic Sandstone. } \\
\text { Carbonnic Shale }\end{array}$ & $\mathrm{Se}$ & $>10$ & Large \\
\hline \multirow[t]{2}{*}{ Zambia } & Shuifu In La & Clastic Type & $\begin{array}{c}\text { Carbonic Sandstone and } \\
\text { Shale }\end{array}$ & $\mathrm{Se}$ & $>10$ & Large \\
\hline & Nchanga & Clastic Type & $\begin{array}{c}\text { Carbonic and } \\
\text { Carbonnic Shale }\end{array}$ & $\mathrm{Se}$ & $>10$ & Large \\
\hline
\end{tabular}




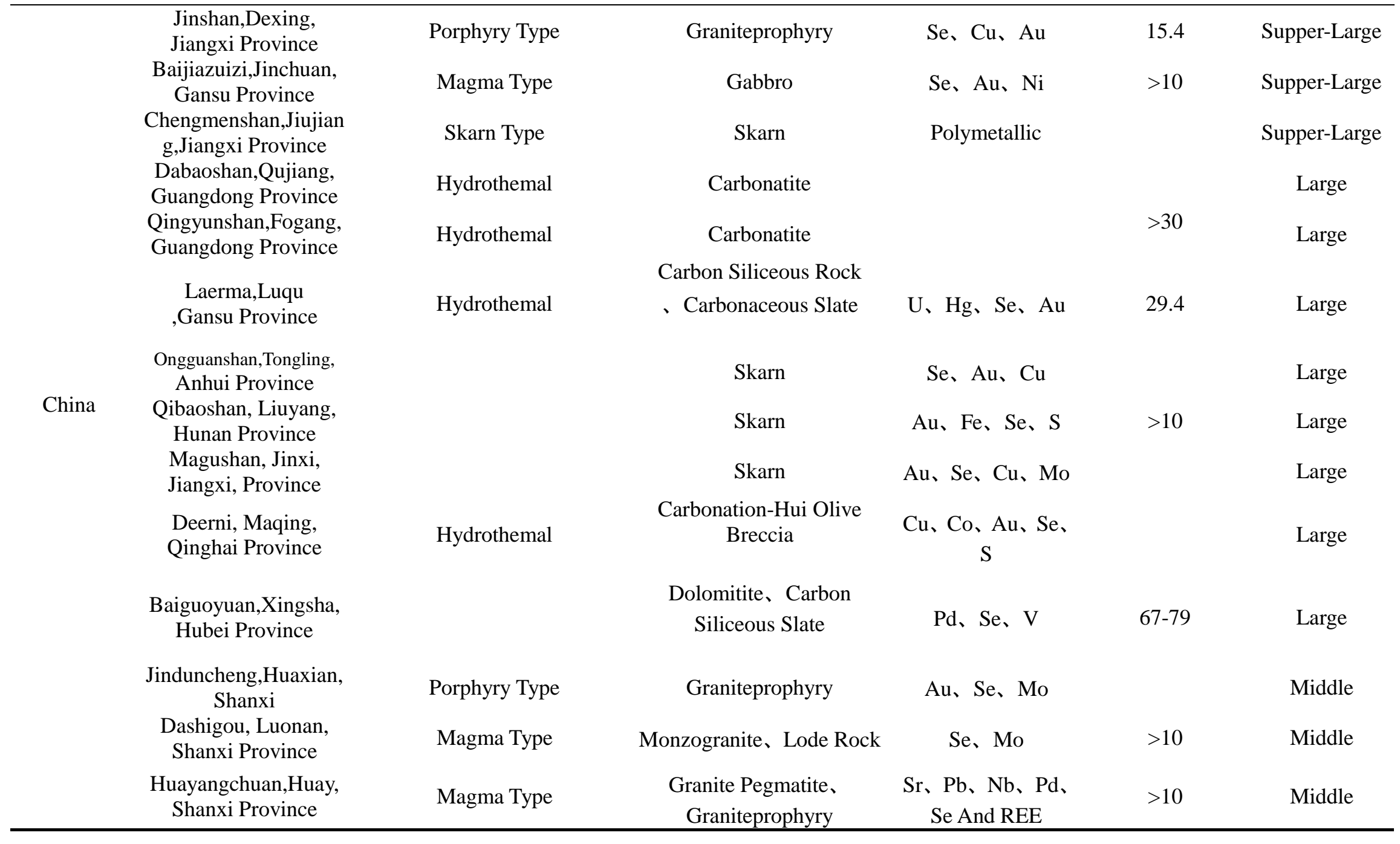




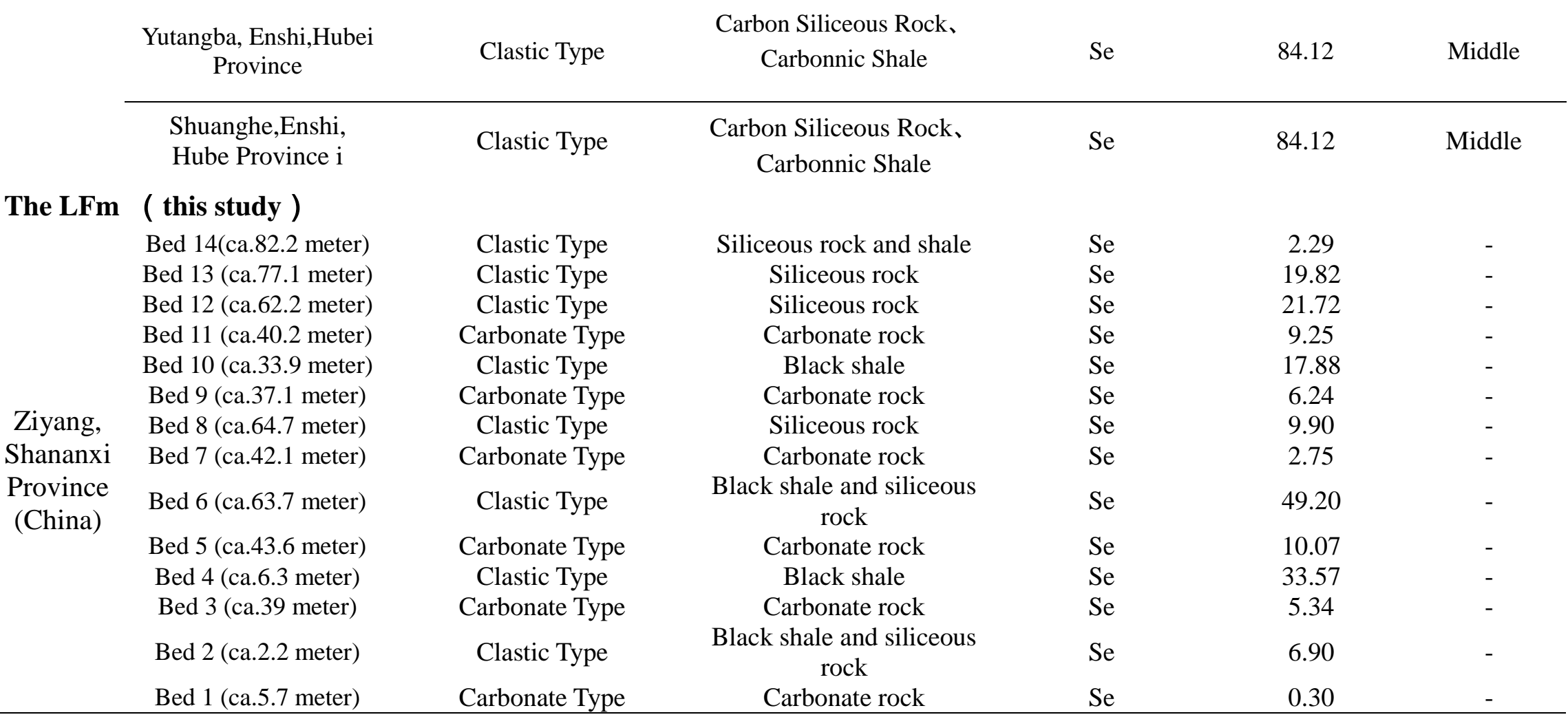

\section{The LFm ( this study )}

arbon Siliceous Rock、

bon Siliceous Rock

\author{
Carbonnic Shale
}

ceous rock and shale

Siliceous rock

Black shale

Carbonate rock

Siliceous rock

Carbonate rock

$$
\text { rock }
$$

Carbonate rock

0.30 
Table 5 Major elements of anomalous Se-enrichment samples of the LFm from Ziyang county, southern Shaanxi Province (China)(unit:\%).

Abbreviations : SR=Siliceous rock, DL=Dolomistic Limestone, BS=Black Shale, No.=Sample number.

\begin{tabular}{|c|c|c|c|c|c|c|c|c|c|c|c|c|c|c|c|c|}
\hline $\operatorname{Deepth}(\mathbf{m})$ & Member & Series & Bed & Lithology & No. & $\mathrm{SiO}_{2}$ & $\mathbf{A l}_{2} \mathbf{O}_{3}$ & $\mathrm{CaO}$ & $\mathrm{Fe}_{2} \mathrm{O}_{3}$ & $\mathbf{K}_{2} \mathbf{O}$ & MgO & $\mathrm{Na}_{2} \mathrm{O}$ & $\mathrm{TiO}_{2}$ & MnO & $\mathbf{P}_{2} \mathbf{O}_{5}$ & LOI \\
\hline 474.1 & $\operatorname{IV}\left(4^{\text {th }} M\right)$ & S 7 & B 13 & SR & HSBY-662 & 93.68 & 1.21 & 0.13 & 1.63 & 0.34 & 0.15 & 0.66 & 0.07 & 0.13 & 0.01 & 1.91 \\
\hline 459.2 & $\operatorname{IV}\left(4^{\text {th }} \mathrm{M}\right)$ & S 7 & B 13 & SR & HSBY-648 & 89.86 & 3 & 0.14 & 1.26 & 0.91 & 0.16 & 1.01 & 0.17 & 0.07 & 0.03 & 3.32 \\
\hline 458.1 & $\operatorname{IV}\left(4^{\text {th }} \mathrm{M}\right)$ & S 7 & B 13 & SR & HSBY-647 & 94.03 & 1.29 & 0.11 & 1.13 & 0.38 & 0.12 & 1.03 & 0.09 & 0.07 & 0.01 & 1.71 \\
\hline 450.3 & $\operatorname{IV}\left(4^{\text {th }} \mathrm{M}\right)$ & S 7 & B 13 & SR & HSBY-640 & 83.96 & 5.01 & 0.19 & 1.94 & 1.66 & 0.68 & 0.85 & 0.27 & 0.06 & 0.05 & 4.62 \\
\hline 449.4 & $\operatorname{IV}\left(4^{\text {th }} \mathrm{M}\right)$ & S 7 & B 13 & SR & HSBY-639 & 91.15 & 2.61 & 0.08 & 1.09 & 0.79 & 0.39 & 1.03 & 0.16 & 0.06 & 0.02 & 2.35 \\
\hline 408.2 & $\operatorname{III}\left(3^{\mathrm{rd}} \mathrm{M}\right)$ & S 6 & B 12 & DL & HSBY-606 & 13.74 & 1.49 & 25.29 & 0.34 & 0.38 & 16.22 & 2.16 & 0.07 & 0.02 & 0.45 & 39.83 \\
\hline 403.4 & $\| I I\left(3^{\text {rd }} M\right)$ & S 6 & B 12 & BS & HSBY-601 & 56.45 & 12.21 & 0.44 & 4.87 & 3.41 & 0.82 & 2.42 & 1.3 & 0.03 & 0.09 & 17.95 \\
\hline 401.4 & $\mathrm{III}\left(3^{\mathrm{rd}} \mathrm{M}\right)$ & S 6 & B 12 & SR & HSBY-598 & 85.13 & 4.79 & 0.17 & 1.65 & 1.52 & 0.56 & 1.63 & 0.28 & 0.07 & 0.04 & 3.81 \\
\hline 399.8 & $\mathrm{III}\left(3^{\mathrm{rd}} \mathrm{M}\right)$ & S 6 & B 12 & SR & HSBY-596 & 91.46 & 2.08 & 0.11 & 1.77 & 0.61 & 0.25 & 1.3 & 0.09 & 0.11 & 0.03 & 2.05 \\
\hline 377.4 & $\| I I\left(3^{\text {rd }} M\right)$ & S 6 & B 12 & BS & HSBY-576 & 53.69 & 12.69 & 0.48 & 5.91 & 4.29 & 1.48 & 2 & 0.62 & 0.03 & 0.18 & 18.63 \\
\hline
\end{tabular}




\begin{tabular}{|c|c|c|c|c|c|c|c|c|c|c|c|c|c|c|c|c|}
\hline 376.6 & $\mathrm{III}\left(3^{\mathrm{rd}} \mathrm{M}\right)$ & S 6 & B 12 & BS & HSBY-575 & 56.1 & 11.35 & 0.44 & 5.17 & 4.09 & 1.36 & 2.93 & 0.61 & 0.04 & 0.13 & 17.8 \\
\hline 376.1 & $\mathrm{III}\left(3^{\mathrm{rd}} \mathrm{M}\right)$ & S 6 & B 12 & $\mathrm{BS}$ & HSBY-574 & 61.84 & 11.61 & 0.26 & 4.97 & 4.89 & 2.49 & 2.48 & 0.69 & 0.02 & 0.02 & 10.73 \\
\hline 375.4 & $\mathrm{III}\left(3^{\mathrm{rd}} \mathrm{M}\right)$ & S 6 & B 12 & BS & HSBY-573 & 67.07 & 8.07 & 0.18 & 6.3 & 4.46 & 0.74 & 1.73 & 0.69 & 0.02 & 0.15 & 10.57 \\
\hline 349.6 & $\mathrm{III}\left(3^{\mathrm{rd}} \mathrm{M}\right)$ & S 6 & B 11 & DL & HSBY-559 & 44.85 & 7.03 & 8.9 & 2.61 & 2.17 & 7.23 & 1.6 & 0.36 & 0.03 & 0.07 & 25.16 \\
\hline 331.5 & $\|\left(2^{\text {nd }} M\right)$ & S 5 & B 10 & BS & HSBY-547 & 70.04 & 10.07 & 0.38 & 4 & 3.13 & 1.61 & 2.19 & 1.13 & 0.02 & 0.22 & 7.21 \\
\hline 299.2 & $\|\left(2^{\text {nd }} M\right)$ & S 5 & B 10 & $\mathrm{BS}$ & HSBY-513 & 46.08 & 13.04 & 0.25 & 6.57 & 3.62 & 1.67 & 1.69 & 1.06 & 0.05 & 0.1 & 25.88 \\
\hline 216.2 & $\|\left(2^{\text {nd }} M\right)$ & S 4 & B 8 & SR & HSBY-456 & 95.98 & 0.19 & 0.53 & 0.71 & 0 & 0.35 & 0.18 & 0.06 & 0.08 & 0.01 & 1.82 \\
\hline 210.1 & $\|\left(2^{\text {nd }} M\right)$ & S 4 & B 8 & SR & HSBY-446 & 96.6 & 0.26 & 0.15 & 1.01 & 0.01 & 0.14 & 0.13 & 0.06 & 0.1 & 0.02 & 1.48 \\
\hline 149.5 & $\mathrm{I}\left(1^{\mathrm{st}} \mathrm{M}\right)$ & S 3 & B 6 & $\mathrm{BS}$ & HSBY-403 & 54.1 & 8.53 & 0.74 & 6.61 & 4.32 & 0.22 & 3.23 & 0.13 & 0.05 & 0.15 & 21.91 \\
\hline 145.2 & $\mathrm{I}\left(1^{\mathrm{st}} \mathrm{M}\right)$ & S 3 & B 6 & BS & HSBY-401 & 55.4 & 12.5 & 0.22 & 1.73 & 3.77 & 3.02 & 1.52 & 0.15 & 0.03 & 0.13 & 21.55 \\
\hline 134.3 & $\mathrm{I}\left(1^{\mathrm{st}} \mathrm{M}\right)$ & S 3 & B 6 & BS & HSBY-393 & 50.84 & 9.8 & 3.99 & 6.72 & 2.83 & 4.32 & 0.17 & 0.1 & 0.04 & 0.37 & 20.82 \\
\hline $\operatorname{Deepth}(\mathrm{m})$ & Member & Series & Bed & Lithology & No. & $\mathrm{SiO}_{2}$ & $\mathrm{Al}_{2} \mathrm{O}_{3}$ & $\mathrm{CaO}$ & $\mathrm{Fe}_{2} \mathrm{O}_{3}$ & $\mathrm{~K}_{2} \mathrm{O}$ & $\mathrm{MgO}$ & $\mathrm{Na}_{2} \mathrm{O}$ & $\mathrm{TiO}_{2}$ & $\mathrm{MnO}$ & $\mathrm{P}_{2} \mathrm{O}_{5}$ & LOI \\
\hline 133.1 & $\mathrm{I}\left(1^{\mathrm{st}} \mathrm{M}\right)$ & S 3 & B 6 & BS & HSBY-392 & 56.41 & 4.51 & 3.98 & 6.93 & 2.48 & 2.65 & 0.76 & 0.09 & 0.06 & 0.37 & 21.75 \\
\hline
\end{tabular}




\begin{tabular}{|c|c|c|c|c|c|c|c|c|c|c|c|c|c|c|c|c|}
\hline 127.8 & $\mathrm{I}\left(1^{\mathrm{st}} \mathrm{M}\right)$ & S 3 & B 6 & $\mathrm{BS}$ & HSBY-389 & 52.13 & 10.44 & 1.58 & 8.23 & 3.15 & 2.01 & 0.34 & 0.1 & 0.03 & 0.45 & 21.55 \\
\hline 126.9 & $\mathrm{I}\left(1^{\mathrm{st}} \mathrm{M}\right)$ & S 3 & B 6 & BS & HSBY-388 & 57.34 & 11 & 0.33 & 5.73 & 3.27 & 1.92 & 0.16 & 0.12 & 0.04 & 0.31 & 19.77 \\
\hline 125.6 & $\mathrm{I}\left(1^{\mathrm{st}} \mathrm{M}\right)$ & S 3 & B 6 & BS & HSBY-387 & 47.05 & 10.98 & 0.84 & 3.21 & 3.19 & 2.48 & 0.22 & 0.12 & 0.02 & 0.2 & 31.69 \\
\hline 124.3 & $\mathrm{I}\left(\mathrm{1}^{\mathrm{st}} \mathrm{M}\right)$ & S 3 & В 6 & BS & HSBY-386 & 57.35 & 11.07 & 0.18 & 6.1 & 3.24 & 1.81 & 0.11 & 0.12 & 0.04 & 0.15 & 19.84 \\
\hline 122.5 & $\mathrm{I}\left(1^{\mathrm{st}} \mathrm{M}\right)$ & S 3 & B 6 & BS & HSBY-385 & 64.11 & 8.53 & 0.35 & 4.56 & 1.03 & 1.32 & 0.21 & 0.09 & 0.03 & 0.25 & 19.53 \\
\hline 120.6 & $\mathrm{I}\left(1^{\mathrm{st}} \mathrm{M}\right)$ & S 3 & B 6 & BS & HSBY-384 & 42.83 & 8.54 & 12.17 & 6.44 & 2.57 & 3.28 & 0.21 & 0.09 & 0.07 & 0.41 & 23.4 \\
\hline 119.5 & $\mathrm{I}\left(1^{\mathrm{st}} \mathrm{M}\right)$ & S 3 & B 6 & BS & HSBY-383 & 50.97 & 8.87 & 6.42 & 6.54 & 2.68 & 4.76 & 0.36 & 0.09 & 0.04 & 0.4 & 18.88 \\
\hline 118.2 & $\mathrm{I}\left(1^{\mathrm{st}} \mathrm{M}\right)$ & S 3 & B 6 & BS & HSBY-382 & 44.68 & 9.19 & 7.91 & 7.78 & 2.76 & 6.37 & 0.12 & 0.12 & 0.05 & 0.48 & 20.55 \\
\hline 117 & $\mathrm{I}\left(\mathrm{1}^{\mathrm{st}} \mathrm{M}\right)$ & S 3 & B 6 & BS & HSBY-381 & 53.69 & 8.32 & 5.81 & 6.56 & 2.55 & 4.56 & 0.27 & 0.09 & 0.04 & 0.41 & 17.71 \\
\hline 115.1 & $\mathrm{I}\left(1^{\mathrm{st}} \mathrm{M}\right)$ & S 3 & B 6 & BS & HSBY-380 & 51.42 & 9.21 & 5.94 & 7.01 & 2.76 & 4.05 & 0.14 & 0.09 & 0.05 & 0.41 & 18.92 \\
\hline 112.4 & $\mathrm{I}\left(1^{\mathrm{st}} \mathrm{M}\right)$ & S 3 & B 6 & BS & HSBY-379 & 53.71 & 7.87 & 6.4 & 5.96 & 2.37 & 4.01 & 0.13 & 0.08 & 0.03 & 0.34 & 19.11 \\
\hline 107.5 & $\mathrm{I}\left(1^{\mathrm{st}} \mathrm{M}\right)$ & S 3 & B 6 & BS & HSBY-375 & 49.15 & 14.51 & 1.13 & 1.89 & 4.22 & 2.29 & 0.58 & 0.18 & 0.04 & 0.5 & 25.51 \\
\hline
\end{tabular}




\begin{tabular}{|c|c|c|c|c|c|c|c|c|c|c|c|c|c|c|c|c|}
\hline 103.7 & $\mathrm{I}\left(1^{\mathrm{st}} \mathrm{M}\right)$ & S 3 & B 6 & BS & HSBY-372 & 50.19 & 11.68 & 3.87 & 7.93 & 3.76 & 3.27 & 0.61 & 0.12 & 0.02 & 0.54 & 18.01 \\
\hline 102.4 & $\mathrm{I}\left(1^{\mathrm{st}} \mathrm{M}\right)$ & S 3 & B 6 & DL & HSBY-371 & 25.19 & 3.33 & 18.56 & 2.35 & 0.99 & 14.07 & 0.18 & 0.03 & 0.03 & 0.29 & 34.98 \\
\hline 101.3 & $\mathrm{I}\left(1^{\mathrm{st}} \mathrm{M}\right)$ & S 3 & B 6 & BS & HSBY-370 & 67.31 & 6.62 & 0.25 & 1.09 & 2.08 & 1.28 & 1.67 & 0.04 & 0.06 & 0.04 & 19.56 \\
\hline 51.1 & $\mathrm{I}\left(1^{\mathrm{st}} \mathrm{M}\right)$ & $\mathrm{S} 2$ & B 4 & BS & HSBY-324 & 62.8 & 15.06 & 1.31 & 3.18 & 4.69 & 1.78 & 1.73 & 0.07 & 0.03 & 0.16 & 9.19 \\
\hline 48.6 & $\mathrm{I}\left(1^{\mathrm{st}} \mathrm{M}\right)$ & $\mathrm{S} 2$ & B 4 & BS & HSBY-318 & 68.55 & 14.54 & 0.6 & 1.27 & 4.65 & 1.65 & 1.52 & 0.07 & 0.01 & 0.03 & 7.11 \\
\hline 23.4 & $\mathrm{I}\left(1^{\mathrm{st}} \mathrm{M}\right)$ & $\mathrm{S} 2$ & B 3 & SR & HSBY-307 & 80.86 & 5.54 & 0.45 & 6.15 & 1.72 & 0.64 & 1.6 & 0.03 & 0.03 & 0.11 & 2.67 \\
\hline \multicolumn{6}{|c|}{ Average value of anomalous Se-enrichment $\mathrm{SR}(\mathrm{n}=10)$} & 90.27 & 2.6 & 0.21 & 1.88 & 0.79 & 0.35 & 0.95 & 0.13 & 0.08 & 0.03 & 2.71 \\
\hline \multicolumn{6}{|c|}{ Average value of anomalous Se-enrichment BS $(n=27)$} & 54.52 & 10.15 & 3.04 & 5.2 & 3.26 & 2.9 & 1.06 & 0.29 & 0.04 & 0.26 & 19.29 \\
\hline \multicolumn{6}{|c|}{ Average value of anomalous Se-enrichment DL $(n=3)$} & 29.29 & 4.26 & 17.09 & 1.47 & 1.28 & 11.72 & 1.88 & 0.21 & 0.03 & 0.26 & 32.5 \\
\hline \multicolumn{6}{|c|}{ Franciscan SR (Yomatou et al 1987) } & 93.10 & 1.31 & 0.11 & 2.63 & 0.35 & 0.28 & 0.11 & 0.09 & 0.53 & 0.03 & - \\
\hline
\end{tabular}




\section{Table 6 Trace elements of anomalous Se-enrichment samples of the LFm from Ziyang county, southern Shaanxi Province (China) (unit: ppm)}

Abbreviations : D.=Deepth, $\mathrm{m}=$ meter, s.=Sereies, SR=Siliceous rock, DL=Dolomistic Limestone, BS=Black Shale, No.=Sample number.

\begin{tabular}{|c|c|c|c|c|c|c|c|c|c|c|c|c|c|c|c|c|c|c|c|c|c|c|c|c|c|c|c|c|c|c|c|c|c|c|}
\hline D. $(\mathbf{m})$ & Iember & s. & ed & Lithology & o. & e & As & d & $\mathbf{0}$ & Tl & Cs & Ga & In & b & $\mathbf{U}$ & Bi & Mo & $\mathbf{B e}$ & Th & $\mathrm{Cr}$ & $\mathrm{Cu}$ & Li & $\mathbf{N i}$ & $\mathbf{P}$ & $\mathbf{P b}$ & $\mathbf{S}$ & Sc & $\mathrm{Sr}$ & V & $\mathbf{Z n}$ & Ba & Se & & $\mathbf{C o} / \mathbf{Z n}$ \\
\hline 474.1 & & & & & & 81 & 26 & & & 7.81 & & 45 & 6 & 40 & 69 & & 0 & 1.71 & 6 & & 2 & 6 & 620 & 462 & 1 & & 15 & 42 & & 62 & 77 & 52 & 22 & 0019 \\
\hline 459.2 & th $M$ & & & & & 57 & 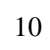 & & 4 & 9 & 2 & ) & 0.02 & 21 & 24 & 37 & 7 & 0.68 & 8 & 7 & 167 & 71 & 104 & 124 & 19 & 78 & 94 & 37 & 86 & 53 & 64 & 4 & 2 & 80 \\
\hline 4 & $\mathrm{IV}\left(4^{\text {th }} \mathrm{M}\right)$ & $S_{7}$ & & SR & 7 & 104 & 33 & 2 & 4 & 54 & 2 & 5 & 0.04 & 55 & 82 & 0.98 & 13 & 2.12 & 5.47 & 8 & 211 & 324 & 472 & 406 & 74 & ) & 64.47 & 37 & 5425 & 1478 & 330 & 227 & 5 & 0.0075 \\
\hline . & M) & S 7 & P 13 & SR & 10 & 53 & 27 & 2 & 2.44 & 6.93 & 773 & 314 & 0.06 & 29 & 43 & 0.63 & 17 & 0.98 & 3.82 & 197 & 58 & 203 & 355 & 223 & 33 & 8011 & 34.82 & 32 & 3886 & 487 & 8082 & 150 & 11 & 0050 \\
\hline 449.4 & (th & 7 & В 13 & SR & 639 & 52 & 8 & 1 & 1.25 & 1.69 & 12 & & 0.03 & 16 & 50 & 0.52 & 7 & 0.54 & 2 & 149 & 73 & 11 & 96 & 01 & 29 & 2293 & 13.97 & 36 & 1895 & 332 & 5815 & 44 & 25 & .0038 \\
\hline 408. & $\left(3^{\text {rd }} \mathrm{M}\right)$ & 6 & $\mathrm{E}$ & D & 6 & 41 & 11 & 13.96 & 0.96 & 1.42 & 4 & 54 & 0.03 & 9 & 62 & 0.36 & 2 & 0.42 & 0.88 & 29 & 129 & 101 & 1171 & 1963 & 14 & 2091 & 12 & 388 & 1018 & 1093 & 3047 & 51 & 70 & 0009 \\
\hline 403. & $\left(\begin{array}{lll}3 & M\end{array}\right)$ & 6 & I & BS & HSB & 303 & 81 & 1.39 & 1.12 & 7.39 & 1.87 & 470 & 0.04 & 43 & 69 & 0.65 & 372 & 2.11 & 5.51 & 190 & 108 & 282 & 210 & 380 & 47 & 6216 & 27.37 & 122 & 4173 & 1131 & 28590 & 21 & 12 & 0.0010 \\
\hline 401. & $\left(\begin{array}{lll}(3 & 101\end{array}\right)$ & 6 & l & SR & & 68 & 31 & 0.42 & 0.79 & 2.19 & 1 & 119 & 0.04 & 31 & 41 & 0.37 & 10 & 1.14 & 2.97 & 113 & 59 & 17 & 92 & 177 & 25 & 2039 & 16.69 & 55 & 2857 & 714 & 6313 & 30 & 14 & .0011 \\
\hline 399.8 & $\| I I\left(3^{\text {rd }} \mathbf{M}\right)$ & 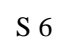 & B 12 & SR & 6 & 51 & 15 & 1 & 12 & 1.46 & 45 & 54 & 0.03 & 12 & 35 & 0.28 & 23 & 0.33 & 1.16 & 91 & 1 & 67 & 72 & 136 & 19 & 1954 & 1 & 0 & 2 & 565 & 2691 & 39 & 30 & 20 \\
\hline 377. & $\left(3^{\mathrm{rd}} \mathrm{M}\right)$ & 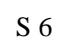 & B 12 & BS & 6 & 80 & 62 & 0 & 11.38 & 3.52 & 9 & 16 & 0.05 & 80 & 30 & 0.56 & 60 & 2.14 & 7 & 92 & 73 & $31=$ & 56 & 782 & 1 & 54670 & 15.3 & 109 & 239 & 686 & 448 & 685 & 4 & 66 \\
\hline 376. & $\left(3^{\text {rd }} \mathrm{M}\right)$ & S 6 & B 12 & BS & 5 & 60 & 53 & 0 & 8 & 3.05 & 3 & 142 & 0.05 & 78 & 21 & 0.92 & 56 & 2.58 & 7.69 & 97 & 63 & 325 & 52 & 548 & 48 & 47 & 14.08 & 122 & 223 & 1636 & 8291 & 801 & 3 & 0.0051 \\
\hline 376. & $\|||\left(3^{\mathrm{rd}} \mathrm{M}\right)$ & 6 & $\mathrm{~F}$ & B & 574 & 89 & 38 & 0.45 & 8.05 & 2.69 & 3.29 & 48 & 0.05 & 84 & 21 & 0.58 & 47 & 3.79 & 3.6 & 107 & 37 & 595 & 52 & 107 & 17 & 48 & 15.19 & 57 & 256 & 915 & 2146 & 551 & 6 & 88 \\
\hline 375. & $\| I I\left(3^{\text {rd }} M\right)$ & 6 & B 12 & B & $\mathrm{H}$ & 68 & 73 & & 12 & 3.8 & 1.44 & 47 & 0.06 & 65 & 17 & 0.71 & 312 & 2.88 & 2.99 & 100 & 76 & 387 & 75 & 672 & 35 & 60780 & 10.92 & 28 & 248 & 866 & 2193 & 893 & 6 & 0.0139 \\
\hline 349.6 & $111(3-10)$ & S 6 & B & DL & 9 & 42 & 72 & 1. & 5.25 & 1.74 & 1.92 & 48 & 0.04 & 42 & 19 & 0.44 & 17 & 1.51 & 4.47 & 90 & 48 & 41 & 91 & 321 & 1 & 23360 & 8.22 & 155 & 1110 & 573 & 2781 & 560 & 4 & 0.0092 \\
\hline 331.5 & $u_{0}$ nd & S 5 & & & & 47 & 3 & 0.52 & 1 & 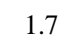 & 2 & 28 & 0 & 52 & 40 & 0.57 & 43 & 1.77 & 3.32 & 97 & 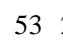 & 277 & 72 & 967 & 13 & & 13.4 & 1 & 4421 & 1200 & 1057 & 748 & 12 & \\
\hline 299.2 & $\left(2^{\text {nd }} M\right)$ & S 5 & B 10 & BS & 3 & 71 & 20 & 3 & 12.52 & 2.75 & 18 & 14 & 0.04 & 62 & 8 & 0.33 & 212 & 2.22 & 4.32 & 100 & 85 & 205 & 58 & 448 & 7 & 59 & 25.89 & 99 & 299 & 531 & 170 & 834 & 2 & 0.0236 \\
\hline 210 & $\|\left(2^{\text {nd }} M\right)$ & S 4 & D & SR & $\Pi$ & 38 & 3 & $J$. & 1.53 & 0.59 & 0 & 8 & 0 & 4 & 6 & 04 & 17 & 0.09 & 0.24 & 26 & 301 & 32 & 24 & 65 & 14 & 00 & 2.68 & 12 & 33 & 17 & 20 & 20 & 4 & 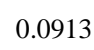 \\
\hline 2 & $\left(2^{\text {nd }} M\right)$ & S 4 & B & SR & 6 & 60 & 4 & 0 & 1.65 & 0.68 & 13 & 8 & 0 & 4 & 5 & 0.03 & 13 & 0.11 & 77 & 44 & 80 & 43 & 30 & 84 & 14 & 0 & 1.17 & 0 & 219 & 31 & 467 & 11 & 7 & - \\
\hline 149. & $\mathrm{I}\left(1^{\mathrm{st}} \mathrm{M}\right)$ & S 3 & B 6 & BS & HSBY-403 & 62 & 41 & 0.85 & 1.4 & 5.09 & 1.4 & 35 & 0.11 & 59 & 29 & 0.6 & 4052 & 2.91 & 2.11 & 209 & 69 & 433 & 31 & 674 & 51 & 31 & 16.29 & 23 & 3938 & 567 & 1025 & 508 & 14 & 0 . \\
\hline 145.2 & $\mathrm{I}\left(1^{\mathrm{st}} \mathrm{M}\right)$ & S 3 & B 6 & BS & HSBY-401 & 87 & 36 & 2.45 & 1.09 & 6.36 & 4.03 & 23 & 0.04 & 66 & 88 & 0.42 & 256 & 2.84 & 4.49 & 136 & 74 & 55 & 44 & 582 & 39 & 11010 & 36.47 & 78 & 6834 & 615 & 1185 & 126 & 20 & 0.0018 \\
\hline
\end{tabular}




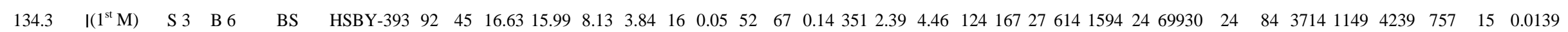

\begin{tabular}{|c|c|c|c|c|c|c|c|c|c|c|c|c|c|c|c|c|c|c|c|c|c|c|c|c|c|c|c|c|c|c|c|c|c|c|}
\hline D. $(\mathbf{m})$ & Member & s. & Bed & Lithology & No.. & Se & As & Cd & Co & Tl & Cs & $\mathbf{G a}$ & In & $\mathbf{R b}$ & $\mathbf{U}$ & $\mathbf{B i}$ & Mo & $\mathbf{B e}$ & Th & $\mathrm{Cr}$ & $\mathbf{C u}$ & Li & $\mathbf{N i}$ & $\mathbf{P}$ & $\mathbf{P b}$ & $\mathbf{S}$ & Sc & $\mathrm{Sr}$ & $\mathbf{v}$ & $\mathbf{Z n}$ & $\mathbf{B a}$ & S/Se & U/Tr & h $\mathrm{Co} / \mathrm{Zn}$ \\
\hline 133.1 & IVI) & 3 & B 6 & BS & HSBY-392 & 90 & 68 & 11.85 & 15.49 & 8.59 & 1.82 & 58 & 0.05 & 17 & 73 & 0.36 & 376 & 2.41 & 0.07 & 124 & 300 & 214 & 4811 & 1635 & 42 & 64370 & 8.34 & 72 & 3412 & 649 & 3658 & 713 & 103 & 80.0239 \\
\hline 127.8 & $\mathrm{I}\left(1^{\mathrm{st}} \mathrm{M}\right.$ & S 3 & B & BS & 89 & 105 & 79 & 5.13 & 13.35 & 8.32 & 13 & 94 & 0.05 & 53 & 65 & 0.37 & 226 & 2.16 & 3.65 & 203 & 381 & 224 & 4861 & 1949 & 46 & 70010 & 24.81 & 59 & 4073 & 525 & 7867 & 664 & 18 & .0254 \\
\hline 126.9 & $\mathrm{I}\left(1^{\mathrm{st}} \mathrm{M}\right.$ & S 3 & B & $\mathrm{E}$ & SBY-388 & 143 & 73 & 3.55 & 6.21 & 5.62 & 62 & 192 & 0.07 & 71 & 82 & 0.43 & 321 & 4.56 & 5.75 & 138 & 174 & 253 & 3211 & 1367 & 53 & 10490 & 27.65 & 92 & 4585 & 470 & 11760 & 73 & 14 & .0132 \\
\hline 125.6 & $\mathrm{I}\left(1^{\mathrm{st}} \mathrm{M}\right.$ & 3 & B & B & SBY-387 & 94 & 40 & 2.64 & 10.2 & 4.89 & 3.91 & 162 & 0.05 & 66 & 105 & 0.49 & 369 & 3.38 & 5.98 & 97 & 92 & 271 & 146 & 864 & 64 & 11850 & 28.78 & 123 & 5500 & 418 & 10820 & 125 & 18 & .0244 \\
\hline 124.3 & $\mathrm{I}\left(1^{\mathrm{st}} \mathrm{M}\right)$ & S 3 & B & BS & -386 & 154 & 71 & .9 & 5.55 & 6.64 & 3.45 & 168 & 0.05 & 65 & 68 & 0.43 & 562 & 4.16 & 5 & 214 & 231 & 241 & 192 & 639 & 45 & 8164 & 25.14 & 85 & 4358 & 472 & 11200 & 53 & 14 & .0118 \\
\hline 122.5 & I & S 3 & B & BS & BY-385 & 152 & 110 & 2.63 & 5.52 & 4.12 & 2.37 & 27 & 0.04 & 24 & 60 & 0.18 & 200 & 2.06 & 3.33 & 80 & 362 & 182 & 2191 & 1102 & 8 & 4829 & 21.1 & 44 & 3356 & 462 & 2528 & 32 & 18 & 0.0120 \\
\hline 120.6 & $\mathrm{I}\left(1^{\mathrm{st}} \mathrm{M}\right.$ & S 3 & B & $B$ & HSBY-384 & 114 & 66 & 55.06 & 19.86 & 8.06 & 3.06 & 102 & 0.05 & 52 & 42 & 0.32 & 352 & 3.06 & 4.26 & 182 & 343 & 228 & 8631 & 1790 & 39 & 2937 & 19.5 & 184 & 3486 & 1918 & 7020 & 26 & 10 & 0.0104 \\
\hline 119.5 & $\mathrm{I}\left(1^{\mathrm{st}} \mathrm{M}\right)$ & $\mathrm{S} 3$ & В 6 & BS & HSBY-383 & 69 & 76 & 11.19 & 14.59 & 10.27 & 2.73 & 15 & 0.05 & 49 & 60 & 0.19 & 177 & 1.95 & 2.79 & 87 & 296 & 214 & 4241 & 1745 & 2 & 52350 & 20.09 & 117 & 3257 & 395 & 421 & 755 & 21 & 0.0369 \\
\hline 118.2 & $\mathrm{I}\left(1^{\mathrm{st}} \mathrm{M}\right)$ & S 3 & B 6 & BS & HSBY-382 & 77 & 77 & 10.94 & 17.42 & 9.62 & 3.11 & 16 & 0.05 & 54 & 62 & 0.25 & 306 & 2.29 & 3.28 & 197 & 328 & 224 & 4202 & 2116 & 17 & 67670 & 22.1 & 133 & 3530 & 526 & 1222 & 875 & 19 & 0.0331 \\
\hline 117 & $\mathrm{I}\left(1^{\mathrm{st}} \mathrm{M}\right)$ & S 3 & B 6 & B & HSBY-381 & 67 & 80 & 25.29 & 14.16 & 8.19 & 2.69 & 36 & 0.04 & 44 & 51 & 0.27 & 208 & 1.77 & 2.81 & 173 & 399 & 193 & 3891 & 1786 & 23 & 48200 & 19 & 106 & 2994 & 424 & 2774 & 720 & 18 & 0.0334 \\
\hline 115.1 & $\left(\begin{array}{ll}1 & 101\end{array}\right)$ & S 3 & B 6 & 1 & HSBY-380 & 67 & 100 & 14.08 & 16.97 & 9.68 & 3.25 & 23 & 0.05 & 58 & 60 & 0.31 & 257 & 2.61 & 1.12 & 294 & 445 & 223 & 3861 & 1785 & 15 & 52950 & 18.9 & 101 & 3593 & 309 & 1071 & 789 & 54 & 0.0550 \\
\hline 112 & $\mathrm{I}\left(1^{\mathrm{st}} \mathrm{M}\right.$ & S 3 & B & BS & 79 & 70 & 87 & 2 & 13.94 & 3 & 2 & 97 & 0.06 & 49 & 63 & 0. & 310 & 2.4 & 3.99 & 207 & 327 & 204 & 4321 & 1470 & 39 & 28 & 18.42 & 106 & 3194 & 440 & 5926 & 400 & 16 & 17 \\
\hline 107. & $\mathrm{I}\left(1^{\mathrm{st}} \mathrm{M}\right)$ & S 3 & B & $\mathrm{E}$ & 75 & 102 & 20 & 0.42 & 0.91 & 6.51 & 29 & 173 & 0.02 & 92 & 29 & 0.65 & 99 & 5.07 & 4.88 & 123 & 22 & 22 & 252 & 2182 & 67 & 2 & 23 & 308 & 3967 & 43 & 9787 & 251 & 6 & 14 \\
\hline 103.7 & $\mathrm{I}\left(1^{\mathrm{st}} \mathrm{M}\right)$ & S 3 & B 6 & $\mathrm{E}$ & HSBY-372 & 86 & 62 & 3.17 & 18.23 & 8.53 & 4.71 & 148 & 0.05 & 74 & 53 & 0.5 & 86 & 3.86 & 5.67 & 119 & 145 & 324 & 4012 & 2373 & 50 & 63630 & 27.32 & 82 & 2846 & 497 & 10410 & 741 & 9 & 0.0367 \\
\hline 102.4 & $\mathrm{I}\left(1^{\mathrm{st}} \mathrm{M}\right)$ & S 3 & B 6 & DL & HSBY-371 & 85 & 15 & 8.4 & 5.47 & 3.04 & 1.36 & 29 & 0.03 & 20 & 35 & 0.12 & 28 & 1.47 & 2.01 & 53 & 78 & 162 & 2451 & 1262 & 12 & 20130 & 6.3 & 210 & 1860 & 315 & 2107 & 237 & 17 & 0.0174 \\
\hline 101.3 & $\mathrm{I}\left(1^{\mathrm{st}} \mathrm{M}\right)$ & S 3 & B 6 & $\mathrm{E}$ & HSBY-370 & 46 & 14 & 0.94 & 1.56 & 3.71 & 3.57 & 91 & 0.06 & 49 & 48 & 0.46 & 94 & 5 & 3.84 & 306 & 234 & 27 & 107 & 194 & 54 & 8244 & 29.39 & 62 & 9147 & 622 & 5843 & 178 & 12 & 0.0025 \\
\hline 51.1 & $\mathrm{I}\left(1^{\mathrm{st}} \mathrm{M}\right)$ & S 2 & B 4 & B & HSBY-324 & 58 & 31 & 1.8 & 5.8 & 2.54 & 6.1 & 32 & 0.07 & 151 & 12 & 0.81 & 104 & 4.79 & 8.02 & 71 & 54 & 34 & 43 & 719 & 13 & 31480 & 20.3 & 75 & 1569 & 610 & 928 & 542 & 2 & 0.0095 \\
\hline 48.6 & $\mathrm{I}\left(1^{\mathrm{st}} \mathrm{M}\right)$ & S 2 & B 4 & BS & HSBY-318 & 52 & 14 & 0.41 & 1.33 & 2.03 & 6.35 & 121 & 0.05 & 165 & 8 & 1.39 & 57 & 4.31 & 10.94 & 50 & 16 & 34 & 13 & 112 & 42 & 10430 & 17.98 & 68 & 1099 & 508 & 5648 & 201 & 1 & 0.0026 \\
\hline 23.4 & $\mathrm{I}\left(1^{\mathrm{st}} \mathrm{M}\right)$ & $\mathrm{S} 2$ & B 3 & SR & HSBY-307 & 42 & 207 & 2.03 & 7.4 & 0.9 & 2.22 & 61 & 0.1 & 48 & 12 & 0.46 & 332 & 1.52 & 3.61 & 94 & 167 & 751 & 105 & 478 & 42 & 705 & 4.9 & 55 & 1723 & 737 & 3582 & 17 & 3 & 0.0100 \\
\hline
\end{tabular}


Table 7 Race earth elements of anomalous Se-enrichment samples of the LFm from Ziyang county, southern Shaanxi Province (China) (unit: ppm)

Abbreviations : SR=Siliceous rock. DL=Dolomistic Limestone, BS=Black Shale, L/H=LREE/HREE,

\begin{tabular}{|c|c|c|c|c|c|c|c|c|c|c|c|c|c|c|c|c|c|c|c|c|c|c|c|c|c|c|}
\hline $\operatorname{Deepth}(\mathbf{m})$ & Member & Series & Bed & thology & o. & $Y$ & La & Ce & Pr & Nd & m & $\mathbf{u}$ & id & & $y$ & Но & $\mathbf{r}$ & m & $\mathbf{Y b}$ & Lu & $\sum$ REE & $\mathrm{L} / \mathrm{H}$ & $\mathbf{u}^{* / \mathbf{E u}} \mathbf{u}^{*}$ & e/Ce* & $\mathbf{Y} / \mathbf{H}$ & $\mathrm{a} / \mathrm{Ce})$ \\
\hline 474.1 & $\operatorname{IV}\left(4^{\text {th }} M\right)$ & 7 & & & 2 & 0 & 7 & 9 & & & & & & & 5 & & 57 & & 7 & 33 & 44 & 3.96 & 9 & 0.69 & 54 & 41 \\
\hline 459.2 & $4^{\text {th }}$ & S 7 & D 12 & SR & 8 & 2 & 7.33 & 4 & 1.68 & & 3.13 & 2.15 & 1.36 & & 9 & 4 & 1.54 & 0.41 & 5 & 57 & 5 & & 4.84 & 0 & 30 & 44 \\
\hline 458.1 & 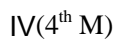 & & & & 7 & & 2.57 & & & & & 36 & 0.66 & & 0.71 & 7 & 0.61 & 5 & 2 & 19 & 2 & 3.01 & 2.51 & 3 & 5 & 99 \\
\hline 450.3 & ha & $\mathrm{S}_{7}$ & & SR & 0 & 59 & 5 & 2 & 4.66 & 0 & 1 & 29 & 4.29 & .02 & 4.98 & 9 & 4.70 & 0 & 1 & 64 & 33 & 2 & 3.25 & 70 & 40 & 35 \\
\hline 404 & $\mathrm{IV}\left(4^{\text {th }} \mathrm{M}\right)$ & S 7 & B 13 & & 9 & 3 & 2 & 2 & 8 & 6 & 5 & 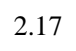 & 2.40 & & 2.74 & 8 & 5 & 6 & 0 & 2 & 7 & 3.85 & 3.53 & 4 & 4 & 1.32 \\
\hline 408.2 & $\mathrm{III}\left(3^{\text {rd }} \mathrm{M}\right)$ & 56 & 1 & & BY-606 & 74 & 51 & 37 & 1.22 & 62 & 42 & 08 & 2.55 & & 87 & 1.01 & 12 & 0.53 & 60 & 0.64 & 35.53 & 1.71 & .56 & 0.66 & 31 & 1.56 \\
\hline 403.4 & $\mathrm{III}\left(3^{\text {rd }} \mathrm{M}\right)$ & S 6 & В 12 & & BYY-601 & .58 & .86 & 50.05 & 8.31 & 30.21 & 11.97 & 6.91 & 5.41 & 3 & .72 & 1.49 & 36 & 0.69 & 3.04 & 0.89 & 168.95 & 7.19 & 1.00 & 0.63 & 19 & 1.70 \\
\hline 401.4 & $\mathrm{III}\left(3^{\text {rd }} \mathrm{M}\right)$ & 6 & 10 & & BBY-598 & 44.68 & 93 & 28.63 & 4.18 & 13.95 & 4.41 & .04 & 3.50 & 75 & 3.94 & 1.40 & 68 & 0.87 & 4.72 & 1.21 & 90.21 & 3.50 & .57 & .78 & 85 & 1.23 \\
\hline 399.8 & (I) & S 6 & В 12 & & 96 & 38.41 & 7.32 & 11.04 & 2.02 & 11 & 3.43 & .41 & 3.62 & 72 & 3.56 & 1.22 & .94 & 0.65 & 3.35 & 0.82 & 49.88 & 1.96 & .07 & 0.66 & 1.60 & 1.38 \\
\hline 377.4 & $\|\left(3^{\text {rd }} M\right)$ & $\mathrm{c} 6$ & B 12 & & & 2 & 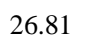 & 4 & 6 & 2 & & & & & 2.73 & & 1.63 & & & 1 & & & & 4 & 30.19 & 11 \\
\hline 376.6 & $\mathrm{III}\left(3^{\text {rd }} \mathrm{M}\right)$ & $\mathrm{C} G$ & В 12 & & 5 & 10 & 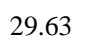 & 4 & 6 & 2 & & 17 & 2.73 & & 100 & & & 0.26 & 1.24 & 4 & & & 2.76 & 0.81 & & 1.26 \\
\hline 6 & $\operatorname{III}\left(3^{\text {rd }} \mathbf{M}\right)$ & S 6 & B 12 & BS & 4 & 7.81 & 12.77 & 29.6 & 3.58 & 11.14 & 245 & 0.73 & 1 & 0.28 & 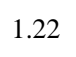 & 0.36 & 088 & 0.20 & 0 & 23 & 66.06 & 10. & 1.84 & 1.01 & 2 & 90 \\
\hline 375.4 & $\mathrm{III}\left(3^{\text {rd }} \mathrm{M}\right)$ & 6 & B & BS & BY-573 & 4.35 & 25 & 26.13 & 1.56 & 460 & 1.53 & 63 & 0.9 & 15 & 0.65 & 0.19 & .44 & 0.10 & 0.49 & 0.11 & 43.85 & 13.40 & 9 & 1.93 & 22 & 0.50 \\
\hline 32 & $\mathrm{III}\left(3^{\text {rd }} \mathrm{M}\right)$ & S 6 & B & 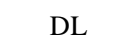 & & 17 & 2 & 30 & 3.92 & 12.39 & 3.30 & 1.16 & 2. & & 1.94 & 0.58 & 1.28 & 0.25 & 14 & 0.26 & 78 & 8 & e & 0.80 & 41 & 1.33 \\
\hline 331.5 & $\|\left(2^{\text {nd }} M\right)$ & & B 10 & & & 28.42 & 34.36 & 48.82 & 10.59 & 45.42 & 8.29 & 1.98 & 6.0 & 32 & 2.80 & 0.77 & 1.6 & 0.31 & 1.34 & 0.28 & & 10.67 & 1. & 0.58 & 1 & 47 \\
\hline (2) & 111 & & (4) & & & 31.79 & 38.31 & 61.70 & 10.86 & 40.04 & 6.97 & 1.49 & 5.46 & & 3.00 & 1.00 & 2.4 & 0.31 & 2.32 & 0.56 & 176.51 & 9. & 1. & 69 & & 1.29 \\
\hline 216.2 & urand & 34 & D 0 & & 6 & 6 & 1.46 & 2.13 & 0 & 1.45 & 0.41 & 0.12 & 0 & 0.07 & 0.40 & 0.11 & 0.72 & 0.07 & 0.53 & 0.08 & 8.12 & 2.05 & 1.30 & .73 & 0 & 1.43 \\
\hline 210.1 & $\|\left(2^{\text {nd }} M\right)$ & 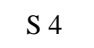 & $D 0$ & & HSBY-446 & 7.05 & (2) & 01 & 0.00 & 2.10 & 0.12 & 0.17 & 0.13 & 0.10 & 0.01 & 0.16 & . & 0.07 & 0.45 & 0.07 & 13.21 & 3.01 & 1.23 & 0.83 & 44.55 & 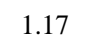 \\
\hline (1) & $\mathrm{I}\left(1^{\mathrm{st}} \mathrm{M}\right)$ & S 3 & B 6 & & 3 & 6.20 & 0 & 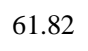 & 4.53 & 70 & 3.55 & 0.76 & 2. & 0.29 & 1 & 3 & 0.94 & 5 & 0.76 & 0.11 & 0 & 2 & 3 & 1.60 & 6 & 9 \\
\hline 145.2 & $\mathrm{I}\left(1^{\mathrm{st}} \mathrm{M}\right)$ & S & B 6 & BS & HSBY-401 & 62.01 & 57.65 & 77.64 & 12.59 & 59.72 & 10.74 & 1.99 & 10.07 & 34 & 8.61 & 1.96 & 6.15 & 0.82 & 5.07 & 0.73 & 255.07 & 6.34 & 0.95 & 0.66 & 31.68 & 1.55 \\
\hline
\end{tabular}




\begin{tabular}{|c|c|c|c|c|c|c|c|c|c|c|c|c|c|c|c|c|c|c|c|c|c|c|c|c|c|c|}
\hline 134.3 & $\mathrm{I}\left(1^{\mathrm{st}} \mathrm{M}\right)$ & S 3 & В 6 & BS & HSBY-393 & 58.18 & 25.39 & 51.11 & 7.85 & 38.95 & 8.92 & 2.01 & 9.38 & 26 & 7.88 & 1.70 & 5.31 & 0.69 & 4.15 & 0.60 & 165.19 & 4.34 & 1.09 & 0.83 & 34.30 & .04 \\
\hline Deepth(m) & Member & Series & Bed & Lithology & No. & $\mathbf{Y}$ & $\mathbf{L a}$ & $\mathrm{Ce}$ & Pr & Nd & $\mathrm{Sm}$ & $\mathbf{E u}$ & Gd & $\mathbf{T b}$ & y & Ho & Er & m & $\mathbf{Y b}$ & Lu & $\sum \mathbf{R E E}$ & $L / H$ & $\mathbf{E} \mathbf{u}^{* / \mathbf{E}} \mathbf{u}^{*}$ & $/ \mathrm{Ce}^{*}$ & Y/Ho & $\mathrm{Ce}$ \\
\hline 133.1 & $\mathrm{I}\left(1^{\mathrm{st}} \mathrm{M}\right)$ & S 3 & B 6 & BS & HSBY-392 & 46.33 & 35.91 & 54.06 & 8.13 & 39.06 & 8.56 & 05 & 8.51 & 11 & 6.91 & 1.50 & 4.59 & 0.60 & 3.63 & 0.54 & 5.17 & 5.39 & 1.19 & 0.73 & 30.94 & 1.38 \\
\hline 127.8 & $\mathrm{I}\left(1^{\mathrm{st}} \mathrm{M}\right)$ & S 3 & B 6 & BS & HSBY-389 & 56.78 & 39.90 & 56.53 & 8.20 & 40.06 & 10.20 & 3.07 & 9.18 & 1.22 & 7.68 & 1.69 & 5.16 & 0.68 & 4.04 & 0.61 & 188.22 & 5.22 & 1.58 & 0.72 & 33.66 & 1.47 \\
\hline 126.9 & $\mathrm{I}\left(1^{\mathrm{st}} \mathrm{M}\right)$ & S 3 & B 6 & BS & HSBY-388 & 70.66 & 58.97 & 80.84 & 11.54 & 54.41 & 13.76 & 4.27 & 10.91 & 1.50 & 10.01 & 2.27 & 6.91 & 0.91 & 5.42 & 0.84 & 262.57 & 5.77 & 1.73 & 0.71 & 31.08 & 1.52 \\
\hline 125.6 & $\mathrm{I}\left(1^{\mathrm{st}} \mathrm{M}\right)$ & S 3 & B 6 & $\mathrm{BS}$ & HSBY-387 & 69.39 & 64.48 & 85.25 & 12.35 & 56.54 & 12.56 & 3.73 & 9.93 & 1.35 & 9.05 & 2.13 & 6.80 & 0.90 & 5.41 & 0.78 & 271.26 & 6.46 & 1.66 & 0.69 & 32.64 & 1.58 \\
\hline 124.3 & $\mathrm{I}\left(1^{\mathrm{st}} \mathrm{M}\right)$ & S 3 & B 6 & BS & HSBY-386 & 49.88 & 49.32 & 68.23 & 9.62 & 43.23 & 10.82 & 3.53 & 7.98 & 1.09 & 7.18 & 1.60 & 5.17 & 0.69 & 4.23 & 0.64 & 213.33 & 6.47 & 1.88 & 0.72 & 31.20 & 1.51 \\
\hline 122.5 & $\mathrm{I}\left(1^{\mathrm{st}} \mathrm{M}\right)$ & S 3 & B 6 & BS & HSBY-385 & 38.59 & 35.00 & 50.53 & 7.59 & 36.39 & 7.36 & 1.71 & 7.02 & 0.96 & 6.10 & 1.36 & 4.13 & 0.56 & 3.47 & 0.50 & 162.69 & 5.75 & 1.18 & 0.71 & 28.37 & 1.44 \\
\hline 120.6 & $\mathrm{I}\left(\mathrm{1}^{\mathrm{st}} \mathrm{M}\right)$ & S 3 & B 6 & BS & HSBY-384 & 65.78 & 43.21 & 59.37 & 8.92 & 42.74 & 11.21 & 3.49 & 10.38 & 1.35 & 8.38 & 1.83 & 5.60 & 0.72 & 4.33 & 0.65 & 202.18 & 5.08 & 1.61 & 0.70 & 35.93 & 1.52 \\
\hline 119.5 & $\mathrm{I}\left(1^{\mathrm{st}} \mathrm{M}\right)$ & S 3 & B 6 & BS & HSBY-383 & 54.21 & 26.90 & 43.32 & 7.06 & 34.86 & 7.67 & 1.77 & 8.04 & 1.11 & 6.53 & 1.41 & 4.36 & 0.57 & 3.52 & 0.51 & 147.64 & 4.66 & 1.12 & 0.72 & 38.35 & 1.29 \\
\hline 118.2 & $\mathrm{I}\left(1^{\mathrm{st}} \mathrm{M}\right)$ & S 3 & B & BS & SBY-382 & 65.92 & 25.74 & 47.88 & 7.39 & 38.04 & 8.39 & 1.95 & 8.85 & 1.20 & 7.51 & 1.63 & 5.03 & 0.65 & 4.00 & 0.57 & 158.82 & 4.40 & 1.12 & 0.80 & 40.41 & 1.12 \\
\hline 117 & $\mathrm{I}\left(1^{\mathrm{st}} \mathrm{M}\right)$ & S 3 & B 6 & $\mathrm{BS}$ & HSBY-381 & 50.23 & 25.06 & 39.71 & 6.18 & 30.95 & 7.59 & 2.08 & 7.67 & 1.02 & 6.32 & 1.37 & 4.24 & 0.56 & 3.30 & 0.49 & 136.51 & 4.47 & 1.35 & 0.74 & 36.69 & 1.32 \\
\hline 115.1 & $\mathrm{I}\left(1^{\mathrm{st}} \mathrm{M}\right)$ & S 3 & B 6 & BS & HSBY-380 & 52.92 & 32.98 & 50.72 & 7.78 & 38.06 & 8.31 & 1.99 & 8.34 & 1.11 & 6.98 & 1.53 & 4.65 & 0.61 & 3.84 & 0.54 & 167.44 & 5.07 & 1.19 & 0.73 & 34.51 & 1.35 \\
\hline 112.4 & $\mathrm{I}\left(1^{\mathrm{st}} \mathrm{M}\right)$ & S 3 & B 6 & BS & HSBY-379 & 46.32 & 39.42 & 54.76 & 7.94 & 37.74 & 9.67 & 2.89 & 8.55 & 1.15 & 7.04 & 1.54 & 4.75 & 0.61 & 3.72 & 0.54 & 180.30 & 5.46 & 1.58 & 0.71 & 30.01 & 1.50 \\
\hline 107.5 & $\mathrm{I}\left(1^{\mathrm{st}} \mathrm{M}\right)$ & S 3 & B 6 & BS & HSBY-375 & 38.57 & 71.30 & 112.04 & 12.77 & 52.17 & 10.54 & 3.05 & 5.97 & 0.65 & 4.11 & 1.00 & 3.74 & 0.54 & 3.60 & 0.61 & 282.11 & 12.95 & 1.85 & 0.85 & 38.41 & 1.33 \\
\hline 103.7 & $\mathrm{I}\left(1^{\mathrm{st}} \mathrm{M}\right)$ & S 3 & B 6 & BS & HSBY-372 & 61.97 & 52.88 & 80.13 & 10.66 & 48.93 & 13.05 & 4.04 & 11.19 & 1.46 & 8.99 & 2.02 & 5.76 & 0.75 & 4.49 & 0.67 & 245.01 & 5.94 & 1.66 & 0.78 & 30.75 & 1.38 \\
\hline 102.4 & $\mathrm{I}\left(1^{\mathrm{st}} \mathrm{M}\right)$ & $S$ & B & D & 371 & 34.76 & 20.38 & 27.16 & 4.14 & 20.58 & 4.80 & 1.34 & 4.92 & 0.66 & 4.36 & 0.97 & 2.94 & 0.38 & 2.25 & 0.33 & 95.21 & 4.66 & 1.37 & 0.68 & 36.00 & 1.56 \\
\hline 101.3 & $\mathrm{I}\left(1^{\mathrm{st}} \mathrm{M}\right)$ & S 3 & B 6 & BS & HSBY-370 & 122.61 & 58.49 & 51.88 & 16.02 & 81.22 & 20.22 & 4.31 & 19.77 & 2.81 & 19.09 & 4.42 & 14.76 & 2.11 & 14.40 & 2.19 & 311.69 & 2.92 & 1.07 & 0.39 & 27.73 & 2.35 \\
\hline 51.1 & $\mathrm{I}\left(1^{\mathrm{st}} \mathrm{M}\right)$ & $\mathrm{S} 2$ & B 4 & BS & HSBY-324 & 21.61 & 39.90 & 74.18 & 10.20 & 42.14 & 6.80 & 1.05 & 4.86 & 0.62 & 3.68 & 0.77 & 2.53 & 0.37 & 2.67 & 0.41 & 190.17 & 10.96 & 0.90 & 0.85 & 28.24 & 1.12 \\
\hline 48.6 & $\mathrm{I}\left(1^{\mathrm{st}} \mathrm{M}\right)$ & S 2 & B 4 & BS & HSBY-318 & 13.87 & 75.21 & 125.31 & 14.98 & 58.65 & 10.01 & 2.26 & 5.35 & 0.56 & 2.86 & 0.56 & 1.84 & 0.27 & 2.10 & 0.34 & 300.28 & 20.66 & 1.48 & 0.86 & 24.92 & 1.25 \\
\hline 23.4 & $\mathrm{I}\left(1^{\mathrm{st}} \mathrm{M}\right)$ & $\mathrm{S} 2$ & B 3 & SR & HSBY-307 & 13.59 & 11.81 & 16.82 & 2.09 & 9.06 & 2.96 & 1.06 & 2.11 & 0.30 & 1.90 & 0.41 & 1.28 & 0.19 & 1.18 & 0.18 & 51.35 & 5.80 & 2.09 & 0.77 & 33.19 & 1.46 \\
\hline
\end{tabular}


Table 8 The correlation between of Se, Al, Ti and Th of anomalous Se-enrichment samples of the LFm, southern Shaanxi Province, China.

\begin{tabular}{|c|c|c|c|c|c|c|}
\hline Member & n. & & Se & Al & $\mathbf{T i}$ & Th \\
\hline \multirow{4}{*}{$\mathrm{IV}\left(4^{\text {th }} \mathrm{M}\right)$} & \multirow{4}{*}{$\mathrm{n}=5$} & Se & 1 & -0.751 & -0.75 & 0.753 \\
\hline & & Al & & 1 & $.995 * *$ & -0.217 \\
\hline & & $\mathbf{T i}$ & & & 1 & -0.21 \\
\hline & & Th & & & & 1 \\
\hline \multirow{4}{*}{$\mathbb{\mathbb { I }}\left(3^{\mathrm{rd}} \mathrm{M}\right)$} & \multirow{4}{*}{$\mathrm{n}=9$} & Se & 1 & 0.492 & $.845^{* *}$ & 0.286 \\
\hline & & Al & & 1 & $.835 * *$ & $.858 * *$ \\
\hline & & $\mathbf{T i}$ & & & 1 & 0.591 \\
\hline & & Th & & & & 1 \\
\hline \multirow{4}{*}{$\mathbb{I}\left(2^{\text {nd }} \mathrm{M}\right)$} & \multirow{4}{*}{$\mathrm{n}=4$} & $\mathrm{Se}$ & 1 & 0.506 & 0.352 & 0.584 \\
\hline & & Al & & 1 & $.973 *$ & $.994 * *$ \\
\hline & & $\mathbf{T i}$ & & & 1 & $.961 *$ \\
\hline & & Th & & & & 1 \\
\hline \multirow{4}{*}{$\mathrm{I}\left(1^{\mathrm{st}} \mathrm{M}\right)$} & \multirow{4}{*}{$\mathrm{n}=22$} & $\mathrm{Se}$ & 1 & 0.125 & $.435^{*}$ & -0.024 \\
\hline & & Al & & 1 & $.574 * *$ & $.762 * *$ \\
\hline & & $\mathbf{T i}$ & & & 1 & 0.063 \\
\hline & & Th & & & & 1 \\
\hline
\end{tabular}

* Correlation is significant at the 0.05 level (2-tailed).

** Correlation is significant at the 0.01 level (2-tailed). 
Table 9 The correlation between of Se, Cd, Mo, As and S of all the LFm rocks., southern Shaanxi Province, China.

\begin{tabular}{cccccc}
\hline & Se & As & Cd & Mo & S \\
\hline Se & 1 & & & & \\
As & $.461 * *$ & 1 & & & \\
$\mathbf{C d}$ & 0.087 & 0.043 & 1 & & \\
$\mathbf{M o}$ & $.632^{* *}$ & $.491 * *$ & $.133 * *$ & 1 & 1 \\
$\mathbf{S}$ & $.320^{* *}$ & $.595^{* *}$ & -0.037 & $.290^{* *}$ & \\
$\mathrm{n}=464 ; *$ Correlation is significant at the 0.01 level (2-tailed). & & \\
\hline
\end{tabular}


Table 10 The correlation between trace element of anomalous Se-enrichment samples of the LFm, southern Shaanxi Province, China.

\begin{tabular}{|c|c|c|c|c|c|c|c|c|c|c|c|c|c|}
\hline & Se & As & Tl & Ga & Mo & $\mathbf{S r}$ & $\mathbf{B a}$ & $\mathrm{Zn}$ & $\mathbf{V}$ & $\mathbf{P b}$ & $\mathbf{N i}$ & $\mathbf{C u}$ & $\mathbf{S}$ \\
\hline Se & 1 & & & & & & & & & & & & \\
\hline As & 0.244 & 1 & & & & & & & & & & & \\
\hline $\mathbf{T l}$ & $.376^{*}$ & $.334 *$ & 1 & & & & & & & & & & \\
\hline $\mathbf{G a}$ & $.522 * *$ & -0.042 & 0.128 & 1 & & & & & & & & & \\
\hline Mo & 0.255 & $.506^{* *}$ & $.596^{* *}$ & -0.099 & 1 & & & & & & & & \\
\hline $\mathrm{Sr}$ & 0.011 & -0.049 & 0.054 & -0.011 & -0.065 & 1 & & & & & & & \\
\hline $\mathbf{B a}$ & $.738 * *$ & 0.136 & 0.258 & $.878 * *$ & 0.102 & 0.124 & 1 & & & & & & \\
\hline $\mathbf{Z n}$ & 0.061 & -0.02 & 0.16 & -0.03 & 0.084 & 0.015 & -0.029 & 1 & & & & & \\
\hline $\mathbf{V}$ & 0.266 & 0.087 & $.542 * *$ & 0.202 & $.516^{* *}$ & -0.003 & $.306^{*}$ & 0.163 & 1 & & & & \\
\hline $\mathbf{P b}$ & 0.279 & 0.146 & 0.276 & $.492 * *$ & $.423 * *$ & 0.041 & $.630 * *$ & -0.053 & $.506^{* *}$ & 1 & & & \\
\hline $\mathbf{N i}$ & 0.223 & $.302 *$ & $.773 * *$ & 0.011 & $.509 * *$ & 0.058 & 0.117 & $.405 * *$ & $.359 *$ & 0.062 & 1 & & \\
\hline $\mathbf{C u}$ & 0.128 & $.445^{* *}$ & $.585^{* *}$ & -0.184 & $.497 * *$ & -0.07 & -0.055 & -0.023 & 0.292 & -0.061 & $.638 * *$ & 1 & \\
\hline $\mathbf{S}$ & -0.054 & 0.223 & $.529 * *$ & $-.325^{*}$ & 0.194 & 0.014 & -0.183 & 0.009 & -0.044 & -0.039 & $.326^{*}$ & 0.24 & 1 \\
\hline
\end{tabular}

$\mathrm{n}=40$; Correlation is significant at the 0.05 level (2-tailed).

** Correlation is significant at the 0.01 level (2-tailed). 
Table 11 The correlation of $\sum \mathrm{REE}, \mathrm{Ce} / \mathrm{Ce}^{*}, \mathrm{Eu}^{*} / \mathrm{Eu}^{*}$ and $\mathrm{Y} / \mathrm{Ho}$ with $\mathrm{TiO}_{2}$ of anomalous Se-enrichment samples of the LFm, southern Shaanxi Province, China.

\begin{tabular}{cccccc}
\hline & $\sum \mathbf{R E E}$ & $\mathbf{C e} / \mathbf{C e}^{*}$ & $\mathbf{E u} * / \mathbf{E u} \mathbf{u}^{*}$ & $\mathbf{Y} / \mathbf{H o}$ & $\mathbf{T i O}_{\mathbf{2}}$ \\
\hline$\sum \mathbf{R E E}$ & 1 & & & & \\
$\mathbf{C e} / \mathbf{C e}^{*}$ & -0.252 & 1 & & & \\
$\mathbf{E u} \mathbf{u}^{*} \mathbf{E u}^{*}$ & $-.436^{* *}$ & 0.005 & 1 & & \\
$\mathbf{Y} / \mathbf{H o}^{*}$ & -0.3 & $-.414^{* *}$ & 0.035 & 1 & \\
$\mathbf{T i O}_{\mathbf{2}} \mathbf{2}$ & -0.039 & 0.122 & 0.22 & -0.282 & 1 \\
\hline
\end{tabular}

$\mathrm{n}=40$; Correlation is significant at the 0.05 level (2-tailed).

** Correlation is significant at the 0.01 level (2-tailed). 